\title{
COPYRIGHT FOR A SOCIAL SPECIES
}

\author{
Robert E. Suggs*
}

DRAFT OF 12/18/09

* Professor, University of Maryland School of Law. My thanks to participants in the October 2006 Faculty Forum at the University of Maryland School of Law, my colleague, Lawrence Sung, and to Richard Sherwin, and Maxine Grosshans, Alice Johnson, and Nathan Robertson of our library, and my research assistant, Frank McCormick. 


\title{
COPYRIGHT FOR A SOCIAL SPECIES
}

\author{
INTRODUCTION
}

Virtual reality is no substitute for the real thing. Two separated lovers might wonder how their counterparts coped a century ago without cell phones, Twitter, Facebook, email, and live video cams, but not even the most avid "early adopters” would willingly substitute an Internet experience for a lover's physical presence. Humans are social animals, and this is so fundamental to our nature that we often overlook it. While the death penalty is controversialbut still imposed by a large number of state and federal statutes—life in solitary confinement is so barbaric a punishment that it has never been seriously considered for even the most heinous crime. ${ }^{1}$ It is a fate worse than death. A meaningful life requires human society. Expressive culture, ${ }^{2}$ the phenomenon that centrally concerns copyright, uniquely facilitates the human interactions that sustain our social lives. It may have even developed for this purpose. Yet almost imperceptibly we have tolerated, even embraced, technologies that eliminate human interaction from our cultural lives.

Until quite recently bands played music so listeners could dance, and we had no other

\footnotetext{
${ }^{1}$ I exclude from this categorical assertion solitary confinement imposed on prisoners (typically the most dangerous ones) as sanctions for crimes committed after incarceration. I have been unable to find a provision in any jurisdiction, domestic or foreign, that provides for a life sentence in solitary confinement for crimes committed outside of prison. Any regime that would impose such a barbarity is probably so nonchalant in complying with its own laws that it would feel no need to formalize such a practice when adopted.

${ }^{2}$ Throughout this Article I will use the term "expressive culture" or "expressive works" for lack of a better term. The "arts" encompasses too little, failing to unambiguously include history and other factual narratives, like religious or patriotic texts that contain much social meaning. The term "culture" without modifiers is too broad, because it encompasses the material world of housing, clothing, and food, as well as social manners and customs that are not authored in any meaningful sense. In a different context too broad for my purposes, Susan Scafidi uses the term "cultural products" to encompass "cuisine, dress, music, dance, folklore, handicrafts, images, healing arts, rituals, performances, natural resources, or language ...." SUSAN SCAFIDI, WHO OWNS CULTURE? APPROPRIATION AND AUTHENTICITY IN AMERICAN LAW, at ix (2005). Her choice "emphasizes the ongoing nature of the products' creation and the often controversial but significant role of the market in their life cycles.” Id. at X. Siva Vaidhyanathan uses the term "expressive culture" but does not define it. SIVA VAIDHYANATHAN, COPYRIGHTS AND

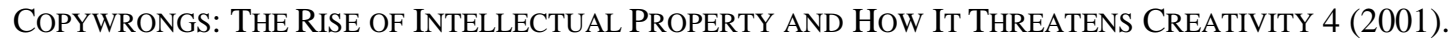


way to hear music except by live performance. Live theater, vaudeville, and burlesque provided the only means to experience comedy and dramas. A century ago expressive culture (music, drama, narratives, and images) was a social experience. ${ }^{3}$ Live actors and musicians performed before live audiences. Storytellers transmitted an oral culture to entertain and entrance social gatherings. Paintings were hung and statues were sited in public spaces where they were seen by groups gathered together for some common purpose. Ceremonies and rituals were celebrated and performed in the cathedrals of great cities and in remote villages. ${ }^{4}$ Until the recent achievement of nearly universal adult literacy, even reading was a social activity. In earlier times, the literate few read out loud to assembled congregants or in family, social, or communal settings. ${ }^{5}$ Only with the invention of recording and playback technologies over the past one hundred years, which enabled the storage and replay in private of aural and visual performances, ${ }^{6}$ did we lose the social dimension to these experiences. Playback technologies have gradually changed the communal, social experience of "live” expressive culture into the private, often solitary, perception of recorded media. What was once experienced only "live" and communally is now experienced that way rarely, if ever.

Just as processed food with its shorter preparation times and longer shelf life is more convenient than fresh food, playback technologies allow us to experience expressive culture at more convenient times and places than live performance. But, just as nutrients are lost when the

\footnotetext{
${ }^{3}$ I use the term "socially experienced" in this Article to designate group or communal experiences (as in an audience or some other collective) in contrast to private or autonomous experiences .

${ }^{4}$ While these examples and many others are drawn from Western culture or history, the analysis is not culturally specific. It is just that Western culture and history is more familiar and accessible to the author and presumably to most readers in the American legal academy.

${ }^{5}$ See infra notes 86-88 and accompanying text.

${ }^{6}$ See, e.g., MARK Katz, CAPTURING Sound: How Technology Has Changed Music 8-9 (2004). Katz discusses "sound recording technology" beginning with the phonograph, in which people for the first time "could listen to the same pieces over and again without change. And they ultimately decided what they were to hear, and when, where, and with whom." Id. at 9 .
} 
food industry transforms whole grains and fresh fruits and vegetables into convenience foods (and nutritionists still have only limited understanding of what is lost), something vital disappears from our culture when technology eliminates the human interaction between performer and audience. And we have been missing it for so long that its absence has become normal. Even so, does it matter?

The answer to this fundamental question depends upon the purposes served by expressive culture. If, as some believe, expressive culture arose as merely pleasurable byproducts of neural networks that evolved for other purposes, ${ }^{7}$ then it probably does not matter. Others argue ${ }^{8}$ that our cognitive capacity both to create and experience art evolved because this trait strengthened social bonds, conferring advantages in domains from reproduction to military defense. The disciplines most concerned with investigating these phenomena, anthropology and psychology, have reached no consensus on this question. They do agree that the skills necessary to create and maintain expressive culture are costly. ${ }^{9}$ Even today in our affluent societies with our devotion to self-improvement, few can play musical instruments, dance, draw, or tell stories well enough to entertain or amuse others. In the ancestral hunting and gathering bands in which human kind evolved, subsistence was marginal and physical survival always tenuous, yet wherever humans eked out a living, they still engaged in these costly pursuits. ${ }^{10}$ How likely is it that coincidentally

\footnotetext{
${ }^{7}$ See STEVen Pinker, How the Mind Works 521-65 (1997) [hereinafter Pinker, How THE Mind Works].

${ }^{8}$ See, e.g., Robin DunBar, GRoOMing, Gossip, AND the EVOLUTION OF LANGUAGE 142-48 (1996) (suggesting that song and dance help to keep large groups that "emerging humans needed for their survival” from fragmenting); id. at 182 (citing cognitive scientist Geoff Miller for the suggestion that artistic skills evolved to charm and hold on to prospective mates); Daniel J. Levitin, This Is Your Brain on Music: The SCIENCE OF A Human ObSession 241-61 (2006). See also infra notes 70-73 and accompanying text.

${ }^{9}$ See DUNBAR, supra note 8, at 143 (“[S]ong and dance . . . are both very expensive activities to perform.”); PINKER, HOW THE Mind WORKS, supra note 7, at 522 ("The very uselessness of art that makes it so incomprehensible to evolutionary biology makes it all too comprehensible to economics and social psychology. What better proof that you have money to spare than your being able to spend it on doodads and stunts that don't fill the belly or keep the rain out but that require precious materials, years of practice, a command of obscure texts, or intimacy with the elite?").

${ }^{10}$ See, e.g., Steven Mithen, The Prehistory of the Mind: The Cognitive Origins of Art, Religion AND
} 
all human societies allocated their scarce resources to these activities if they did not enhance their survival?

Too little is known to resolve this question. We cannot conclude with confidence that expressive culture arose only as a fortunate and nonessential byproduct of another adaptive phenomena and that it has no independent significance. Neither can we safely conclude that it once enhanced survival but no longer does. ${ }^{11}$ We can only speculate (as I do) that if expressive culture provides major adaptive benefits to human society, then a fundamental change in the way we experience and create it - from communal and live to solitary and recorded - may have serious unanticipated consequences. If subsequent evidence does establish the evolutionary significance of expressive culture, then, as with issues of global warming and human influence on climate, it would be tragic if copyright policy contributed to thwarting its most essential role.

Since we roamed savannahs in ancestral hunting bands, the way we experience and create culturally expressive works has changed greatly. As the scale of human societies has grown, these practices have become far more specialized. Agriculture, cities, long distance trade, and the industrial and information revolutions have tended to make expressive culture more elaborate. But recording and playback technologies ${ }^{12}$ in the past one hundred years have worked a more fundamental change than anything before. Technology has divorced human interaction from expressive culture.

The advent of digitalization and the Internet, the technologies that allow us to store

SCIENCE 156-57 (1996) ("The archaeological record shows us that Stone Age art is not a product of comfortable circumstances - when people have time on their hands; it was most often created when people were living in conditions of severe stress. The florescence of Palaeolithic art in Europe occurred at a time when environmental conditions were extremely harsh around the height of the last ice age.” (citations omitted)).

${ }^{11}$ See Brian Leiter \& Michael Weisberg, Why Evolutionary Biology Is (So Far) Irrelevant to Law 13-15 (Oct. 17, 2007) (unpublished manuscript), available at http://ssrn.com/abstract $=892881$.

${ }^{12}$ Printed books record narratives; photographs record images; movies, television, and DVDs record dramas and comedies; and several different technologies record music. 
cultural works and replay them anytime and anywhere, has further accelerated this change.

Together, by permitting nearly costless reproduction and distribution, they pose a major challenge to the copyright regime. These symbiotic technologies have provoked a contentious debate about the need to reconfigure that regime. Much of the academic critique of copyright has focused on the growing propertization of what originally began as a temporary fourteen year exclusive license limited to any “map, chart, book or books” and applicable only to "printing, reprinting, publishing and vending” ${ }^{13}$ such works. ${ }^{14}$ Principal concerns have centered on the ever lengthening term of copyright, ${ }^{15}$ the expanding scope of media covered, as well as the change in 1976 to the automatic grant of copyright upon fixation from the earlier requirement of publication with scrupulous compliance with highly technical notice provisions. ${ }^{16}$ While I share these concerns, this existing literature accepts the treatment of expressive culture as primarily an economic phenomenon. In contrast, this article urges that we should view this aspect of human society as predominantly a social phenomenon.

Another body of work, somewhat tangential to discussions of copyright policy but deeply engaged with it, does consider some social aspects of expressive culture, but it focuses on the social potential of a networked cyberspace. It warns that expanded and assertive copyright will

\footnotetext{
${ }^{13}$ Act of May 31, 1790, ch. 15, § 1, 1 Stat. 124, 124 (repealed 1831). The first statute also provided for a fourteen year renewal term. Id.

${ }^{14}$ See Robert A. Gorman \& JANE C. GinSBURG, COPYright 75-300 (7th ed. 2006); InTELLECTUAL Property StORIES (Jane C. Ginsburg \& Rochelle Cooper Dreyfuss eds., 2006); LAWRENCE LESSIG, FrEe CulturE: The NATURe AND Future OF CREATIVITy (2004); Jessica LitMan, Digital Copyright (2001).

${ }^{15}$ See Eldred v. Ashcroft, 537 U.S. 186 (2003) (upholding parity of increased copyright duration in both future and existing works provided by the 1998 Copyright Term Extension Act that extended term length to "life-plus-70years" after the author's death).

${ }^{16}$ See LESSIG, supra note 14, at 116-73 (detailing the vast domain of interests protected by copyright law and concluding that "[t]he property right that is copyright has become unbalanced, tilted toward an extreme"); LiTMAN, supra note 14, at 17. See also ZORINA KHAN, THE DEMOCRATIZATION OF INVENTION: PATENTS AND COPYRIGHTS IN American EConomic DeVelopment, 1790-1920, at 313-14 (2005); Jessica D. Litman, Copyright, Compromise, and Legislative History, 72 CORNELL L. REV. 857, 901 n.275 (1987).
} 
stifle both the development of new technologies and new social practices. ${ }^{17}$ It celebrates the new interactive dynamism of digital networked technology, especially in comparison with the midtwentieth century’s static and passive experience with analogue technologies. ${ }^{18}$ From a social perspective, contemporary massive multiplayer online games might create a richer social experience than the passive television watching of a decade or two ago, but neither compares well to an even earlier era's sandlot ball games.

Virtual reality, to the extent its ease and ubiquity threatens to replace physical communion and interaction, represents from the perspective of this paper not an exciting new wonder but a noxious technological hazard. This is not to deny that digital networks enhance work place productivity and create previously unimaginable information sharing and collaborative work possibilities, but my concern is with human interaction as an evolved biological phenomenon. However rapidly technology advances, the human organism’s biologically driven responses evolve at a glacial pace and cannot match the current pace of technological innovation. To the extent that evolved social needs rely upon expressive culture, copyright is one of the most important tools, acting as a sort of automotive transmission, to mediate between the fast spinning gears of technological change and the creeping changes in the biologically based needs of our social species.

If the technology that now delivers expressive culture also impedes its adaptive purpose by degrading our social experience, then this has occurred at a dangerous time. The past century's rapid urbanization and industrialization has transformed much of the world's culture and separated us from the stable cultures developed over millennia as hunter gatherers, farmers, and herders in small villages and extended family communities. Human societies everywhere

\footnotetext{
${ }^{17}$ See, e.g., LESSIG, supra note 14, at 7-9.

${ }^{18}$ See id. at 35-38.
} 
have somehow coped with the psychological and social stresses of such rapid and unprecedented change. Until the most recent era, human societies changed very slowly and incrementally. ${ }^{19}$ Almost all the existence of anatomically modern human was spent in ancestral hunting and gathering bands..$^{20}$ Humans had millennia to adjust to the agricultural revolution and its settled patterns of living and attachments to specific territories. We have experienced no evolutionary precedent for the continuous innovations instigated by modern technologies of transportation and communication—-for our resulting mobilization into highly specialized and very large work bureaucracies or socio-political organizations like nation states—and the resulting social and psychological stresses created. These developments in our society, family relationships, and social roles have occurred over mere decades. The rapid pace of such changes is evolutionarily unprecedented, and we have only our culture, especially expressive culture, to help us cope and maintain social cohesion. To alter fundamentally the social environment in which we humans both create and experience expressive culture probably poses unknown but significant risks. Copyright policy has failed to consider this aspect, but this neglect nevertheless shapes the way we create and experience our culture.

To discuss copyright reform without some consideration of the possible evolutionarily adaptive purposes served by humankind's universal commitment to the creation and experience of culturally expressive works leaves that discussion incomplete. Clear proof of an adaptive purpose is lacking, but even assuming that the contrary is ultimately shown, the changes in the way we experience our culture have been too momentous to allow them to pass without remark or discussion. Technology has fundamentally altered our perception and experience of expressive culture, and the implications for the legal doctrines of copyright come naturally

${ }^{19}$ See, e.g., DUNBAR, supra note 8, at 69-70.

${ }^{20} \mathrm{Id}$. 
within that discussion. This paper attempts to start that project.

\section{A Misguided Economic Focus}

Heretofore, academic commentary on copyright has sought to find the ideal mix of economic policies among those implicit in the Constitution’s Copyright Clause, ${ }^{21}$ to strike the proper balance between the burden placed on the public by copyright's limited monopoly grant and the incentive that grant provides to authors to ultimately enrich the public domain. An enriched public domain, freely available to all, supplies subsequent authors with enhanced raw materials from which to construct further creations, thereby promoting the progress of "science.,"22 This tension between monopoly protection and free access plays out even at the level of the individual author: "[E]very author is both an earlier author from whom a later author might want to borrow material and the later author himself. In the former role, he desires maximum copyright protection for works he creates; in the latter, he prefers minimum protection for works created earlier by others. ${ }^{23}$

Whether we conceive of copyright as a system of economic incentives or, alternatively, as a bargain between authors and the public, a temporary monopoly grant from the public in return for the authors' creations, ${ }^{24}$ scholars conduct the policy and legal debate surrounding copyright primarily, if not exclusively, in economic terms. The constitutional text authorizing copyright implies economic considerations. The cultural works at the core of copyright are

\footnotetext{
21 “To promote the Progress of Science and useful Arts, by securing for limited Times to Authors and Inventors the exclusive Right to their respective Writings and Discoveries ....” U.S. CONST. art. I, § 8, cl. 8.

22 “'Science' at that time [1787] was understood to mean 'knowledge,' not just the disciplines deemed to be science nowadays (e.g., chemistry, biology, and physics).” Pamela Samuelson, The Story of Baker v. Selden: Sharpening the Distinction Between Authorship and Invention, in InTELLECTUAL Property STORIES, supra note 14, at 159, 174 n.96 (citing Baker v. Selden, 25 L. Ed. 841, 841 (1880)).

${ }^{23}$ William M. Landes \& Richard A. Posner, An Economic Analysis of Copyright Law, 18 J. LEgAL STUD. 325, 333 (1989).

${ }^{24}$ See LiTMAN, supra note 14 , at 16-17.
} 
created, copied, distributed, publicly displayed, and publicly performed. Because these activities require the consumption of scarce resources, economic considerations play a significant role in copyright policy.

Yet the largely exclusive focus on the economics of copyright has caused us to neglect the more important social dimension. We also experience copyrighted works, ${ }^{25}$ and we value our core cultural works in proportion to the intensity of the experience they engender. Yet despite technology's transformation of our experience of these works in the past one hundred years, little debate has occurred about its consequences for copyright policy, our society, or human relationships.

Americans look to the numbers — of revenues, of exports - to gauge the strength of the arts and our national cultural policy. We measure government support for the arts by the amount of public funding allocated to them, but our society’s culture relies for its health far more upon our legal regime, especially the Copyright Act (Act). ${ }^{26}$ That Act creates the system of property rights that influences the creation of virtually all the expressive works that comprise American culture. To measure the quality of the Act's contribution to the health of our expressive culture—good or bad, efficient or inefficient—analysts and commentators typically look to either the sheer number of works created or the aggregate revenues ${ }^{27}$ their distribution and sale generate. This is a serious mistake.

Neither figure accurately tallies our cultural vitality; they merely calibrate the economic

\footnotetext{
${ }^{25}$ My concern throughout is with the core culturally expressive works of the conventional arts and not thinly copyright protected factual works of utilitarian character.

${ }^{26}$ General Revision of Copyright Law, Pub. L. No. 94-553, 90 Stat. 2541 (1976) (codified as amended in scattered sections of 17 U.S.C.).

${ }^{27}$ Aggregate revenues totaled $\$ 441.4$ billion in 2002. See CONG. Budget OfFICE, Copyright IssuES IN DigitAL MEDIA 4 (2004), available at http://www.cbo.gov/ftpdocs/57xx/doc5738/08-09-Copyright.pdf.
} 
health of the business firms in the copyright industries. ${ }^{28}$ Nothing clearly connects the two. For instance, pornography, a major industry, generates $\$ 9$ billion annually from hard core videos, cable programming, and magazines, an amount as large as Hollywood's domestic box office revenues. ${ }^{29}$ Internet pornography may add another $\$ 12$ billion, ${ }^{30}$ and these are just domestic revenues. Do such sizable revenues demonstrate the strength or weakness, the vitality or corruption of our visual culture? How should we count the frequently denigrated sexually titillating and violent, but nonetheless highly successful, programming of ordinary network and cable television? Economists have already warned that mediocre works with sufficient marketing muscle can crowd out works lacking similar financial support, ${ }^{31}$ including undoubtedly some unrecognized masterpieces.

The very large scale of firms within the copyright industries may itself create problems. The current giant media conglomerates that dominate their industries have huge marketing resources and pursue vertically integrated business strategies involving content ownership, production, and final distribution to the consumer, ${ }^{32}$ so that independently produced content by firms lacking access to similar distribution channels and exhibition venues may fail to reach an

\footnotetext{
${ }^{28}$ The core copyright industries are 1) Publication of Newspapers, Periodicals, Books, etc. (\$143.4 billion); Software Publishing ( $\$ 89.4$ billion); Cable Broadcasting ( $\$ 80.7$ billion); Motion Picture and Video (\$61.7 billion); Radio and Television Broadcasting (\$52.3 billion); and Sound Recording and Music Publishing (\$13.9 billion). Id. (citing the U.S. Census Bureau, Service Annual Survey: 2002 (2004)). These data do not reflect pirated works, but they do reflect some double counting as licensed broadcasts of music and movies would be counted in both the producing and broadcasting industries. Id.

${ }^{29}$ Karyn L. Barr, Crib Sheet: Porn Industry 101 - Look Inside the Industry’s 100-Year History, ENT. WKLY., May 7, 2004, at 17.

${ }^{30}$ Robert MacMillan, Taxing Internet Porn, WASH. Post, Aug. 1, 2005.

${ }^{31}$ See, e.g., Robert H. Frank \& Philip J. CoOK, The WinNer-TAKe-All Society 61-65, 139-41, 189-209 (1995).

But see also Chris Anderson, The Long Tail, WIRED MAG., Oct. 2004, at 171, 172-77, available at http://www.natpe.org/pdf/longtailex.pdf. Anderson argues that the search and storage capabilities made available by digital media, search engines, and the Internet will enable very small quantities of obscure works to be sold over long periods of time, which will greatly reduce reliance on a few "hits" for distributors to achieve commercial success.

${ }^{32}$ See, e.g., World InTELlectual Prop. ORG., WIPO GUIDE ON THE LiCENSING OF COPYRIGHT AND RelAted RIGHTS 52-54 (2004).
} 
audience. Aggregating the revenues generated by an industry structured in this manner conveys little information about cultural vitality.

The economic focus of our measurements of culture masks an even more fundamental discrepancy. Cultural products differ from the tangible goods that economists and statisticians ordinarily count. They differ in more ways than just being nonrival. ${ }^{33}$ Dance, music, narratives, and images - the essential substances of the copyright industries—define us as humans.

Creating these artifacts separates homo sapiens from earlier bipedal hominids ${ }^{34}$ and from our even earlier primate ancestors. ${ }^{35}$ A propensity to create these artifacts evolved tens of thousands of years before the invention of either the markets or the money we now use to measure them. If our culturally expressive works are more than "mind candy," if the circumstances of their creation and experience add more to our social relationships than a topic for discussion around the office water cooler, then merely counting the economic revenues they currently generate may miss the entire purpose of their creation. The way we create and experience these works may have greater significance for human interactions than the numbers of such works we can catalogue and index or the revenues they generate. If so, the current focus for copyright reform misses the point.

\footnotetext{
${ }^{33}$ Music consumption is usually nonrival because one listener's consumption of a music broadcast does not reduce another listener's consumption unlike, for instance, food consumption. In fact, the nonrivalrous consumption by multiple listeners may increase both the consumption and enjoyment of each because their common enthusiasm may lead them to share insights and perhaps even form a fan or music club.

${ }^{34}$ See Mithen, supra note 10, at 151-74.

${ }^{35}$ While the use of tools can be viewed as a critical distinction between man and ape, current research no longer finds such a clear demarcation. Besides, tool use and expressive culture differ in a more fundamental way. See infra note 79 and accompanying text. While constitutional authority for both the copyright and patent grants derives from the same provision, see U.S. ConST. art. I, § 8, cl. 8, copyright differs profoundly from patent. Works at the core of copyright are experienced and are valued for this experience. Technology, the subject of patent, is also experienced, and it has changed the way we experience our world. A great deal is written about how technological innovations change our experience of reality. Science fiction, an entire genre, principally deals with how technology will revolutionize our experience of life, but the experience of technology is peripheral to its primary purpose of utility. Technology solves particular problems and (along a continuum) may be either perfectly transparent to our experience or fundamentally alter it. In contrast the experience of expressive culture, both those that entertain and those that elevate, is the essential justification for their existence and value.
} 
Imagine if we thought of religion in the same way. As with expressive culture, every human society practices religion in some form or another (and in most societies religion spurs major contributions to expressive culture). In most societies religion is a major economic activity. In theocratic societies, religious institutions can dominate political, economic, social, and even military activity. The Catholic Church in medieval Europe exercised power, including military power, that rivaled reigning monarchs, but we do not evaluate the quality and health of spiritual expression and spiritual life by the income or assets of that period's religious institutions. At its zenith of secular power at the beginning of the Renaissance, the European Church had also reached its ebb of spiritual legitimacy. The sale of indulgences and other corrupt religious practices ultimately provoked the Protestant Reformation and the ensuing wars of the Reformation and Counter Reformation. ${ }^{36}$ If cultural expression plays an essential noneconomic role in human society, as I suspect it does, then we seriously distort our society by persisting in evaluating copyright policy by a single economic metric.

Never before has copyright played such a significant role in our society. Digitalization of media has combined with the ubiquity of the World Wide Web to raise popular recognition of the importance of the Copyright Act. Legislators recognize that economically important industries depend on the right mix of exclusive grants and unfettered access to intellectual creations. Their goal, conventionally understood, is to fine tune the Copyright Act and tailor it for globalization and international competitiveness. ${ }^{37}$

36

${ }^{37}$ See S. ReP. No. 104-315 at 4 (Copyright Term Extension Act) ("The purpose of the bill is to ensure adequate copyright protection for American works in foreign nations and the continued economic benefits of a healthy surplus balance of trade in the exploitation of copyrighted works.”). 
Digitalization and the internet pose an unprecedented challenge for copyright. ${ }^{38}$ Some argue that these factors erode the justification for some aspects of the copyright monopoly. ${ }^{39}$ Since this potent combination makes the reproduction and distribution of digitized works nearly costless, the implicit economic subsidy provided by copyright's grant of a temporary monopoly to compensate for these costs becomes unnecessary. In the Internet age, a few mouse clicks creates and distributes essentially free copies. The massive printing presses and dingy warehouses and loading docks of previous eras and all the labor and capital they entailed have become obsolete. Since reproduction and distribution of digitized works no longer require such investments, fewer of the intermediaries between authors and their audiences need the benefits of the copyright monopoly. In the aftermath of such revolutionary change, we have a rare opportunity to rethink copyright policy, perhaps radically.

Wide agreement also exists that for at least the last century, the affected copyright industries have largely supplanted the congressional role in the formulation of copyright policy and legislation. ${ }^{40}$ Each copyright industry has sufficient political influence to stymie congressional action unless proposed legislation satisfactorily addresses its specific concerns. Once the stalemate has persisted long enough (a quarter century in the case of the 1976 Act), a frustrated Congress has allowed the affected industries to draft the needed legislation and then

\footnotetext{
38 "Uses of computer technology—such as digitization—and communications technology—such as fiber optic cable - have had an enormous impact on the creation, reproduction and dissemination of copyrighted works. The merger of computer and communications technology into an integrated information technology has made possible the development of the National Information Infrastructure which will generate both unprecedented challenges and important opportunities for the copyright marketplace.” INFO. INFRASTRUCTURE TASK FORCE, INTELLECTUAL PROPERTY AND THE NATIONAL INFORMATION INFRASTRUCTURE: THE REPORT OF THE WORKING GROUP ON INTELLECTUAL PROPERTY Rights 7 (1995), available at http://www.uspto.gov/web/offices/com/doc/ipnii/. ${ }^{39}$ See Raymond Shih Ray Ku, The Creative Destruction of Copyright: Napster and the New Economics of Digital Technology, 69 U. CHI. L. REV. 263, 267, 264-69 (arguing that "the assumption that digital works are entitled to copyright protection is no longer warranted.").

${ }^{40}$ See LiTMAN, supra note 14, at 35-63.
} 
blessed it by enactment. ${ }^{41}$ New industries, spurred by emerging technologies and lacking a congressional presence, have had no influence, and the public interest has similarly gone unrepresented in this process. In such a legislative environment, academic theorizing unsponsored by a major copyright industry is unlikely to have practical consequences, but the absence of any chance of immediate influence is also liberating. Without the need to consider the economic concerns of particular industries or technologies, issues of long term relevance to the public can become the central focus of inquiry, and this article attempts to capitalize on that opportunity.

This article consists of two parts. The first part begins by examining the possible functions expressive culture might play in human societies. Anthropological and other research suggests that expressive culture plays a significant if poorly understood role in the creation and maintenance of social bonds. I It then proceeds to analyze the way technology has changed our subjective experience of expressive culture. For each major media category, I it briefly sketches how our experience has changed and how technology has expunged the social aspects from that experience. I catalogue how the decline of live performance in the major forms of cultural expression and its replacement by recorded media has undermined the social and communal experience of our culture and substituted an isolated and atomistic one. ${ }^{42}$

\footnotetext{
${ }^{41}$ In the current legislative session, the Congress is considering whether to enact a broad public performance right for sound recordings. Rep. Lloyd "Ted" Poe (R - Texas) "was one of the [House Judiciary] committee members who pleaded with the stakeholders to come to agreement themselves and avoid having Congress impose terms of a performance right.” NAB Witness Resists Pleas to Enter Talks On Recording Artist Performance Bill, PATENT, TRADEMARK \& COPYRIGHT LAW DAILY, Mar. 12, 2009, http://news.bna.com/ptdm/PTDMWB/split_display.adp?fedfid=11656916\&vname=ptdbulallissues\&fn=11656916\&j $\mathrm{d}=$ A0B8B8W4N7\&split $=0$.

${ }^{42}$ Social networks, by allowing interactivity, might seem to counter this trend, but only if we view the period of comparison as the recent past. An interactive Internet is still a use of recorded media to experience reality at second hand and still a marked change from the evolutionary use of expressive culture.
} 
Such a momentous change ${ }^{43}$ in an evolved aspect of our species deserves examination rather than unconsidered acceptance, and Part II opens with an assessment of the goals a copyright system should pursue premised upon the social nature of our species and the assumption that expressive culture plays a significant role in our sociability. My analysis then considers how the substitution of recorded media for live performance has drastically changed the original economic balance struck between authors and performers by earlier copyright acts. I then identify revisions in the public performance and derivative work rights that would restore the element of social experience to expressive culture despite recent technological changes. The Act does not require wholesale modification.

The article then weighs the implications of these statutory adjustments for both authors and the copyright industries. In making such an assessment, I contend that the number and ubiquity of live performances, both amateur and professional, provide a greater indication of cultural health than the profitability of particular entertainment conglomerates or the aggregate revenues of the copyright industries and our international balance of trade in cultural goods. Of even greater relevance, the relative ease with which artists and performers can attain a reasonable livelihood indicates progress towards this goal. There is more than a little irony in our present circumstances, hailed as the Information Age; while media firms have grown to become some of our largest corporations, the career of artist or author exists at the economic margins for all but a fortunate few.

Lastly, I examine the claim, made by supporters of expanded copyright property rights, that the current strong copyright monopoly is the essential incentive for creative innovation. On the evidence of the history of African American music, taken as an illustrative example, as well

\footnotetext{
${ }^{43}$ Such changes may even have significant public health implications.
} 
as other evidence, especially the history of innovative works based upon new technologies, I conclude that little historical evidence supports this assertion. Too much creative innovation occurs outside the copyright system to justify strong copyright on such a basis, although copyright remains significant for the marketing and distribution of innovations to a wider public.

\section{Why Do We CREATE EXPRESSIVE CUltuRE?}

All human societies have created expressive works. Every human society ever examined has had music and dance. ${ }^{44}$ Various theories have been offered for these activities, whether as sexual displays like the peacock's tail to indicate individual reproductive fitness, or as objective evidence of strong group cohesion and thus a caution to other groups contemplating attack. For tens of millennia humans have created such works—-long before we created market economies and mediums of exchange—-which now in our myopia we use to measure their significance.

The purposes served by expressive culture in the formation and maintenance of human societies, which for most of our species’ history functioned as small bands of hunter gatherers, had nothing whatever to do with either the economic incentives contemplated by the current copyright system or any bargain between authors and an abstract "public.” In ancestral hunting and gathering bands composed of extended family groups there were no impartial or anonymous economic exchanges; neither were there economic surpluses to be saved or invested. Because everyone knew each other, no "public" existed. There were only kin and strangers, who were viewed warily, even feared and perhaps hated.

When humans eked out an existence in a subsistence economy of hunters and gatherers, expressive cultural works were costly to produce. The practices that produced them arose, long

\footnotetext{
${ }^{44}$ See DunBAR, supra note 8, at 142. But see Rafaela von Bredow, Living Without Numbers or Time, SPIEGEL ONLINE, May 3, 2006, http://www.spiegel.de/international/spiegel/0,1518,414291,00.html (describing unique Amazonian Indian culture with unusual language spoken by population of only 310-350 and lacking creation myth, stories of any kind, and art).
} 
after the appearance of anatomically modern homo sapiens, during the height of the last Ice Age "when environmental conditions were extremely harsh ...."45 The time and effort devoted to specialized skills and practices necessary to produce them make little economic sense, since they appear to provide no immediate survival benefit. They contributed nothing to the direct material needs of these marginal societies, yet everywhere they developed. The same can be said for the other arts—narrative and the visual and plastic arts (sculpture and painting). Artifacts so costly to produce must have made critical contributions to their societies, even if we cannot yet identify them. It is likely that these art-making activities (for lack of a better term) somehow increased the survival chances of group members by fostering group cohesion or enabling the formation of larger groups. ${ }^{46}$

Some have argued that their purpose was to synchronize our emotional moods. ${ }^{47}$ Song and dance also generate "euphoric highs, as well as feelings of happiness and warmth,” and may "generate surges of opiates from the brain ....”48 Music and dance do perform the notable physiological feat of synchronizing the emotional states of those participants engaged in the activity. The release of endorphins during these activities would further cement social bonds and

\footnotetext{
${ }^{45}$ Mithen, supra note 10, at 157. A very recent discovery of what appears to be seashells used as beads has been dated to more than 100,000 years ago, pushing back the threshold of expressive culture (symbolic personal adornment) to a time closer to the emergence of the first homo sapiens. See Marian Vanhaeren et al., Middle Paleolithic Shell Beads in Israel and Algeria, 312 SCIENCE 1785, 1785-88 (2006). Nevertheless, "[n]o other compelling evidence for bead use exists before about $40 \mathrm{ka}$, when beads appear at African, Eurasian, and Australian sites.” Id. at 1785 (citations omitted).

${ }^{46}$ See generally Leda Cosmides \& John Tooby, Cognitive Adaptations for Social Exchange, in THE ADAPTED MiND: EVOLUTIONARY PSYCHOLOGY AND THE GENERATION OF CULTURE 163 (Jerome H. Barkow, Leda Cosmides \& John Tooby eds., 1992), for the argument that the human brain did not evolve as a general purpose, content independent, reasoning mechanism, but instead "evolved a constellation of cognitive adaptations to social life." Id. Their view "is that humans have a faculty of social cognition, consisting of a rich collection of dedicated, functionally specialized, interrelated modules (i.e., functionally isolable subunits, mechanisms, mental organs, etc.), organized to collectively guide thought and behavior with respect to the evolutionarily recurrent adaptive problems posed by the social world.” Id. Modules devoted to expressive culture might be part of the brain's tool kit.

${ }^{47}$ DunBar, supra note 8, at 147 ("The anthropologist Chris Knight has argued that the use of ritual to co-ordinate human groups by synchronizing everyone's emotional states is a very ancient feature of human behavior, and coincides with the rise of human culture and language.”).

${ }^{48} I d$. at 146.
} 
conceivably allow the formation of even larger groups than language. Dunbar argues that these activities strongly contribute to social cohesion. ${ }^{49}$ Plausibly these aesthetic works provided mechanisms of social bonding that our primate ancestors lacked and provide a possible explanation for the ability of early humans to organize and maintain substantially larger groups than nonhuman primates. ${ }^{50}$

Dunbar argues that language and speech developed as a mechanism to increase the number of individuals that could efficiently and effectively bond for purposes of group defense against predators and perhaps other predatory primates. ${ }^{51}$ Our ancestors co-existed and survived competition with many now extinct hominids. ${ }^{52}$ Climate change increased the intermittent woodland and fringes of the savannah, exposing bipedal hominids on the fringes of the forest to large predators. ${ }^{53}$ Only by growing larger and forming larger groups for common defense could they survive in the new environment. ${ }^{54}$

Hominids were an important prey species for many carnivores, and this environmental pressure played a significant role in our evolution. ${ }^{55}$ Despite the view in the popular mind of “man the hunter,” substantial evidence in the fossil record as well as in contemporary field studies of nonhuman primates reveals the large role that predation plays in the lives of the great apes (chimpanzees, bonobos, baboons, gorillas, and orangutans) as well as other primates, up to

\footnotetext{
${ }^{49}$ See id.

${ }^{50} \mathrm{Id}$.

${ }^{51}$ See id. at 148-51.

52 See Donna Hart \& Robert W. Sussman, Man the Hunted: Primates, Predators, And Human EVOLUTION 21-22 (2005).

53 See id. at 75.

${ }^{54}$ See id. at 170-71. While we "undoubtedly would have died if not for group protection,” recent research has demonstrated that "none of the proposed evolutionary adaptations . . . may be useful against certain predators." Id. See also Donna Hart, Humans as Prey, CHRON. REv., Apr. 21, 2006, at B10.

${ }^{55}$ Current thinking in anthropology emphasizes man the hunted not man the hunter. See generally HART \& SUSSMAN, supra note 52.
} 
and including modern humans in the developing world. ${ }^{56}$ The hominid line diverged from the common ancestor shared with chimpanzees some six to seven million years ago, but the evidence for hunting big game dates to only sixty thousand years ago. ${ }^{57}$ Humans lack the ability to masticate and digest substantial quantities of meat without cooking, and the fossil record for the controlled use of fire dates no earlier than four hundred to eight hundred thousand years ago. ${ }^{58}$ Even the earliest stone tools, which were not yet weapons, first appear about 2.3 million years ago, two-thirds of the way along our journey from our common ancestor. ${ }^{59}$ Cultural practices that which increased social cohesion would positively affect survival because "[p]rotection from predation is one of the most important aspects of group-living . . .,60

Our primate relatives form social groups no larger than about fifty individuals. ${ }^{61}$ They maintain social bonds through the practice of grooming, a one on one activity that, while superficially directed to cleanliness and the removal of parasites, releases endorphins within the brain, translating this outwardly hygienic activity into a deeply satisfying mechanism to establish and reinforce the group's social bonds. ${ }^{62}$ Unfortunately, grooming is time intensive, and the maximum time observed devoted to grooming for any group is about twenty percent of available time. ${ }^{63}$ Devoting more time reduces by too much the time available for foraging and other essential activities. ${ }^{64}$ Dunbar theorized that language developed as a more efficient substitute for

\footnotetext{
${ }^{56}$ See id. at 57-63, 84-97, 124-33, 135-37.

${ }^{57}$ See id. at 224-26.

${ }^{58}$ See id. at 230-31.

${ }^{59}$ See id. at 190.

${ }^{60} \mathrm{Id}$. at 245.

${ }^{61}$ See DuNBAR, supra note 8, at 77.

${ }^{62}$ See id. at 21-23, 35-36, 77. Dunbar notes that "[n]ot all primate societies exhibit [grooming] characteristics," id. at 22, and "[a]t least among the Old World monkeys and apes, the time devoted to grooming . . . correlates roughly with the size of the group." Id. at 35.

${ }^{63}$ See id. at 35.

${ }^{64} \mathrm{Id}$.
} 
grooming, allowing a tripling of the social group to about one hundred fifty. ${ }^{65}$

Conversation provides the glue for social bonds, but the critical conversations contain information, not about objective human reality (e.g., how many potential prey frequent the nearby waterhole), but focus on social relationships. Empirical evidence of the content of conversations suggests that even among the highly educated, most conversational content is about social relationships, i.e., gossip. ${ }^{66}$

Absent a consensus on the purpose of the arts or their role in the evolution of our species, ${ }^{67}$ theorizing about possible roles for the arts falls between two polar and now largely antiquated positions. At one extreme, the mind and culture are infinitely malleable, and social engineering can perfect the human species. ${ }^{68}$ The arts represent a contingent outcome of processes unrelated to human biology. Pinker credits the origins of this view to John Locke (1632-1704), calls it the "Blank Slate,” and while blaming it for many of the horrors of the twentieth century, recognizes it as an improvement on the theories of innate ideas and hierarchy of races and classes that it replaced. ${ }^{69}$ At the other extreme lies Darwin's original idea that human music evolved as a courtship display to attract sexual mates much as did birdsong. ${ }^{70} \mathrm{~A}$

\footnotetext{
${ }^{65}$ See id. at 71-79. This number is a frequently occurring size for many human activities; i.e., the standard military unit since ancient times, the extended multifamily group of hunter gatherer societies, and the maximum size of unstructured but effective business organizations (as developed in the management literature), before more bureaucratic forms must be adopted. See id. at 71-77. Dunbar cites in support of this categorical size empirical evidence on the size and dynamics of conversational groups and the number of individuals with whom we can maintain social relationships. See id. at 73-74.

${ }^{66}$ See id. at 123.

67 "The function of the arts is almost defiantly obscure ....” PINKER, HOW the Mind WORKS, supra note 7, at 522.

${ }^{68}$ See, e.g., Steven Pinker, The Blank Slate: The Modern Denial OF Human NATURe 169-73 (2002) (citing, as an example, B.F. Skinner's utopian idea of conditioning and shaping people towards an ideal end). Pinker does not endorse the predominantly "nurture" position and instead argues that "[t]he existence of a human nature is not a reactionary doctrine that dooms us to eternal oppression, violence, and greed. Of course we should try to reduce harmful behavior .... But we fight those afflictions not by denying the pesky facts of nature but by turning some of them against the others." Id. at 172-73.

${ }^{69}$ See id. at 14-29.

${ }^{70}$ Geoffrey Miller, Evolution of Human Music Through Sexual Selection, in THE ORIGINS OF Music 329, 329-30
}

(Nils L. Wallin, Björn Merker \& Steven Brown eds., 2000) [hereinafter ORIGINs]. 
number of contemporary scholars continue to explore this theory. ${ }^{71}$ Some assign a biological role to music ${ }^{72}$ or to both music and dance. ${ }^{73}$ None would appear to argue that the arts play such an essential role in contemporary human society. Somewhere in between we can locate those such as Pinker, who views the arts as merely pleasurable byproducts of neural networks that evolved for other purposes. ${ }^{74}$ Using Pinker's metaphor-the arts are merely “cheesecake.” Because we evolved to crave nutritionally necessary fats in a fat impoverished ancestral environment, fatty desserts like strawberry cheesecake cater to those neural pleasure centers, but evolution never exerted selective pressure on our species through a specific craving for strawberry cheesecake desserts. ${ }^{75}$ Others in the middle ground see a somewhat stronger role for the biological structures of the human brain in shaping the arts through their having evolved to perceive certain literary themes and visual representations pleasurable. ${ }^{76}$

\footnotetext{
${ }^{71}$ See, e.g., id. at 329-60.

${ }^{72}$ See Ellen Dissanayake, Antecedents of the Temporal Arts in Early Mother-Infant Interaction, in ORIGINS, supra note 70, at 389, 389 (suggesting that the biological origins of music did not result from competition or courtship but from the "affiliative interactions between mothers and infants").

${ }^{73}$ Walter Freeman, A Neurobiological Role of Music in Social Bonding, in ORIGINS, supra note 70, at 411, 419-20. Freeman writes:

There is no reason to doubt that [music and dance] give great pleasure and catharsis to those caught up in the communal spirit of the events .... What is at issue is the extent to which feelings of bonding and formation of a neural basis for social cooperation might be engendered by the same neurochemical mechanisms that evolved to support sexual reproduction in altricial species like ourselves, and that might mediate religious, political, and social conversions, involving commitment of the self to a person as in transference, fraternity, military group, sports team, corporation, nation or new deity. The common feature is formation of allegiance and trust.

Id.

${ }^{74}$ See PinKER, HOW THE Mind WORKS, supra note 7, at 524-26 (arguing that "some of the activities we consider most profound are nonadaptive by-products").

${ }^{75}$ See id. at 525.

${ }^{76}$ See EdWARd O. Wilson, ConsiliEnCE: The Unity of KNOWLEDGE 224-32 (1998) (suggesting that our "aesthetic instinct" imposed order on the confusion created from our awareness of the complex forces in our environment); Joseph Carroll, Wilson's Consilience and Literary Study, 23 PHIL. \& LITERATURE 361, 374 (1999) (book review) ("Wilson's thesis about the evolutionary origin of the arts implies that they both depict epigenetic rules and are themselves regulated by such rules. They have an adaptive function .... In this respect, Wilson's views can be contrasted with those of other sociobiological theorists who have either treated the arts in a rather unintelligently reductive way as a form of sexual display or have discounted them as parasitic by-products of other adaptive functions.”); Harold Fromm, The New Darwinism in the Humanities: Part I: From Plato to Pinker, Hudson Rev., Spring 2003; and Harold Fromm, The New Darwinism in the Humanities: Part II: Back to Nature, Again, HudsON REV., Summer 2003 (detailing the shift towards the sociobiology view of the "mind" and the refinement of Pinker's
} 
The strawberry cheesecake metaphor overestimates the likelihood that neural networks evolved for other unknown purposes but could fortuitously allow us to enjoy expressive culture. It overestimates because the metaphor limits itself to our consumption of the arts. It costs little to consume expressive culture, but it costs dearly to produce it. Production beyond the most rudimentary levels requires years of training and dedication. That every human society, even the most marginal, produces a wide and continuous variety of expressive culture strongly suggests that it provides evolutionary benefits.

But even if expressive culture was once more than cheesecake, it may no longer be so. In the developed world predation on humans is so rare that wide press coverage results from every crocodile, bear, or cougar attack. If expressive culture developed to enhance social bonds solely as a defense to animal predation, then its original purpose has become obsolete. Its further significance, as a source of entertainment or pleasure, is limited then to its economic aspects. But if expressive culture serves other purposes, perhaps as strengthening group commitments against disruptive aggression or as a means to moderate conflicts internal to the social group, then an economic tabulation, no matter how thorough, fails to capture its true significance. Fortunately, resolution of this dispute is not necessary for the essential point of this paper. That point is that the change that technology has created in the way we experience expressive culture is pervasive and now unavoidable and has gone unremarked in the copyright literature. It seems fair to assume that since all human societies have developed these cultural practices and artifacts, then they might have more than casual significance for human societies. In this case it would seem prudent to perhaps examine whether - without causing enormous economic dislocation - we can delay or modestly reverse this technologically imposed trend.

views toward the arts as “more deeply connected with being human”). 
Especially given the importance of social relationships to our species, inadvertently removing the social element from this important cultural dimension as a byproduct of technological advancement seems rash.

\section{A. Social Experience and Copyright Policy}

If we permit non-economic considerations to influence copyright policy, then the significance of the copyright industries extends far beyond the size of their revenues or the number of their employees. When we calibrate the importance of electric power generation or steel production, quantitative economic measures may suffice, but the product of the copyright industries, although economically substantial, is not the source of their singular importance. The way we make expressive culture, and more fundamentally the way we experience it, may have greater significance for our society and culture than either the quantity produced or its aggregate cost. The way we produce and experience expressive culture may also influence its quality. And quality is measured not by critical acclaim or by revenues generated, but by the purposes expressive culture served in our ancestral societies, even though as yet we have no yardstick clearly capable of taking that measurement.

Our current measure of the copyright system is dysfunctional. If public health officials measured the nutritional quality of the food consumed by the American population in the same way as copyright, they would not count nutrients, proteins, carbohydrates, and fats, but the revenues generated by food sales. In such a perverse account, one dollar of wheat germ, high omega three fish, or fresh fruits or vegetables would count the same as one dollar of sugar or transfat. Or imagine if policy makers assessing the efficacy of our health care system ignored life expectancy but looked solely to the revenues of hospitals and HMOs. Yet the only measures 
that matter in copyright policy debates are the revenues of the copyright industries.

To concentrate exclusively on economic considerations makes no more sense in copyright policy than it would in family policy. No one would accept as adequate an analysis of family policy that considered only economic factors. We could unquestionably accomplish child care with far greater economic efficiency if newborns were taken at birth from their mothers and placed in central facilities optimized for economies of scale and staffed by trained professionals. This would free parents from the burdens of childcare, sleepless nights, and the time needed to progress from neophyte parents to seasoned ones. We recognize that such an institutionalized arrangement would be monstrous, because far more goes on between parent and child than the economic provision of those services that could be supplied more efficiently by using economies of scale, although we cannot precisely identify and quantify what those factors might be. Institutionalization would eliminate and thwart one of the most important roles of families, forging the emotional bonds required for a healthy psyche and normal cognitive development. Yet our copyright policy, by eliminating any consideration of the social needs of both the consumers and creators of copyrighted works, and focusing exclusively on economic aspects, has adopted just such a policy.

Why should the degradation of the social experience of cultural works concern us? Is not the ease, low cost, and ubiquity of technological reproduction and performance of these works an unmitigated blessing? Given the hazards of nuclear proliferation, global warming, and new and rapidly evolving pathogens, why should the technologies that allow us to enjoy cultural works that entertain and elevate our spirits whenever and wherever we want—without having to arrange and coordinate the activities of a large number of other individuals—give cause for concern. 
If human beings were merely biological computers, rational and comprehensible, there would be no cause for concern, but humans are a product of evolution. We evolved over millions of years as intensely social animals. We are far from rational and are often incomprehensible, even to ourselves. Moreover, we are fundamentally social beings. Our social relationships define us and sustain us. Apart from our relationships to and with others, we have no meaningful existence.

This social foundation to our humanity is even implicit in the Supreme Court's interpretation of our Constitution. While the Constitution prohibits "cruel and unusual punishments, ${ }^{, 77}$ it permits the death penalty. ${ }^{78}$ Countless state and federal statutes create capital offenses, but none impose a life term in solitary confinement. A life divorced from society is too cruel to contemplate. It is worse than being killed.

Experiencing copyrighted works is more than a pleasant diversion for our leisure time; it is fundamental to our humanity as a species and our success as an organism. Consider the anthropological evidence. Among our primate ancestors what separates earlier bipedal hominids from modern humans are grave goods (jewelry and ornaments, i.e. sculpture, buried with the dead), cave paintings, music, dance, and stories (myths and narratives) told and passed down from generation to generation around the campfire. ${ }^{79}$ Cave paintings herald a consciousness that marks us as different (and more evolved) than Neanderthals. Aesthetic works, now the substance

\footnotetext{
${ }^{77}$ U.S. CONST. amend. VIII.

${ }^{78}$ See, e.g., Kennedy v. Louisiana, 128 S. Ct. 2641, 2650 (2008) ("Though the death penalty is not invariably unconstitutional, the Court insists upon confining the instances in which the punishment can be imposed." (citation omitted)).

${ }^{79}$ It used to be thought that using tools was uniquely human, but chimpanzees, bonobos, and even some birds (crows) have been observed to fashion and use simple tools. See Mithen, supra note 10, at 74; see also MARC D. Hauser \& Ted DeWAN, Wild Minds: What Animals Really Think 33-37 (2000). Hominid ancestors to modern humans made stone tools requiring considerable skill. See Mithen, supra note 10, at 119 ("The Neanderthal stone technology from the Near East illustrates the technical sophistication of the Levallois technique.... Indeed, the Levallois method may involve even greater technical skill that [sic] that required to make handaxes." (citation omitted)).
} 
of the copyright industries, have been found in all human cultures everywhere. ${ }^{80}$ We still perform, enjoy, and learn from the dramas of the ancient Greeks and read the poetry of the Classical era. Other cultures have even older works with contemporary relevance.

\section{B. Playback Technologies and the Social Experience}

Various recording technologies, most obviously those used to record and playback music, but also some less obvious ones, have eliminated much of the social experience of our expressive culture. These technologies have made live performance, previously a dynamic social interaction between performer and audience, an increasingly rare event. Until the beginning of the twentieth century, expressive culture necessarily entailed a social experience. Now it rarely does.

1. Cheap Books and Mass Literacy. - Playback technology originated with the printing press. ${ }^{81}$ Earlier, from Homer to anonymous griots, storytellers with prodigious memories performed oral narratives of folk tales, epic poems, and creation myths. ${ }^{82}$ Oral narratives necessarily were performed within a social context of at least two people, a narrator and a listener, and more typically involved a larger number of listeners. ${ }^{83}$ Printing allowed their

\footnotetext{
80 "One of the more intriguing features of human behaviour is the extent to which song and dance feature in our social life. No known society lacks these two phenomena.” DUNBAR, supra note 8, at 142.

${ }^{81}$ Holographic manuscripts did not constitute a playback technology because writing alone did not create a technology of reproduction in multiple copies with declining marginal costs. Holographic manuscripts were too few and too laborious to produce. See Peter K. Yu, Of Monks, Medieval Scribes, and Middlemen, 2006 MicH. ST. L. REV. 1, 3-10 (2006) (detailing the "slow, tedious, and very time-consuming" history of book copying before the invention of the printing press). Cambridge University, founded in 1209, had only 122 books in 1424, when it was already two centuries old. Yu, supra, at 7; see also University of Cambridge: 800 Years, http://www.800.cam.ac.uk/page/168/800-years-of-history.htm (last visited July 31, 2008). It took another half century to reach 330 books. Yu, supra, at 7.

${ }^{82}$ See, e.g., Walter J. Ong, From Mimesis to Irony: The Distancing of Voice, Bull. Midwest Language Ass'N, Spring-Autumn 1976, at 1, 4; see also John D. Niles, Homo NARRANS: The PoEtics AND ANTHropology of ORAL LITERATURE 1-32 (1999) (centering his study of storytelling around his theme that "oral narrative is and for a long time has been the chief basis of culture itself").

${ }^{83}$ See Ong, supra note 82, at 4, 9 (emphasizing the participatory and integrative nature of public oral performance).
} 
replacement by books, a relatively cheap, portable device, immune to memory lapses, disease and old age, which could be reproduced in practically infinite copies, could travel anywhere, and could simultaneously reproduce their contents all over the world. Rather than experiencing narratives in a communal setting with others eager to listen, books allowed literate individuals to experience narratives at their own convenience, as solitary individuals, and for those with access to modern libraries, in far greater number and variety than even a collection of storytellers could ever muster. Weighed against these advantages are what was lost—-the interactive conversation with and among the story teller's audience.

Before the advent of mass literacy in the nineteenth century, ${ }^{84}$ reading could be a solitary experience for only the literate few. Even among the literate, the small number of available books meant that readers could discuss what they had read with the assurance that others, were familiar with the same works. ${ }^{85}$ With the current proliferation of choices, we need structured reading groups to assure by explicit commitments that we will have read works in common. Until nearly one thousand years ago (at least as far as the Western experience is concerned) the social experience of text had not changed since the classical era, and then a minor departure occurred. It began with the innovative practice of silent reading. ${ }^{86}$ Until then to read, even when alone, was to sound out loud the text, ${ }^{87}$ preserving both the oral tradition and at least a

\footnotetext{
${ }^{84}$ See, e.g., Carl F. Kaestle, The History of Literacy and the History of Readers, 12 REV. RES. EDUC. 11, 20 (1985) (noting that "[b]etween 1600 and 1900 the countries of Western Europe moved from restricted literacy to mass literacy, with immense consequences for education, social relations, and communications").

${ }^{85}$ For an example of the small size of even university libraries during the Middle Ages, see Yu, supra note 81. ${ }^{86}$ See Alberto Manguel, A History OF ReAding (1996). In a discussion of St. Augustine and reading, Manguel concludes that "[t]he implication is that this method of reading, this silent perusing of the page, was in his time something out of the ordinary, and that normal reading was performed out loud. Even though instances of silent reading can be traced to earlier dates, not until the tenth century does this manner of reading become usual in the West.” Id. at 43 (citing previous scholarship on this point). The main text devotes several pages to this general theme of the evolution of silent reading and the tension between marks on a page and their sounds as spoken. See id. at 41-53. I thank the good fortune of a serendipitous encounter with a former colleague, David Luban, for the discovery of this source.

${ }^{87}$ Id. at 45 ("Written words, from the days of the first Sumerian tablets, were meant to be pronounced out loud, since
} 
vestige of the social experience of the work. Words as text alone did not exist without their sounds. Those few who were literate read aloud to those who were not; and until quite recently reading aloud was a common form of entertainment, ${ }^{88}$ and dramatic readings were a significant leisure activity even among the literate. ${ }^{89}$ The subsequent development of printing then combined with the practice of silent reading produced the first of the "playback technologies" that stripped social experience from the experience of cultural works.

2. Images. - Even after printing and mass literacy developed and greatly reduced the social experience of narratives, we still experienced other types of cultural works collectively. For a time, we could only produce drama and music and dance in groups, and without storage media, we could only experience them in live performance, but purely visual works, especially static images, were soon revolutionized by technologies of reproduction.

Visual works, within the Western tradition, were experienced in a social environment within public spaces, whether pagan temples or Christian cathedrals, the public rooms of palaces of kings and princes, or the public squares of the towns. In the European tradition these media trace their origins back to the religious artifacts and images used in the rituals of the medieval church. $^{90}$ Images, whether two dimensional stained glass windows and painted frescos, or three dimensional statues carved in wood and stone, illustrated religious stories and Biblical parables

\footnotetext{
the signs carried implicit, as if it were their soul, a particular sound.”).

${ }^{88}$ See, e.g., STEVEN ROGER FISCHER, A HISTORY OF READING 274-75 (2003).

${ }^{89}$ See id. at 275 ("Authors' public readings of their works flourished in the nineteenth century to a degree that had not been experienced in Western Europe for nearly two thousand years.”).

${ }^{90}$ Michael Camille, Seeing and Reading: Some Visual Implications of Medieval Literacy and Illiteracy, ART HISTORY, Mar. 1985. "This group before the mosaic, wall painting or stained glass would have perceived these works of art, not in terms of individual response, but as a choric or mass one. ... Reading in the medieval world was often, as Susan Noakes has shown, 'a community experience in which the interpretation of the text any single listener or reader developed was the product, not of his understanding of the text alone, but of a combination of questions and insights supplied by others.'” Id. at 32-33 (citing Susan Noakes, The Fifteen Oes, the Disticha Catonis, Marculfius and Dick, Jane, and Sally, U. CHI. LiBr. SOC’Y BulL., 1977, at 10-11).
} 
and served as backgrounds and provided context and subject matter for sermons and homilies. ${ }^{91}$ One can easily imagine new paintings as the prized new possessions of congregations and the frequent subject of conversations among congregants. Adults might explain them to children, or among themselves children might make their own sense of new and stimulating images.

With the consolidation of temporal power by monarchs and princes in the precursors of European nation states, rulers displayed their images in public squares and palaces to demonstrate their grandeur and fitness to reign. ${ }^{92}$ Paintings and sculptures in town halls and squares solidified the power of local notables. ${ }^{93}$ Rulers commissioned art, not for private aesthetic consumption, but for this instrumental purpose. These were not like the anonymous portraits that fill our contemporary museums, divorced from context and distant in time or place. These images were of people important to the world of the audience viewing them; ${ }^{94}$ feckless princes, brave commanders, or cruel and arbitrary nobles known to their viewers from their personal experience of military campaigns or taxes to sustain grand palaces. Viewers probably gossiped about whether idealized likenesses captured the true personality; emotions, from scorn to ridicule to admiration, would have fueled their discussions. In the public environments of cathedrals and palaces in with these works were displayed and absorbed, consumption was social or communal. It was felt, like architecture, as much as seen.

Only after the Renaissance did the subject matter of the arts embrace the images and

\footnotetext{
${ }^{91}$ James H. Marrow, Symbol and Meaning in Northern European Art of the Late Middle Ages and the Early Renaissance, 16 SIMIOLUS: NETHERLANDS Q. FOR HIST. ART 150-69 (1986) ("A central task for artists during the high and late middle ages was to provide works of art that functioned in or in association with diverse aspects of the cult, and that were to convey information from the teachings of the church .... [A]rtistic production continued to be dominated by works for use in conjunction with the cult or liturgy, or with other traditional devotional practices ... .’). 
domains of ordinary people. ${ }^{95}$ If our public spaces were filled with images of hereditary office holders, whose decisions affected our families and fortunes over generations, our responses might differ from both the hushed reverence with which we browse museum collections and the tepid comments we make about our friends' choices in coordinating paintings with throw pillows. Instead, graffiti—perhaps even obscene—might best capture our sentiments for such public images.

In the mid-nineteenth century the invention of photography changed image making from a lengthy, highly skilled process, like drawing or painting, which can take hours or even months, to a practically instantaneous one. Early photography, though time consuming, laborious, and skilled compared to current technology, was infinitely faster and required far less skill than the drawing and painting it replaced. Great photography may require great skill, but producing a recognizable image does not. In comparison, drawing or painting a recognizable portrait is a virtuosic performance. Both drawing and painting provide plenty of time for relationships to develop between author and subject or with others visiting the sitter or the artist. Conversation does not interfere with the process and may even help, but photography allows no time for relationships beyond a cursory introduction, since talking, unless chosen as the subject matter, spoils the pose. Modern photography and videography have become so quick and easy that subjects may remain oblivious to the process. To draw or paint a copy of a drawing or painting takes time and considerable skill; in contrast, to make another positive print from a photographic negative is now automated and requires no human effort. Photography transformed image making from a slow relational process in which subject and artist could converse and interact with each other, to a process which reduces the subject to an inanimate object, lacking 
personality, volition, or attributes beyond the contours of the captured image.

Only the plastic, three dimensional arts have yet to experience a playback technology of instantaneous and inexpensive replication, but change may be imminent. Ordinary consumers lack any digital process to reproduce or send objects over the Internet, but for commercial and industrial users three dimensional reproduction has arrived. ${ }^{96}$ 3D printers take computer-aideddesign (CAD) files, often transmitted over the Internet, and through a process involving sprayed plastic particles and glue or ultra violet light and liquid resin baths, build three dimensional objects layer by layer. ${ }^{97}$ The current technology takes one to four hours to complete the process and cannot yet make semiconductors, but some models can already use metal powders fused by lasers to make metal parts with strength comparable to metal castings. ${ }^{98}$ In the near future these machines, by copying each of their parts, may be able to replicate themselves (assembly required). ${ }^{99}$ In comparatively short order this technology will trickle down to consumers.

3. Music Recordings. - The invention of the piano roll at the end of the nineteenth century, followed soon after by the phonograph, changed music from a relational and social experience between performer and audience—and frequently a collective participatory experience - to a solitary one occurring in private spaces. ${ }^{100}$ With headphones and ear buds, music has become a private experience, even in public spaces. And the pace of change continues to accelerate.

The technology that enables us to experience expressive culture as solitary individuals has superseded the social and communal origins of expressive culture. Recording technology

\footnotetext{
${ }^{96}$ See William M. Bulkeley, 3D Printers Reshape World of Copying, WALL StREeT J., Aug. 3, 2006, at B1.

${ }^{97}$ See id.

${ }^{98} \mathrm{Id}$.

${ }^{99} \mathrm{Id}$.

${ }^{100}$ In the early years of phonograph ownership, when listeners sought to link their experience with the elite practice of attending live symphony concerts, "programs were often distributed and proper concert decorum was expected." KATZ, supra note 6, at 57. Some "home impresarios" even prohibited talking during performances. Id.
} 
has made music a solitary and passive activity for the listener, whether the teenager upstairs alone in his room, the commuter in his car, or the jogger with her Walkman and now her Ipod. It was not always so:

Brahms and his contemporaries never heard a note of music unless they were in the presence of someone performing it. One of the consequences of this fact ... was that music-lovers had to seek out music, or make it for themselves. It did not come to them with a press of a button. Music was therefore not just an aural experience, as it has largely become. It was also a matter of physical presence, social interaction, and direct communication between musicians and audience. ${ }^{101}$

Live music concerts include the visual dimension, a significant aspect that recordings

lack. The development of music videos does not compensate for this loss. Music videos, restricted to only the most heavily marketed pop music, rarely, if ever, show actual live concert performances. Instead, they are miniature films of narratives made to accompany the music. Much of the music marketed with music videos could not physically or sonically be performed live as shown, because the visual special effects, sound manipulation, and multiple locations used as settings require the elaborate production techniques of both film and music studios to create. $^{102}$

Beyond the visual dimension of live concerts is the dynamic between performers and audience. ${ }^{103}$ Each responds to the other. Early styles of jazz functioned chiefly as dance music, although even in the absence of dancing, live jazz performances were often featured longer and featured more solos and improvisation than did recorded works. ${ }^{104}$ Improvised jazz responded to the movements and energy of the dancers, and because improvising performers were

\footnotetext{
${ }^{101}$ Robert Philip, Performing Music in the Age OF ReCording 4-5 (2004).

${ }^{102}$ Budgets for the most elaborate music videos can rival those for independently produced feature films.

${ }^{103}$ Robert Philip argues that the repeatability of recordings causes the loss of the element of surprise in music (and other) performances and makes our experience seem stale. See PHILIP, supra note 101, at 244-50. Is this not the loss of the "making special" that Dissanayake argues is the impetus and function of art? See Ellen Dissanayake, The Core of Art: Making Special, J. CAN. Ass’N FOR CURRICULUM STUD., Fall 2003, at 13, 13-38.

${ }^{104}$ KATZ, supra note 6, at 76 .
} 
unconstrained by the three to four minute maximum that the $78 \mathrm{rpm}$ recording technology allowed, live performances differed substantially from recordings. "[B]ands were unlikely to cut a performance short if they sensed the audience would keep dancing, even if that meant playing for unusually long stretches." ${ }^{105}$

Social dancing ${ }^{106}$ has at times been an important social activity. “'In Chicago alone, in 1911, it was calculated that 86,000 young people attended dancehalls every evening—many more than attended movies or pursued any other forms of recreation." ${ }^{107}$ Especially on the Mississippi and its tributaries, dancing to live bands on river excursion boats was a major source of entertainment prior to World War II. ${ }^{108}$ Until music recordings became available, social dancing always entailed a live performance by musicians. During the "Swing" era of the 1930s all the major big bands, including those of Ellington, Basie, and Goodman, toured constantly and played for live dancers. ${ }^{109}$ Social dancing is now largely limited to adolescents and young adults at proms, college mixers, and dance clubs. Few involve live music of the highest professional caliber.

During the nineteenth century the relationship between audiences and classical composers differed from those of contemporary composers. Nineteenth century composers

\footnotetext{
${ }^{105}$ Id. at 74 .

${ }^{106}$ Formal dance concerts, such as ballet, were never participatory. Although the dancers perform to live music, audience members play a passive role, and virtually none takes place without public subsidies in one form or another.

${ }^{107}$ Kathy Ogren, Nightlife, in 3 EnCYCLOPEDIA OF AMERICAN SOCIAL HISTORY (Mary Kupiec Cayton, Elliott J. Gorn \& Peter W. Williams eds., 1993) 1713, 1717 (citing Russell B. Nye, Saturday Night at the Paradise Ballroom; or, Dance Halls in the Twenties, 1 J. Popular Culture 7, 15 (1973)).

${ }^{108}$ See WiLliam HOWLAND KENNEY, JAZZ ON THE RIVER 1-2, 64-87 (2005).

${ }^{109}$ GARY GIDDINGS, VISIONS OF JAZZ 157 (1998) ("Ellington continued on the road playing one-nighters as he composed and recorded the most extensive body of music ever produced by an American.”). ELIJAH WALD, How THE BEATLES DESTROYED ROCK 'N' ROLL 98 (2009) (“[A]ll the bands played dance music, which meant that their primary duty was to get people out on the floor, not to provide a deeply fulfilling listening experience."). "Though by the 1930s some critics were already hailing him [Ellington] as one of America's finest composers, many of his early masterpieces were written during his orchestra's five-year residency at Harlem's Cotton Club, where his job was to provide appropriate music for social dancing and gaudily risque revues.” Id. at 103.
} 
actively sought to exploit the market for amateur musicians. ${ }^{110}$ Before recordings became available the only music readily available was produced by amateurs performing for their own enjoyment and that of their immediate social circles. "Hayden wrote piano trios for the domestic market. Schumann wrote not only virtuoso works but also albums of pieces 'For the Young'.,"111 Brahms wrote more than twenty piano duet arrangements of his chamber and orchestral works. ${ }^{112}$ "Little or nothing is written by major classical composers of the present day for ordinary people to play themselves." ${ }^{113}$

When conductors premiered works unfamiliar to their audiences, they played them differently, using performance techniques (e.g. exaggerated tempo modifications) that sonically "underlined" significant themes to assist their audiences in following changes of mood in new and unfamiliar works. ${ }^{114}$ Audiences were also more interactive. They “almost always” applauded between movements and even during movements to show even greater appreciation. ${ }^{115}$ They would also insist on encores of favorite movements (since prior to recordings they could not hear it again except in another concert) often even before completion of the entire work, and these were routinely performed. ${ }^{116}$ In modern performances, encores are rare except at the end of a concert. ${ }^{117}$

Even what constitutes a live performance has changed in the past century. Live pop concerts may not be what they seem. Many types of popular music cannot be performed truly live. Ostensibly "live” performances include added recorded elements while performers lip

\footnotetext{
${ }^{110}$ See PHILIP, supra note 101, at 7.

${ }^{111} I d$.

${ }^{112} I d$.

${ }^{113}$ Id. at 8.

${ }^{114}$ See id. at 11-12.

${ }^{115} \mathrm{Id}$. at 11 .

${ }^{116}$ See id. at 10-11.

${ }^{117}$ Id. at 10.
} 
synch because the sound effects that create hits often either cannot be reproduced by live musicians or exceed the technical capabilities of celebrity performers. ${ }^{118}$ Acrobatic and exhausting dance routines require that even very talented vocalists lip sync their recordings, because their physical exertions make the breath control achieved in recording studios impossible. ${ }^{119}$ Such “live” performances’ rigidly choreographed routines, light shows, pyrotechnic displays, and special effects cannot be varied to respond to the audience's reception. They cannot maintain a dynamic interchange between performer and audience.

We need to reestablish the bond and communication between performer and audience and among those in the audience. The feedback loop between creator and audience that once was immediate and must have been central to the act of creation is now relegated to a time long after the act of creation, when authors have moved on to other works. ${ }^{120}$ Recording artists spend months sequestered in soundproof studios creating albums. Performers may record their individual contributions in separate studios and transmit them over fiber optic links and never physically meet their co-performers. ${ }^{121}$ Living performers perform with dead ones. Natalie Cole recorded a duet with her father, Nat "King” Cole, long after he died. ${ }^{122}$ A recently released album combined the newly recorded big band of Count Basie (twenty-two years after his passing) with the 1973 vocal recording of Ray Charles. ${ }^{123}$ Frequently, only after their albums are finished, reproduced, and marketed do pop musicians go on the road to tour and first perform their new music in front of live audiences. Only then do the critics weigh in with their reviews

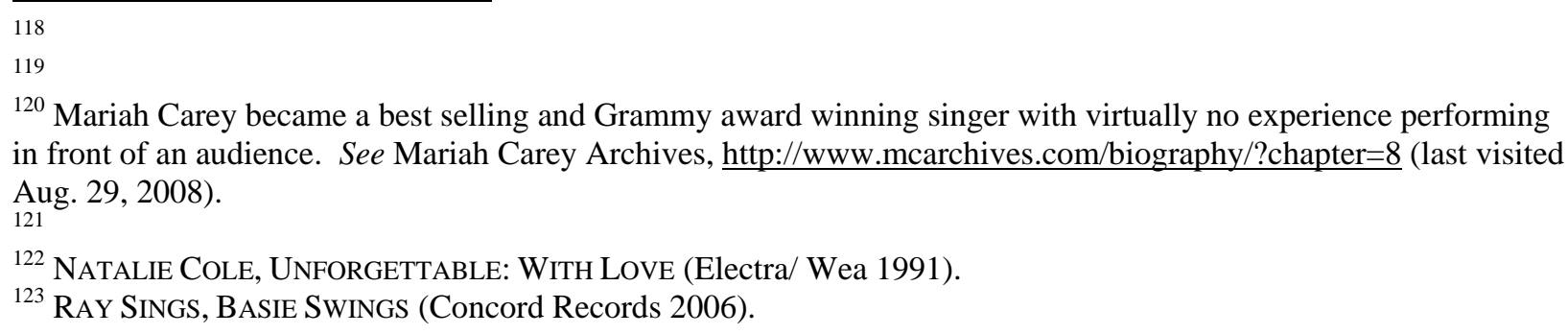
in front of an audience. See Mariah Carey Archives, http://www.mcarchives.com/biography/?chapter=8 (last visited Aug. 29, 2008). 
and the accountants render their verdicts with box office and royalty statements or Neilsen ratings.

\section{Drama, Movies, and DVDs}

Technology has made the most rapid and transformative changes to the dramatic form, and these changes have led to the most radical reshaping of our experience of drama. Technology has permitted the creation of new forms that do not just denude drama of social experience, but with film techniques that have no theatrical counterpart, have developed a new medium. Special lenses provide telescopic close ups or panoramic views. Film editing juxtaposes different points of view or flash backs in time. Special effects realistically portray outer space or the interior of the human body. These techniques have created a new medium, but one devoid of human interaction between performers and audience. This new medium quickly dominated the old, and by the mid-twentieth century live theater had virtually succumbed to motion pictures, which itself soon suffered the onslaught of television, whose disaggregated audience formed an even less social medium.

The decline in social experience is continuous and continuing. Theater had both live performers and a congregated live audience. Movies replaced performers with recordings (films) but still provided the experience of a live congregated audience viewing the film together. (Laughter is infectious.) ${ }^{124}$ Television broadcasts, except for a brief time during its infancy and

\footnotetext{
${ }^{124}$ See Robert D. Putnam, Bowling Alone: The Collapse And Revival of American Community (2000) ("The artifice of canned laughter reflected both the enduring fact that mirth is enhanced by companionship and the novel fact that companionship could now be simulated electronically.”). The aggregated movie audience experience reached its high point in the 1940s when weekly movie attendance peaked at 85 million tickets per week. See Alan Paul \& Archie Kleingartner, Flexible Production and the Transformation of Industrial Relations in the Motion Picture and Television Industry, 47 InDUS. \& LABOR REL. REV. 663, 665 (1994). Current movie attendance, with twice the population, is less than one-third that of sixty years ago. In 2008 weekly ticket sales averaged only 26 million. Motion PiCtURE Ass'N OF AM., THEATRICAL MARKET StATISTICS 4 (2008), available at http://www.mpaa.org/2008\%20MPAA\%20Theatrical\%20Market\%20Statistics.pdf (citing domestic annual
} 
except for sports and special events, are recorded. Television compounds the degradation of the social experience by dispersing its audience to the isolation of individual households. Televisions have become so cheap and ubiquitous that few families even watch together anymore. $^{125}$ Instead each family member watches her own set, eliminating a frequent source of sibling conflict, but also discarding the social experience. With multiple televisions in each household and the increasing number and variety of channels, each viewer can find and watch particularized choices in solitude. Inventions like the video tape player and digital versatile disc (DVD), and services like TIVO and broadband downloads to computers, have further atomized the audience, disaggregating it in time as well as in space. Dispersed audiences find fewer spontaneous occasions to congregate for post-mortem discussions of what they have seen, since network broadcasts no longer synchronize our viewing habits. The hardware itself has begun to limit the social experience of video. A small audience can collect around a television, especially one with a large screen, but how many can comfortably watch the screen of a computer, cell phone, or video Ipod? Private experiences now have largely supplanted social ones for drama too.

Technology has changed the experience of drama for performers as well. Drama developed from religious pageants, initiation rites, and communal ceremonies as a public and collective experience. ${ }^{126}$ Movie making, for those involved, retains something of a social experience. It requires collaborative contributions from many different people and these often take place during months or weeks “on location” in sequestered and emotionally intense working environments far from the familiar homes and routines of the participants. Such an environment

admissions of 1.364 billion).

${ }_{126}^{125}$ See PutNAM, supra note 124, at 224. 
recreates, if only artificially and temporarily, something like the communal and immersive experience of religious and ceremonial ritual in of our ancestral societies. Unfortunately, the technology of film making fundamentally differentiates the experience of those making the film from their audience's experience. The participants’ experience is divorced from their audience’s, not just by time and space, but also by continuity and sequence. Directors do not shoot the many scenes that make up a film in the order in which the film editor will assemble them for the version audiences see. Far more film is shot than makes the final cut; directors shoot multiple takes of scenes until they are satisfied with their actors’ performances, and they may even film alternative versions of plot elements. The experience of making a film is one of disjointed, unconnected segments in contrast to the seamless experience obtained from viewing the final product.

While actors will experience each scene, they will have no sense of the complete drama. Unlike the theatrical performers, who confront and engage the expectations of a live audience, film actors not only have no such audience response to guide them in their own interpretations of the script, but they lack any experience, based upon performance (as differentiated from reading the script), of the work as a whole. The gulf between performer and audience arises from more than just disparity in time and space. It grows from the absence on one side and the presence on the other of narrative order.

\section{Future Trends}

The audience for recorded arts and entertainment dwarfs the audience for live performance. $^{127}$ The most prestigious categories of live performance (symphonies, ballets, and

${ }^{127} 2002$ survey data of the 205 million U.S. adults reveals that about 35 million adults attended at least one musical 
legitimate theater) are cultural dinosaurs that require large public subsidies to survive. ${ }^{128}$ Even these do not reach substantial live audiences compared to those for recorded mediums. ${ }^{129}$ Attendance at such events is reserved for special occasions for all but a tiny minority of the population. ${ }^{130}$ Elite performance groups, like the symphony orchestra, face rapidly aging audiences and an inability to capture younger concert goers. ${ }^{131}$ Perhaps the largest remaining reservoir of live performance comes from popular music groups, but nothing comparable occurs in other cultural forms. ${ }^{132}$ Every major urban area has several live music performances scheduled for each weekend. These range from the intermittent appearance of major acts with national or even international followings to local or regional groups that often lack recording contracts and rely on performance fees for their income. ${ }^{133}$ Sometimes performers perform

play (the most popular performing art) in the previous 12 months, averaging 2.3 performances per year. NAT' $\mathrm{L}$ ENDOWMENT FOR THE ARTS, REPORT No. 45, 2002 SURVEY OF PUBliC PARTICIPATION IN THE ARTS tbls.7-8 (2004) [hereinafter ARTS REPORT No. 45]. This is about 1 in 6 adults. In the same period 25 million adults attended at least one non-musical play, 22 million at least one Jazz performance, 24 million at least one Classical music performance, 8 million attended at least one ballet performance and 12 million attended at least one of some other dance performance. Each attender averaged between 2 and 3 performances per year. Id. If visits to art museums and galleries are also included (and these are not live performances) then fewer than 4 in 10 adults engaged in at least one of these activities each year. Id. at 11 \& tbl.6. In comparison, few Americans spend a single day without watching television or DVD's, listening to music on the radio or other music sources or viewing entertainment on the internet. "On average, TV-watching consumes about half of the total daily leisure time of all Americans ages 15 and older.” NAT'L ENDOWMENT FOR THE ARTS, REPORT No. 47, To READ OR NOT tO READ: A QUESTION OF NATIONAL CONSEQUENCE 38 (2007), available at http://www.nea.gov/research/ToRead.PDF [hereinafter ARTS REPORT NO. 47].

${ }^{128}$ In 1992 the overwhelming majority of classical music groups were tax exempt nonprofits (689- tax exempt; 51taxable). NAT'L ENDOWMENT FOR THE ARTS, NOTE NO. 68, at 1 (1998). In that year classical music groups received $43 \%$ of their revenues from government and private grants. Id. at 4 . Tax exempt dance organizations outnumbered their taxable counterparts in 1992, 275 to 133, and 41\% of their revenues came from government and private grant support. NAT’L ENDOWMENT FOR THE ARTS, NOTE NO. 67, at 1, 4 (1998).

${ }^{129}$ Americans 15 and older average 2 hours and 21 minutes of TV watching weekdays and 3 hours and 6 minutes on weekends and holidays. ARTS REPORT No. 47, supra note 127, at 39 tbl.3C.

${ }^{130}$ ARTS REPORT No. 45, supra note 127, at tbls. 7-8.

${ }^{131}$ Between 1982 and 2002, the percent of adults attending classical music performances declined from $13.0 \%$ to 11.6\%; the average number of performances attended increased slightly between 1992 and 2002 from 2.6 to 3.1 per attender. Of those who attended at least one such performance in the 12 month period ending in August 2002, $30.7 \%$ were younger than 35 and $43.5 \%$ were 45 and older.

${ }^{132}$ See generally Russell SAnjek, PenNies from Heaven: The American Popular Music Business in the TWENTIETH CENTURY (David Sanjek ed., 1996). Vaudeville and burlesque once provided drama, comedy, and music in innumerable venues and throughout the nation. See id. at 33, 57-61.

${ }^{133}$ One burgeoning subspecies of popular music is church based Christian rock music, whose purpose is not to seek 
"live" in only the narrowest sense. ${ }^{134}$ Only jazz and some types of folk and specialized country music persist as music forms with strong live performance traditions unaffected by the electronic enhancements found in most pop concerts, but these comprise only a small share of the music audience and a miniscule portion of the total music experience (including recordings). ${ }^{135}$ Even grand opera, too small to register in our analysis, for some productions now grudgingly embraces electronic amplification. ${ }^{136}$ Comparing the quantitative experience of live to recorded mediums, in only one hundred years music has moved from collective, participatory ensemble music making, oriented around a common repertoire, to uniquely programmed Ipods experienced privately with earbuds even on public streets.

The recent phenomenon of "house concerts" represents an opposing and still very minor trend. House concerts, organized by music fans over the internet, feature professional acoustic musicians in private homes with intimate audiences measured in the dozens. Motivated by their enthusiasm for the performer rather than profit, hosts turn over cover charges as the performer's compensation. With meals and lodging provided by such fans, some performers have managed to arrange national tours from house to house in an underground circuit that ignores zoning ordinances, fire codes, and performing rights organizations. The audience tends to be older, in

commercial success but to bring together a community, perhaps a close cousin of the original purpose of the music created by ancestral societies. See Ben Ratliff, Plugging in to Make a Joyful Noise unto the Lord, N.Y. Times, Nov. 7, 2007, at E1.

${ }^{134}$ See supra notes 118 and 119 and accompanying text.

${ }^{135}$ Jazz recordings held only $1.1 \%$ of the market in 2008, and going back until 1999, never gained more than 3.2\%. Folk recordings are subsumed in the "Other" category, which comprised $9.1 \%$ in 2008, the highest in the years since 1999. Within this category’s 9.1\% were also included Big Band, Broadway Shows, Comedy, Contemporary, Electronic, EMO, Ethnic, Exercise, Folk, Gothic, Grunge, Holiday Music, House Music, Humor, Instrumental, Language, Latin, Love Songs, Mix, Mellow, Modern, Ska, Spoken workd, Standards, Swing, Top-40, and Trip-hop. RIAA, 2008 Year-End Shipment Statistics, http://76.74.24.142/D5664E44-B9F7-69E0-5ABD-B605F2EB6EF2.pdf (last visited Apr. 22, 2010).

${ }^{136}$ See, e.g., Richard Dyer, Amplification: Turn It Up, or Turn It Down? Opera Companies Split on the Issue, Boston GlOBE, Apr. 17, 2005, www.boston.com/ae/music/articles/2005/04/17/amplification_turn_it_up_or_turn_it_down?mode=PF. Anthony Tommasini, Opera Is at a Technological Crossroads, N.Y. TIMES, Jan. 10, 2006, www.nytimes.com/2005/12/30/arts/30iht-loud.html?pagewanted=print. 
their 30s and 40s, than those who frequent late night music clubs. ${ }^{137}$

People generally enjoy performances more as members of an audience. We constantly talk with each other about music and movies because finding others that share our enthusiasms is pleasurable in itself, even if we never attend a performance together. Expressive culture, which seems to help create and sustain social bonds, now is delivered by technologies that isolate us from each other and allow us to neglect even to establish and experience social bonds. ${ }^{138}$

Recent research findings strongly suggest an unexpected and rapid decline in the number of our strong "core discussion networks, with a shift away from ties formed in neighborhood and community contexts and toward conversations with close kin (especially spouses).”139 Contemporary technology moulds our experience of copyright properties into an increasingly private and individual experience. We may sit by the fireplace to read a book, but we no longer gather around a campfire to hear storytellers or poets. We no longer even gather with friends in baroque movie palaces to see the latest Hollywood offerings, scheduled for certain evenings and specific times. Instead, in the privacy of our homes we watch videos at odd hours of the day, whenever the impulse strikes.

Affluence itself has constrained the social experience of expressive culture. Our houses have grown dramatically larger as our families have grown smaller. ${ }^{140}$ In the distant past, even if the technology had existed, the private spaces for solitary experiences were nonexistent or at

\footnotetext{
${ }^{137}$ Neil Strauss, Acoustic Music, Live From the Living Room, N.Y. TIMES, Nov. 8, 1999, at A1.

${ }^{138}$ Robert Putnam, writing extensively about our loss of social connections, emphatically states that “[n]othing-not low education, not full-time work, not long commutes in urban agglomerations, not poverty or financial distress-is more broadly associated with civic disengagement and social disconnection than is dependence on television for entertainment." PUTNAM, supra note 124, at 231 (citation omitted). The importance of this increasing recognition of social isolation and its consequent dangers is that "civic connections help make us healthy, wealthy, and wise." Id. at 287. See also infra notes 154-155 and accompanying text.

${ }^{139}$ Miller McPherson, Lynn Smith-Lovin \& Matthew E. Brashears, Social Isolation in America: Changes in Core Discussion Networks over Two Decades, 71 AM. SoC. REV. 353, 353 (2006). 140
} 
least rare. ${ }^{141}$ In hunting and gathering bands, solitude required separation from the group, which also dramatically increased the risks of predation from animals or human competitors. ${ }^{142}$ While prehistoric individuals could easily escape their groups and wander the wilderness alone, such circumstances dictated heightened vigilance, not the inattentive creative reverie of aesthetic immersion. In more settled times, the large families typical of pre-modern eras usually lived in small living spaces, often one room, which limited opportunities for solitude. In medieval Europe, solitude was virtually unknown. ${ }^{143}$

Increased affluence provides the gadgetry that delivers the entire world's expressive culture to our homes, but this same affluence reduces the opportunity for social experience of that culture. Prior to the contemporary era of extreme miniaturization and inexpensive electronic technologies, most of us inhabited what would now be called an impoverished media environment. The current era offers much more privacy in living arrangements and many more solitary entertainments - individual cell phones capable of playing music, computer games and short videos, music reproduction systems of various kinds, and DVDs and other technologiesall to tempt the solitary person away from group interaction and provide an ersatz community through computers and the ubiquitous Internet. Public social spaces, the public taverns and cafes, have disappeared because part of their historic appeal came from the paucity of alternatives.

\footnotetext{
${ }^{141}$ See infra note 143 and accompanying text.

142 See, e.g., HART \& SUSSMAN, supra note 52, at 170 (“[G]roup living equals safety in numbers. . . . More eyes, ears, and noses meant less risk of unseen, unheard, unsmelled predators sneaking up to eat you.” (citation omitted)). 143 "People crowded together cheek by jowl, living in promiscuity, sometimes in the midst of a mob. In feudal residences there was no room for individual solitude, except perhaps in the moment of death. When people ventured outside the domestic enclosure, they did so in groups. No journey could be made by fewer than two people ....” Georges Duby, Solitude: Eleventh to Thirteenth Century, in A History OF PRIVATE LifE: II: REvELATIONS OF THE MEdieval World 509, 509 (Georges Duby ed., Arthur Goldhammer trans., 1988). “Men and women who traveled the roads without escort were believed to offer themselves up as prey, so it was legitimate to take everything they had." Id. at 510 .
} 
Technology has had an enormous impact on our individual subjective experience of expressive works, by changing the social and even physical environments in which these experiences take place. For millennia both the creation and experience of expressive works occurred in communal gatherings, ${ }^{144}$ in social contexts in which the audience gathered to experience and often participate in the work for a particular shared purpose. Until the invention of playback technologies, we could not experience expressive works in solitude. Playback technologies allow us to experience works in contexts and places unrelated to their creation and with none of the visual or other cues that once comprised a significant part of the experience. What must be the typical person's experience ratio of live performance to recorded media? Few besides professional critics or performers experience cultural works predominantly live. Solitary listening to music is now not just the predominant form of musical experience, ${ }^{145}$ but for many the exclusive one. ${ }^{146}$

Most of those few live performances that we do still experience are themselves radically different from what earlier societies experienced. We congregate at concert halls and theaters as anonymous individuals among crowds of strangers. Contrast this with the quite different way we must have experienced expressive works in pre-modern times—in specific ceremonial spaces that added meaning to the performance, surrounded by friends, neighbors, and kin sharing a common purpose in a society with few strangers and deeply rooted in particular locales. The strength and endurance of the African American church may owe much to the large role that musical performance plays in its worship services shared by its congregations whose members

\footnotetext{
${ }^{144}$ See Dissanayake, supra note 103, at 31.

145 See KATZ, supra note 6, at 17.

${ }^{146}$ In the course of a year only $36 \%$ of literary readers and $10 \%$ of non-readers attended a performance of a play or musical. And even fewer of both literary and non-readers attended jazz or classical concerts-29\% of literary readers and 9\% of non-readers. ARTS REPORT NO. 47, supra note 127, at 18.
} 
are often deeply involved in each others' lives.

While much of this discussion has concerned our experience of music, analogous developments have occurred in all the mediums in which culturally expressive works are created and which are the central concern of copyright. ${ }^{147}$ Whether such fundamental changes in our experience should concern us depends upon whether such changes are really "fundamental." If they are not, then we have technology to thank for the convenience and ubiquity of technologies that permit us to play many varieties of works whenever and wherever we choose. But if they are, then how should copyright policy reflect this concern?

\section{COPYRIGHT FOR A SOCIAL SPECIES - POLICY GOALS}

What would our Copyright Act look like if we used copyright to encourage and facilitate the sociality of our species? On the evidence of how Congress responds to lobbying and campaign contributions, the current Act's de facto goal is to maximize copyright industry revenues. Conceivably this goal serves as a proxy for the well being of authors and artists, but having observed the legislative process, such an explanation is unlikely. Accommodating copyright policy goals to our species' social nature requires both a change of focus and a loosening of copyright's strictures. Increasing copyright industry revenues should no longer equate with success, and strengthening copyright becomes a hindrance rather than a stepping stone to our goals.

Many authors do poorly under the present system, dependent as it is on the interests and influence of the copyright industries and manufacturers of entertainment hardware (the only other group concerned with copyright policy and with both the expertise and resources to lobby

\footnotetext{
${ }^{147}$ See discussion infra pp. 58-59.
} 
Congress and contribute significantly to political campaigns). However, if we conceive the ultimate goal of copyright policy as satisfying and facilitating the impetus that drives us to create and experience expressive culture, then the instrumental goals must encompass more than the financial rewards ${ }^{148}$ authors accrue and include the creative activities of authors and the social environments in which creation and consumption occur. Taking music as an example, reforming copyright policy by curtailing some of the copyright monopoly does not create a zero sum game in which reducing music composer royalties merely increases the profits of performers who have been freed from the transaction costs and expenses of obtaining performance licenses.

Performers have also been freed to perform and create in ways and places that current copyright doctrines prohibit (or at least inhibit). Of even greater consequence, the increased innovation generated by environments more compatible with social creation will benefit consumers and author/performers.

Once the social dimension of copyright enters the calculus, then merely creating a "flourishing entertainment culture"149 that does not extend beyond rewarding artists and performers with the incomes needed to support their families in comfort would still accomplish too little. Such an impoverished conception of copyright's goals ignores the social context and environment in which creation and consumption occur. Reducing the scope of copyright protection might well diminish copyright license revenues. But it might also stimulate greater production, ${ }^{150}$ enhancing live performance incomes in excess of license royalty declines. ${ }^{151}$ Even

\footnotetext{
${ }^{148}$ These include not just copyright license royalties but also performance and other fees generated by their labor. ${ }^{149}$ William W. Fisher III, Promises to KeEP: Technology, LaW, AND the Future OF ENTERTAinment 215 (2004) (identifying the public interest with sustaining a "flourishing entertainment culture").

${ }^{150}$ Sometimes cutting excessive income taxes can stimulate so much additional economic activity that total revenues increase. This is not inevitably so, notwithstanding the political hyperbole that supports such a policy prescription. ${ }^{151}$ See Raymond Shih Ray Ku, Promoting Diverse Cultural Expression: Lessons from the U.S. Copyright Wars, 2 ASIAN J. WTO \& INT'L HEALTH L. \& POL'Y 369, 384-89 (2007), which cites data showing that since widespread use of the Internet, CD unit sales have declined but concert revenues have soared and performers receive a greater share
} 
more importantly, increasing live performances might create a more satisfying cultural environment for us all.

If we broaden our conceptions of the factors that spur copyrighted creations beyond the economic, then it naturally follows that copyright policy should facilitate these non-economic drives $^{152}$ that foster the benefits that have led all human societies to invest such a disproportionately large share of their resources in activities that have no obvious survival value. If a consequence of augmenting the creation and experience of expressive culture is the strengthening of social bonds, ${ }^{153}$ then it may capture benefits, social and economic, which have important public health implications.

Social connectedness dramatically reduces mortality and has numerous other important public health benefits. ${ }^{154}$ "[T] $]$ he positive contributions to health made by social integration and social support rival in strength the detrimental contributions of well-established biomedical risk factors like cigarette smoking, obesity, elevated blood pressure, and physical inactivity." ${ }^{155}$ So the calculus of the burdens and benefits of the copyright monopoly, even when limited to economic phenomena, must extend well beyond the aggregate revenues of the copyright industries. Limiting the analysis so narrowly fails to consider the benefits (and perhaps unrecognized burdens) whose significance might dwarf those interests that so assiduously lobby

of concert revenues than they do of CD sales revenues.

152 Some copyright commentators have emphasized individualistic spiritual or inspirational (noneconomic) motivations for innovation. Relying on such motivations increases the importance of moral rights and highlights the individual author as an autonomous individual divorced from a social milieu. See Roberta Rosenthal Kwall, Inspiration and Innovation: The Intrinsic Dimension of the Artistic Soul, 81 NotRE DAME L. REV. 1945 (2006).

153 See Dissanayake, supra note 103, at 24-29. "We moderns feel 'art' to be a private compulsion, a personal desire to mold or make something out of one’s individual experience. But art actually originated and thrived for most of human history as a communal activity: in the smaller and more interdependent and like-minded societies in which humans evolved, the need to make sense of experience was satisfied in communally valued and validated activities." Id. at 31 .

154 See PUTNAM, supra note 124, at 326-35.

${ }^{155} \mathrm{Id}$. at 326-27. 
the Congress on copyright policy.

\section{A. Copyright Inhibitions}

Current copyright law inhibits the social consumption and creation of expressive culture. If expressive culture provides adaptive advantages through strengthening social bonds or other yet to be discovered benefits, copyright law, which regulates how and when we experience cultural works, inhibits this valuable function. This results not through deliberate policy choice but as one of its unintended consequences. Moreover, this is not a longstanding and deeply embedded cultural phenomenon but a relatively recent consequence of legal rules scarcely a century old.

Public performances and public displays are exclusive rights that copyright allocates to owners. ${ }^{156}$ Public performances or displays occur then the audience for live or recorded performances or displays consists of more than a family and its social acquaintances or when performances or displays are transmitted to anonymous members of the public even when these members listen or watch in the solitude of their homes. ${ }^{157}$ In contrast, private display and private performance require no permissions, violate no prohibitions, and are available to anyone with lawful possession of a copy of the copyrighted work. In this way copyright has a structural bias favoring solitary or private consumption. ${ }^{158}$

\footnotetext{
${ }^{156}$ See 17 U.S.C. § 106(4), (5) (2006).

${ }^{157}$ The public performance and display rights allow copyright owners to control the public performance of literary, musical, dramatic, and choreographic works, pantomimes, motion pictures, and other audio visual works, and the public display of literary, musical, dramatic and choreographic works, pantomimes, and pictorial, graphic or sculptural works. Works are performed or displayed publicly where either occurs at a place open to the public or where a substantial number of persons outside of a normal circle of family and its social acquaintances is gathered. Public performance or display includes the transmission or communication of the works to a public place or to the public, whether members of the public receive the performance or display in the same or separate places and at the same or different times. Id. § 101.

${ }^{158}$ I use the term "solitary" to designate consumption by a single individual. "Private" is used to mean nonpublic,
} 
Of all the rights that comprise the intellectual property called copyright, it is the public performance and public display rights that most directly govern our experience of cultural works. To perceive works with our senses, they must be performed or displayed. Even narratives, which we have come to think of as a solitary experience, performed only in the abstract space of our mind, were originally performed out loud. ${ }^{159}$ Well into the nineteenth century, many writers earned more income performing their works at public readings than from sales of copies. ${ }^{160}$ Nevertheless, in the evolution of copyright the full scope of the public performance right developed relatively recently.

During copyright's formative period, consumption through public performance or public display was outside the scope of copyright. ${ }^{161}$ Public performance rights became one of the exclusive rights granted by copyright in 1856 with the grant of public performance rights to dramatic compositions (plays). ${ }^{162}$ Not until 1897 did the scope of copyright extend to the public performance of musical works. ${ }^{163}$ Even under the 1909 Act, an unauthorized public performance of a musical or non-dramatic literary work would infringe only if it were “for profit.” 164 Initially, it was not clear if the “for profit” element required a separate admission charge or whether courts would consider the economic arrangement as a whole, but by 1917, after twenty years experience with the new expansion of the public performance right, the Supreme Court had

with "public" having the meaning given in the Copyright Act. See infra note 236 and accompanying text.

${ }^{159}$ For the origins of the practice of silent reading, see discussion supra pp. 27-28. Previously, works were read out loud even by solitary individuals.

${ }^{160}$ See Peter G. Buckley, Popular Entertainment Before the Civil War, in 3 ENCYClOPEDIA OF AMERICAN SOCIAL HisTORY, supra note 107, at 1611, 1622.

${ }^{161}$ Ironically, in England, the birthplace of copyright, composers resisted the extension of copyright to cover music, so even unauthorized reproduction was unregulated by copyright. See Michael W. Carroll, The Struggle for Music Copyright, 57 FLA. L. REV. 907, 925-30 (2005).

162 Act of Aug. 18, 1856, ch. 169, 11 Stat. 138, 138-39 (current version at 17 U.S.C. § 106(4) (2006)).

163 Act of Jan. 6, 1897, ch. 4, § 4966, 29 Stat. 481, 481-82 (current version at 17 U.S.C. § 106(4) (2006)).

${ }^{164}$ Act of Mar. 4, 1909, ch. 320, § 1(c), (e), 35 Stat. 1075, 1075-76 (repealed 1976). There was no "for profit” requirement to infringe a dramatic work. See 2 Melville B. NimMER \& DAVID Nimmer, NimMER ON COPYRIGHT $\S$ 8.15[A] (2003) [hereinafter NimMER On COPYRIGHT] (“The Discarded 'For Profit' Distinction”). See id. for the rationale for the different treatment of dramatic works. 
chosen the latter alternative. ${ }^{165}$ For barely more than one hundred years has copyright even concerned itself with the social consumption of music, and for less than eighty years has copyright prohibited the kind of social experience of music advocated here. Since the creation of the public performance and display rights, technology has drastically changed the original policy and economic balance struck between the competing interests of performers and authors. An analysis of how technology has distorted the initial balance suggests how we might realign these competing interests and still avoid inhibiting the social experience of expressive works.

1. The 1909 Act Balance and the Role of Publication. - The previous 1909 copyright statute, enacted at the dawn of the era of the recording technologies that threaten our sociality, was more attuned (inadvertently) to the social aspects of our species. The central role played by publication in creating the exclusive rights granted by copyright accommodated the evolving dynamic nature of socially created works. Under the 1909 Copyright Act (as well as the current one), performance did not publish a work. ${ }^{166}$ The 1909 Act required publication with notice to create and to vest federal copyright and to divest the perpetual state common law copyright. ${ }^{167}$ Thus, performance of a musical score at a night club or concert hall, or the live theatrical performance of a play on Broadway, neither published the musical work nor the play (publication without notice placed the work in the public domain) nor gave rise to federal copyright protection. The only alternative to achieve protection for an unpublished work was to deposit a copy of the work. ${ }^{168}$

In some media, this presented no great burden, e.g., music for phonograph

\footnotetext{
${ }^{165}$ Herbert v. Shanley Co., 242 U.S. 591, 593-95 (1917), held that an orchestra performance in a restaurant was "for profit" even though there was no separate admission charge to hear the music.

${ }^{166}$ See Act of Mar. 4, 1909, ch. 320, § 12, 35 Stat. 1075, 1078 (repealed 1976); see 17 U.S.C. § 101 (2006) (“A public performance or display of a work does not of itself constitute publication.”). See also 1 NimMER ON COPYRIGHT, supra note 164, § 4.08[A]-[B] (2004).

${ }_{167}$ Act of Mar. 4, 1909, ch. 320, § 9, 35 Stat. 1075, 1077 (repealed 1976).

${ }^{168}$ See id. § 12, at 1078.
} 
records. However, with respect to that most insatiable purveyor of dramatic performances, television (and to a lesser extent, radio), the volume of such performances and exigencies of time in connection with the preparation of material therefore rendered the burden of prior deposit almost insurmountable. At the other end of the dramatic spectrum - the legitimate stage production - there are generally no problems of volume or of limited time for preparation. Yet, here too a prior deposit requirement would have proven most burdensome. The practice of making numerous revisions in a play during the period of public performance is well-known. To require a deposit in the Copyright Office before permitting a revision to be performed in the pre-Broadway runs or even thereafter would obviously seriously hamper the development of a play. ${ }^{169}$

If performance were a publication, then a single failing to make a timely deposit of each version of a rapidly changing work in development would forfeit the work to the public domain. ${ }^{170}$ This arrangement allowed the work to remain unfinished and permitted the collaborative give and take of performers and authors to both revise the work and react to the responses of preview audiences. These works were not just socially experienced; they were also socially created, much as plays were in Shakespeare’s day. ${ }^{171}$ Within the structure of the 1909 Act the "performance is not a publication" rule avoided the otherwise competing choices of either forfeiting copyright protection or freezing development of new works prematurely. In this manner the 1909 Act supported social creation.

Another provision of the 1909 Act facilitated social consumption. The heavily criticized juke box provision ${ }^{172}$ explicitly exempted the performance of music on a coin-operated machine in bars and restaurants from the public performance right, unless a fee was charged for admission

\footnotetext{
1691 NIMMER ON COPYRIGHT, supra note 164, § 4.08[B] (2004) (citations omitted).

${ }^{170}$ Technically, only the variations from the version previously deposited would enter the public domain.

${ }^{171}$ One problem that scholars have in identifying the definitive texts of Shakespeare's plays is that in his era they were constantly revised in response to audience reactions, and there may have been no single definitive text in that era.

${ }^{172}$ See 2 NimMER ON COPYRIGHT, supra note 164, § 8.17[A] (2005) (“After more than 50 years of unsuccessful efforts to repeal this indefensible windfall enjoyed by a half-billion dollar per year industry, the jukebox exemption finally met its demise in the current Copyright Act.” (citation omitted)).
} 
to the place of performance. ${ }^{173}$ The 1976 Act replaced the exemption with a compulsory license, and the subsequent Berne Convention Implementation Act substituted a negotiated license. ${ }^{174}$ The exemption ${ }^{175}$ encouraged listeners to combine two social activities, listening to recorded music while eating or drinking — quintessential social activities. While the provision's original purpose was an entirely different one- - to increase the sales of sheet music for amateur performance—its encouragement and support for social consumption of expressive works is consistent with the reorientation of copyright policy that I urge here. ${ }^{176}$

Notably, the juke box provided the only public environment, both egalitarian and participatory, that allowed individual members of the public to select particular works for public performance in a social setting. No other such environment existed or exists in American society. Through their musical choices, patrons in public spaces with juke boxes could establish a common identity for their restaurant, tavern, or social gathering place. ${ }^{177}$ Compatible choices fostered social cohesion sufficient to create a sense of belonging. Owners and operators of the facility played a key role by choosing to stock their juke boxes with particular musical genres intended to appeal to their desired clientele, but patrons through their selections over time and in

\footnotetext{
${ }^{173}$ Act of Mar. 4, 1909, ch. 320, § 1(e), 35 Stat. 1075, 1076 (repealed 1976). See Warner Bros., Inc. v. O’Keefe, 468 F. Supp. 16, 20 (S.D. Iowa 1977) (holding exemption not applicable where admission charged at the door); Irving Berlin, Inc. v. Anziano, 4 F.R.D. 33, 34 (S.D.N.Y. 1944).

174 17 U.S.C. § 116(b) (2006).

${ }^{175}$ The juke box industry was in decline even before the elimination of its complete exemption by the 1976 Act, although its revenues still approximated \$500 million annually. See S. REP. No. 94-473, at 95 (1975).

176 "The exemption for coin operated machines was intended to shield the promotional playing of songs in penny arcades, which were thought to increase the sales of sheet music.” Jessica Litman, Copyright Legislation and Technological Change, 68 OR. L. REV. 275, 287-88 n.62 (1989) (citing H.R. REP. No. 60-2222, at 7-9 (1909)). 177 Jukeboxes were generally of two types. In the first there was a large coin operated juke box containing a selection of records in a single location. Patrons had to go to it to make selections and might expect comments on their choices as other patrons waited their turn to make their own choices. Selections typically played in the order of selection. If nothing was currently playing, their choices could not be anonymous even when unobserved. Often a crowd would surround the juke box and a patron would be directly observed making choices. In the second type of juke box, each booth in a restaurant or tavern would have a satellite machine into which coins could be deposited and choices made from a large rolodex-like apparatus. The actual records and phonograph were located elsewhere, but the satellite had its own speakers, and all choices made from any booth could be heard in all other booths. This was the less "social” arrangement.
} 
sequence independently contributed to the formation of their bar or restaurant's identity.

Through this process the archetypal 1950s neighborhood soda fountain became the popular teen hang out, featuring the rock and roll that their parents abhorred. Such a venue was even mildly interactive. Since a patron could not tell when in the common queue her selection would play, selections were influenced by previous and currently playing selections as well as by the anticipated selections of those depositing coins in the apparatus. Patrons with competing tastes might engage in subtle contests to establish dominance or to establish communal playlists. From this article's perspective, the elimination of an exemption that merely subsidized the social consumption of music in an interactive setting, solely to conform to copyright treaty obligations, was a significant loss.

\section{B. The Original Balance Between Authors and Performers}

When the Congress enacted the 1909 Act, the music recording and motion picture industries were in their infancy. Most expressive works were still experienced in live performance. Performers, who were often creators as well, did not, unlike today, compete against the entire recorded output of the cumulative past. Composers and playwrights necessarily competed against the reputations of the established giants in their fields, but performances of the works of these giants still required the engagement of live performers and so were far less frequently heard. Actual performances by the giants themselves were rare and fortunate occurrences in the lives of virtually everyone and became treasured and mythic memories, recollected (and embroidered) with the passing decades. Today’s technology provides the best of the recorded past anytime, anywhere, to virtually anyone, and at ever decreasing costs. This technology has made much of the current Copyright Act obsolete, but 
perhaps we should revisit some features of the even older 1909 Act in the service of a different purpose - the social creation and experience of our culture.

At the inception of the public performance right for musical compositions (1897), the only valuable and tangible form for such works was as sheet music. ${ }^{178}$ (No enforcement mechanism yet existed to collect public performance royalties.) Only a few gifted individuals, typically accomplished musicians, can enjoy music in the form of a music score. For the rest of us, to enjoy music necessitates someone to perform it. Public performance necessitated a live performing musician, and fees for such performances provided the livelihood of professional musicians. A few performers also composed the works they played, but most popular works were composed by professional songwriters, denizens of the legendary “Tin Pan Alley.”179 For a work to become a popular "hit” many musicians, professional as well as amateur, would have had to purchase the sheet music. In the early twentieth century "music publishers licensed the right to perform music as part and parcel of the sale of [sheet music] copies." ${ }^{\text {180 }}$ The monopoly given to the composer over sales of his sheet music created the necessary incentive for new compositions, which increased the costs of public performance by the license amount. ${ }^{181}$ While copyright protection might appear to merely shift revenues (license fees) from performers to

\footnotetext{
${ }^{178}$ Until the establishment of performing rights organizations, monetizing the public performance right was impractical and prior to the invention of the recording industry, the only reproduction of music was in the form of sheet music.

${ }^{179}$ Russell Sanjek writes:

The sheet-music business prospered, ... growing from the small group of music houses in the late 1890s that constituted Tin Pan Alley, on West 28th Street in Manhattan, to fortyfive companies, capitalized at $\$ 1.6$ million and with a value of $\$ 2.2$ million in $1904 . .$. After years of political maneuvering and lackadaisical lobbying by the music business, these new users of Tin Pan Alley's products became responsible for paying a royalty when they selected music copyrighted after July 1, 1909. SANJEK, supra note 132, at 16.

${ }^{180}$ Litman, supra note 176, at 338 n.346.

${ }^{181}$ In 1914 a group of popular composers formed the American Society of Composers, Authors and Publishers (ASCAP), the first performing rights organization, to monitor and enforce the new public performance right in musical compositions. See GORMAN \& GINSBURG, supra note 14, at 673-74.
} 
composers, hit scores would dramatically increase the demand for music performers to play them and expanded their performance fees far in excess of performance royalties owed to composers. $^{182}$ Frequent and well-played compositions would also increase the sales of music scores required for additional performances by other performers, especially amateurs, until consumer demand was satisfied. Since a vibrant live performance culture required both roles, so long as license royalties were reasonable, this arrangement benefited both composers and performers in the era before electronic recording and reproduction. Neither could prosper without the other.

The advent of the contemporary era's nearly perfect sound recordings significantly changed the calculus. When recordings replace live performers, live performers receive compensation only once, when the recording is made. ${ }^{183}$ (I exclude from consideration the very recent public performance right in sound recordings for digital audio transmissions (DAT), because the amounts so far are quite small.) ${ }^{184}$ Thereafter only the composer receives payment

\footnotetext{
${ }^{182}$ Song "plugging” brought songs to the public's attention. It was essentially an early form of payola and consisted of payments to popular vaudeville and other performers who would perform songs with the expectation that it would spur sales of sheet music during the initial decades of the twentieth century. See SANJEK, supra note 132, at 80-105.

${ }^{183}$ Even if the composer is a member of the performing group and retains ownership of copyright in the composition (the musical work), a frequent occurrence in jazz, sidemen will receive payment only for their services at the particular recording session. In the 1959 recording of Miles Davis' Kind of Blue, one of the most famous and critically acclaimed jazz albums of all time, John Coltrane, at that time recognized as one of the two leading performers on tenor saxophone (the other being Sonny Rollins), received only $\$ 64.67$ for his services during three and a half hours of studio playing time in the first of two recording sessions that produced the album. See AsHLEY Kahn, Kind of Blue: The MaKing of the Miles Davis Masterpiece 94-95 (2000). Davis interceded with the record label to secure "an additional $\$ 100$ for the more senior members of his group ...." Id. at 95 . By the year 2000, it was projected that this album, which averaged five to seven thousand copies sold every week in the 1990s, would sell over five million copies worldwide, including the more than one million in documented international sales since 1997—all with little promotional effort. Id. at 193-94, 198. Given the predominant role of improvisation in modern jazz, which frequently uses the chord changes of a popular melody as merely the starting point, it seems the odd author's incentive to reward composers with compensation for the public performance of the "composition," e.g. radio broadcast, of the recognizable melody of the musical work but not the performers who have improvised (and composed) virtually their entire recording and still receive nothing.

${ }^{184}$ The Digital Performance Right in Sound Recordings Act of 1995, Pub. L. No. 104-39, 109 Stat. 336, provides some compensation for performers on music recordings, but its anticipated widespread impact will not occur until digital broadcast media supplant the current analogue broadcast media. Its initial impact is in the emerging new industries of satellite radio and webcasting. Simplifying somewhat, under current law 50\% of royalties are
} 
when recordings are performed. A few performers earn enormous sums from the sales of many millions of their recordings, but it takes many gold and platinum albums in succession to reach this level. Only a very small number of musicians ever do. ${ }^{185}$ Popular composers who also enjoy bargaining leverage under this system might earn enormous sums, but performers have only one chance at a payday, and they generally lack negotiating leverage and must bargain in the familiar copyright context in which the ex ante valuation of their contributions is both difficult and speculative.

As a result, most royalties produced by the music public performance right are generated from the public performance of recordings, whether on the Internet or radio, or as background music for movies or television, or in restaurants or other public accommodations. In such circumstances no live performer is paid and even the recording artist, unless also the composer, receives no compensation (unless the public performance is through the medium of a digital audio transmission, the narrowly circumscribed public performance right in sound recordings). ${ }^{186}$ In such an economic environment the original trade off made in the 1897 and 1909 Acts between composers and performers when the music public performance right was first created, has lost its balance and should be renegotiated. At that time every public performance within copyright's grant required the hiring of flesh and blood performers to play the composer's music. Rarely does this occur today.

Renegotiating the balance will be more than difficult. Public choice theory suggests that

\footnotetext{
distributed to the copyright owner of the digital transmission right in the sound recording, $45 \%$ to recording artists "featured" on the sound recording, and of the remaining $5 \%, 2 \frac{1}{2} \%$ is allocated to "nonfeatured musicians" and $2 \frac{1}{2} \%$ to "nonfeatured vocalists." This final 5\% to nonfeatured performers is not paid to musicians associated with a particular recording but to a general category of performer in the industry. See 17 U.S.C § 114(g)(2)(A)-(D) (2006). Digital audio transmission gives performers a revenue stream, but it also forces them to compete in a winner-take-all market.

${ }^{185}$ See infra notes 206-209 and accompanying text.

18617 U.S.C. § 114 (2006). This arrangement may change in the near future if Congress enacts the Performance Rights Act, S. 379, H.R. 848, 111th Cong. (2009).
} 
when one side consists of a few very large, global firms with many repeated interactions, these entities can relatively easily find common cause and negotiate a course of action. ${ }^{187}$ When the opposing side consists of a large number of very small and geographically scattered entities, largely unknown to each other and lacking professional management or lobbyists, the first side (large, global firms) will invariably prevail. The dispersed opponents will have difficulty identifying themselves and working out common positions or strategies. ${ }^{188}$ The performance of live music is a labor intensive cottage industry, and music recording is the polar opposite. Musicians are typically self-employed or employed by orchestras or band leaders. Only symphony musicians are employed by organizations that can claim institutional permanence or continuity, and even these institutions hardly compare to international record distributors. They would be subsumed within the rounding errors included in the financial statements of the global firms that dominate recorded music. In such a business environment, the evanescent and ephemeral qualities that live performance might add to the experience of music are easily overlooked. They are neither objectively obvious nor easily articulated. ${ }^{189}$ With the billions of dollars supporting the marketing and promotion of recordings, there exists no entity sufficiently large or rich enough to offer an effective counterweight in favor of live performance. No wonder live performance is devalued.

The most recent technological advances, digitalization and the Internet, compound the difficulty of renegotiating a new balance because they imperil the existing revenue streams of so many firms and threaten the established business models. Now that we approach the threshold of

\footnotetext{
${ }^{187}$ DANiel A. FARBer \& Philip P. Frickey, LAW ANd Public Choice: A Critical InTROduction 19, 23 (1991).

${ }^{188}$ The Future of Music Coalition, a grass roots lobbying organization composed of working musicians, is attempting to redress this imbalance of resources in Washington. Future of Music Coalition, http://www.futureofmusic.org/ (last visited Apr. 22, 2010).

${ }^{189}$ They might even not exist, but this article is premised on their existence.
} 
realizing "the jukebox in cyberspace” with every musical or audio visual work ever created available at anytime to anybody (with a wireless broadband connection and the necessary hardware), the distinction between public and private performance has eroded.

When we listen to a work in our home, it is a private performance if the listener owns the work embodied in an object of tangible personal property, even if the listener acquired the work through a digital download, and generates the performance with her own hardware; copyright does not extend to private performances. ${ }^{190}$ The listener owes no royalty and needs permission from no one, but the owner of the reproduction right received payment for the copy the listener owns. If instead the listener subscribes to a cyberspace service that transmits the performance from outside the home into the listener's home, then it is a public performance and within the scope of copyrights' exclusive grant. The transmitter needs permission and owes royalties to the owners of the public performance rights. ${ }^{191}$ Since no one knows how consumers will choose among competing variations of these technologies and services, valuing with any certainty the rights underlying the revenue streams they might generate (in this instance the reproduction and public performance rights) becomes impossible. ${ }^{192}$ Striking a deal when technological and consumer choices are still so fluid risks giving away unrecognized jewels.

Rapid advances in storage media also confound valuations of the exclusive rights. Many baby boomers have already replaced vinyl LPs with cassettes and then cassettes with CDs, ${ }^{193}$ before moving on to ripping songs from CDs or downloading digital copies and storing them on

\footnotetext{
${ }^{190}$ See 17 U.S.C. § 106(4) (2006).

${ }^{191}$ This scenario involves two public performance rights, for the musical work and for the sound recording. See id. $\S \S 106(4), 114$.

${ }^{192}$ One of the unresolved issues includes whether buffer and server copies required to stream audio over the Internet are within the compulsory mechanical license or require individually negotiated licenses. But see The Cartoon Network v. CSC Holdings, Inc., 536 F.3d 121 (2d Cir. 2008) (holding that a buffer copy was not a copy for infringement purposes and thus required no license at all).

${ }^{193}$ This does not include formats that never achieved dominance, i.e., eight track tapes, quadraphonic records, digital audio tape, or super audio CDs.
} 
computer hard drives or in MP3 players. We have started a similar cycle with audiovisual works. We began with Betamax and VHS tapes, replaced these with DVDs, and now await the imminent arrival of high definition (Blue Ray) DVDs, which require yet another outlay for works we already own. Each successive format has as increasingly shorter life span, but until the realization of the juke box in cyberspace fans had no choice but to modernize their formats because their playback hardware had become obsolete and could no longer be repaired or replaced.

Now consumers have a choice, buy new copies in each new format as they develop as they have always done and reward the reproduction right, or subscribe to a cyberspace service, rewarding the public performance rights, and let the service worry about keeping current with advances in storage media and coping with the rapid obsolescence of hardware, so long as the “celestial jukebox” provides at least as much convenience as owning the work. How consumers value cost equivalence, convenience, portability, and perhaps other factors will determine the likely winners, but existing business models are almost certainly doomed.

If an “on demand” digital performance delivered via satellite or the Internet is deemed a public performance, even though it effectively substitutes for a CD, then revenues produced by sales of copies of recorded media and allocated by recording and distribution agreements among performing artists, record labels, and record distributors, and by mechanical license provisions to songwriters, have been shifted to a more limited group. Under customary industry provisions, now only performing artists and composers would receive revenues both generated and allocated by statutory licenses and blanket negotiated licenses. Such a redirection of the revenues (of unknown magnitude) generated from consumer demand for recorded music does little to restore the balance between performers and composers struck by the original public performance right in 
1897. But it does create enough uncertainty, despite the compromise contemplated in $\S 116$ that the content industries have yet to reach the consensus needed to permit full exploitation.

A parallel situation exists with the copyright status of live and recorded performances of dramatic and comedic works. There too technology threatens established business models and predictable revenue streams. When created in 1856, the public performance right for dramas and comedies was premised on live public performances. Although far more people can enjoy reading the script of a play than can enjoy reading a music score, outside of the classroom comedies and dramas are not read but watched. At present, it is overwhelmingly recordings of dramatic and comedic performances, in one format or another-movies , television, the Internet, or DVDs - that people watch. Live theater, with the exception of Broadway, is a hodgepodge of small, regional, and community theaters supported by government and foundation grants and other noncommercial support. ${ }^{194}$ Although comedy clubs, as venues for live performances have proliferated over the past several decades, are thoroughly part of the for-profit sector, they are small and inconsequential even compared to live theater and exist largely outside copyright protection. ${ }^{195}$ The counterweight to live performance, recorded dramas and comedies, are manufactured in Hollywood, in spirit if not always in fact, by large motion picture and television production studios with their own distribution channels. ${ }^{196}$ Even low budget independent productions require millions of dollars, and big budget features can cost more than $\$ 100,000,000$

\footnotetext{
${ }^{194}$ In 1992, the last year for which data are available, tax exempt live theatrical producers outnumbered taxable live theatrical producers, 1,217 to 915, but these same tax exempt producers generated less than $60 \%$ of the revenues of taxable producers, $\$ 749$ million versus $\$ 1.3$ billion. Broadway productions and road shows accounted for only 79 of these taxable live theatrical producers and generated \$598 million in revenues, or about 30\% of all theatrical revenues. Tax exempt producers received $8 \%$ of their revenues from government support and $24 \%$ from private donations or about one third of total revenues. See NAT'L EnDOWMENT FOR THE ARTS, NOTE No. 66, THEATERS REPORT 22\% GROWTH IN ECONOMIC CENSUS: 1987-1992 (1998). 195

196
} 
to make and nearly as much again to market. ${ }^{197}$ Television, while cheaper, is still expensive. A network series can easily cost $\$ 1,000,000$ per weekly episode. ${ }^{198}$ Media conglomerates, only a few in number, finance, produce, or market most recorded dramas and comedies. ${ }^{199}$ In contrast, the many thousands of actors and comedians who perform live on stage survive as marginal independent contractors. A very few achieve stardom and negotiating leverage with the media conglomerates that control recordings of their performances. But even few Hollywood stars achieve the kind of enduring fame that creates financial leverage over decades. Most have only brief careers in the spotlight and many thousands labor in anonymity. Live performers have no chance in any legislative influence contest against the major media firms.

\section{Competing with the Cumulative Past}

When live musicians and performers in dramas and comedies compete with electronic recordings they compete not only with the best performers of the current or any previous era, but they also compete with the best performances of those best performers. ${ }^{200}$ They may even be competing against the archives of their own best performances. When the costs of using live performers are weighed against license fees to use recordings, it is no wonder that recorded performances have largely replaced live performers in the American experience. Live performers need salaries, health benefits, travel, hotel, and meal reimbursement, and they get

\footnotetext{
${ }^{197}$ A Listing of movie budgets and domestic and international gross revenues appears at http://www.thenumbers.com/movies/records/allbudgets.php. See also Patrick Goldstein, The Big Picture, Why Everyone Lies About Their Movie’s Budget, http://latimesblogs.latimes.com/the_big_picture/2009/01/why-everyone-li.html (Jan. 5, 2009), which explains the unreliability of movie budget data. See also Michael Cieply, A Movie’s Budget Pops from the Screen, N.Y. TimES, Nov. 9, 2009 (reporting on the anticipated release of the newest James Cameron film, Avatar, with a "price tag approaching $\$ 500$ million . . . . [p]ublished reports have put the production budget at more than $\$ 230$ million . . . . [w] [wen global marketing expenses are added, 'Avatar' may cost its various backers $\$ 500$ million”).

198

199

200 See generally Christopher Milazzo, Note, A Swan Song for Live Music?: Problems Facing the American Federation of Musicians in the Technological Age, 13 HOFSTRA LAB. L.J. 557 (1996).
} 
sick, lost, miss connections, and have substance abuse problems. If the public subsidy for symphony halls and opera houses were eliminated, even our largest metropolitan areas would likely cease supporting the elite musicians who perform there. As it is, most live performers in any field maintain an itinerant lifestyle, touring constantly to earn a living; and these are the luckiest of the most talented ones.

The tradeoff has changed dramatically since the late nineteenth century. Then, to hear music required live performers, and even the finest performers could appear in only one place at a time. Musicians of the second and third ranks and even far below these could make reasonable livings as professional musicians, especially compared to the alternatives available to the ordinary working person. ${ }^{201}$ Wherever people gather and hear recorded music, in restaurants, movie theaters, cafes, clubs, weddings, and receptions of whatever kind, they used to rely upon live musicians, and all these events contributed to performers' incomes.

Now few public performances of recorded music directly contribute to the livelihoods of professional musicians. Local bands maintain a subsistence level of living by performing "covers" of popular tunes, but most music heard everywhere is recorded, and these performances typically increase the royalty streams for copyrights owned by composers. Recordings publicly performed through digital audio transmission contribute a very modest amount to the performers recorded, although they typically own no interest in any copyrights. ${ }^{202}$ Under relatively standard terms of recording agreements, composers retain ownership of their copyrights in any musical

\footnotetext{
${ }^{201}$ See KenNEY, supra note 108, at 10, 37-63, 66-69. Although Kenney’s work examines a time when recordings of music were already common, the limited employment opportunities open to African Americans roughly approximate the limited mobility of several decades earlier. Work as professional musicians on the river provided upwardly mobile employment far better than laboring on the docks. See id. at 37-63, 66-69.

${ }^{202}$ Digital performance royalties, which includes payments to the copyright owners of sound recordings, usually the record label involved, rose from \$6.9 million in 2004 to $\$ 81.8$ million in 2008, still less than $1 \%$ of the retail value of digital and physical sales. RIAA, supra note 135.
} 
works they create and perform as recording artists. ${ }^{203}$ Corporations whose core strengths include the distribution and marketing of recordings garner the bulk of the revenues generated by the sale of recorded music. ${ }^{204}$ Revenues are no longer being divided between creative collaborators, composers, and performers as they were in 1897. Instead, business firms claim most. These firms, at their best, might serve a vital role in identifying, nurturing, and promoting gifted performers and then preserving their art for posterity, but if we credit the complaints of the artists themselves, these firms more often stifle innovation and seek to minimize financial risks by copying past successes in formulaic productions and manipulating consumer preferences with expensive promotion and marketing campaigns. ${ }^{205}$

Even nominally lucrative recording contracts provide far fewer benefits to musicians than commonly believed. Standard recording contracts authorize the record company to recoup all advances to performers, as well as any recording and independent promotion costs, as well as any expenses paid on behalf of the performer, solely from the performers' share of royalties, which typically approximates 12 percent. $^{206}$ (For this reason, record labels can earn large profits on recordings that never recoup their performers’ advances.) Performers under recording contract typically receive an advance against their royalties on copies sold of the recordings. ${ }^{207}$ They also engage and must compensate personal managers, business managers, agents, and legal counsel. From their advance, performing artists pay recording costs, studio time, musician

\footnotetext{
${ }^{203}$ Donald S. Passman, All You NeEd to Know About the Music Business 215 (6th ed. 2006).

${ }^{204}$ Id. at 94 (illustrating a hypothetical record deal for a "gold" selling album (500,000 albums sold) by a new artist, which generates over $\$ 6$ million in total sales at the wholesale level, of which the artist receives about $\$ 100,000$ ). 205

${ }^{206}$ See FISHER, supra note 149, at 19-20 (“[T] [e recording artists’ 12 percent share substantially overstates the amount that actually ends up in their pockets.” (citation omitted)). See also PASSMAN, supra note 203, at 80.

${ }^{207}$ See PASSMAN, supra note 203, at 78. Fewer than ten percent of record deals ever earn out their royalty advances. See Andrew Leyshon et al., On the Reproduction of the Musical Economy After the Internet, 27 MedIA, CulturE \& SoC'Y 177, 186-87 (2005) (stating that in global music sales "it is estimated that no more than 10 percent of records sold actually recoup the money the record company invests in its production . . . includ[ing] advances to artists, and the costs of recording, distribution, marketing and advertising”).
} 
salaries. For most, the advance is the only compensation from the recording. A very large number of recordings must be sold before additional royalties become due. Even recordings that sell well enough to allow recoupment of all the label's current expenses still rarely provide additional royalty income to performers. Standard recording contracts commit performers to seven albums. ${ }^{208}$ Any unfulfilled recoupment on earlier albums becomes an obligation of the subsequent ones and vice versa, so unless a performer's first albums are wildly successful, unrecouped obligations on subsequent or previous recordings usually will exceed current royalty revenues. While under these circumstances additional sales provide no additional benefit to performers, they remain profitable for the recording company. Record labels receive the balance of the 88 percent of revenues (assuming a 12\% performer's royalty and that the record labels also acts as the record distributor) after subtracting the retailers share (39 percent) and any royalties owed to music publishers (typically approximating 4 percent) owning copyrights for musical works performed on the album. ${ }^{209}$ Only if performers also composed the music recorded do record sales generate revenues not traditionally used to recoup their advances from record companies. Mechanical royalties and public performance royalties are paid directly to composers by (respectively) the Harry Fox Agency and the performing rights organizations (ASCAP and BMI). Purely in their role as performers, few musicians see any revenues beyond their initial advances.

\section{Performers Cannot Compete with Recordings}

\footnotetext{
${ }^{208}$ See PATRICK BurKart \& TOM MCCOURT, DigitAl Music WARs: OWNERSHIP AND CONTROL OF THE CELESTIAL JuKEBox 20 (2006). Donald Passman maintains that "[companies] insist on the right to get a total of five to six albums over the course of the deal. This is an improvement over recent years-companies used to insist on options for eight to ten albums." PASSMAN, supra note 203, at 96.

${ }^{209}$ See FISHER, supra note 149, at 19-20.
} 
On an economic basis live performances before live audiences ${ }^{210}$ can no longer compete with recordings except in narrow circumstances. The expense of attending live performances greatly exceeds the cost of equivalent recordings. ${ }^{211}$ It is also far less convenient. In the age of the Ipod, audio and video recordings have come to epitomize convenience and portability, capable of being played anytime and anywhere. Earlier technological innovations featured greater use of live performances than subsequent ones. Prior to World War II, radio broadcasts often featured live bands and orchestras. ${ }^{212}$ Except for talk radio, recordings have replaced these. Radio also once featured live dramas, comedies, soap operas, and adaptations from motion pictures. $^{213}$ Television too, at its inception also featured live musicians as well as live dramas and comedy sketches, ${ }^{214}$ but live television, aside from sports, some newscasts, and special events, is almost nonexistent today.

Live performance has even lost the advantage of sonic quality. Digital recording and reproduction is now so accurate that only the most discerning listeners care about the difference in sound quality between live and recorded performances. ${ }^{215}$ Even the distinction between them has become increasingly blurry. Because many live performances (some operas excepted) are

\footnotetext{
${ }^{210}$ I include what might first appear as a redundant use of "live" to distinguish recordings made in the presence of live audiences.

${ }^{211}$ The real costs of recordings have declined over time. Russell Sanjek cites the costs of shellac 78 rpm discs with six to seven minutes of playing time on two sides at $\$ 2.00$ a record in the early thirties. SANJEK, supra note 132, at 120. P2P may be free.

${ }^{212}$ See id. at 77-78 ("Bandleader Vincent Lopez was the first to appear with an orchestra on radio, when he led a studio recital from station WJZ, Newark, New Jersey, in November 1921.”).

${ }^{213}$ See Old-Time Radio, http://en.wikipedia.org/wiki/Old-time_radio (last visited Aug. 29, 2008).

214

${ }^{215}$ Younger generations of listeners, preferring portability to fidelity, listen to compressed audio files over tiny computer speakers or ear buds. This has changed "the way albums are produced, mixed and mastered - almost always for the worse. ... [B]y applying dynamic range compression, which reduces the difference between the loudest and softest sounds in a song. ... [Engineers] obscure sonic detail, rob music of its emotional power, and leave listeners with what engineers call ear fatigue.” See Robert Levine, The Death of High Fidelity, In the Age of MP3s, Sound Quality Is Worse Than Ever, ROLLING STONE, Dec. 26, 2007, available at http://www.rollingstone.com/news/story/17777619/the death_of high_fidelity. "And today listeners consume an increasing amount of music on MP3, which eliminates much of the data from the original file and can leave music sounding tinny and hollow.” Id.
} 
electronically amplified, the same loud speaker systems that might reproduce recorded

performances on one occasion transmit live performances on another, so the sonic signature of

live performance for many musical genres comes very close to that of recordings. ${ }^{216}$ Some

performances of popular music, while taking place in front of live audiences, are in fact recorded

performances and must be simulated as live performances because the physical exertions

required to accomplish the choreographed movements of the performer are incompatible with the

breath control required for accurate singing. ${ }^{217}$ Other performers have come to rely on the

electronic manipulations of their recorded performances to correct deficiencies in pitch, tone, and

rhythm and would disappoint their fans if they exposed them to their unprocessed voices and

music. ${ }^{218}$ With the advantages of cost and convenience and no deficiencies in sound quality, few

\footnotetext{
${ }^{216}$ The comparison is limited to the sound quality. Recordings lack the visual and interactive dimensions of live performance, which creates a different experience.

${ }^{217}$ See Chris Heard, Pop Fans Get That Synching Feeling, BBC News, available at http://newsvote.bbc.co.uk/mpapps/pagetools/print/news.bbc.co.uk/2/hi/entertainment/3670347.stm ("It seems some of the [pop] chart's more choreographed pop acts have accepted they cannot jump around stage and sing pitchperfect at the same time.”). Singing along to previously recorded music is so prevalent that reactions have moved beyond fans to music unions and even governments. See Musicians’ Union: Read Our Lips, L.A. Times, Feb. 4, 2006, available at http://articles.latimes.com/2006/feb/04/entertainment/et-quick4.2 (“Britain’s Musicians' Union has called on performers to come clean: Audiences should be told if those in the spotlight are lip-synching rather than singing.”). See also Australia Officials Warn Fans of Britney Spears Lip Synching, TRANSwORLD NEWs, Nov. 6, 2009, at 9, available at http://transworldnews.com/NewsStory.aspx?id=137135\&cat=2 ("Virginia Judge, the Minister for Fair Trading for New South Wales, released a statement warning fans that Spears has pre-recorded segments in her concerts.... She is considering Disclaimers indicating that portions of the shows will be prerecorded be required on promotional materials and tickets.”).

218 "Auto-Tune is a proprietary audio processor created by Antares Audio Technologies that uses a phase vocoder to correct pitch in vocal and instrumental performances. It is used to disguise inaccuracies and mistakes, and has allowed many artists to produce more precisely tuned recordings." Auto-Tune,

http://en.wikipedia.org/wiki/Auto_tune (last visited July 28, 2009). "Country stars Reba McEntire, Faith Hill and Tim McGraw have all confessed to using Auto-Tune in performance, claiming it is a safety net that gurarantees a good performance.” Auto-Tune, supra (citing Christopher John Treacy, Pitch-Adjusting Software Brings Studio Tricks, Boston Herald, Feb. 19, 2007, at 32). "The Auto-Tune Vocal Effect is what is technically known as 'pitch quantization.' Instead of allowing all of the small variations in pitch and the gradual transitions between notes that are a normal part of singing, the Auto-Tune Vocal Effect limits each note to an exact pitch, stripping out any variation, as well as forcing instantaneous transitions between notes.” Antares,

http://www.antarestech.com/products/auto-tune-efx.shtml (last visited July 28, 2009). Similar manipulation can be accomplished with drum rhythms. Beat Detective, a software product of Pro Tools, enables "the meticulous chopping of drum tracks into multiple slices so that timing can be adjusted and corrected." See Simon Price, SOS (SOUND ON SOUND), Aug. 2003, available at http://www.soundonsound.com/sos/aug03/articles/protoolsnotes.htm?print=yes.
} 
people besides professional performers and their supporting staffs have much exposure to live music on a regular basis.

Recordings even can surpass live music's sonic quality, because the venues that which feature many genres of live music suffer from significant ambient noise. Symphony orchestras may play in hushed concert halls, but jazz, blues, rock, and country performers play in clubs and bars against a background of ringing cash registers, clinking ice, and the frequently loud conversations of raucous fans. Major touring rock bands often appear in stadiums or other gargantuan spaces that, despite impossible acoustics, do little to dampen their fans' enthusiasm.

As with live music, few people attend live theater any longer, and when they do recordings play a larger role. Broadway Theater has increasingly replaced live orchestras in musicals with recordings because recordings are cheaper and do not get sick or go out on strike. There is a decades' long losing struggle by musicians unions to preserve live music performances by their members. ${ }^{219}$ Even when using live musicians, Broadway shows have reduced their numbers by using synthesizers. ${ }^{220}$

Recordings of comedies and dramas, viewed in movie theaters and on television, are far cheaper than live theater and much more convenient. With high definition video, currently available for broadcast and cable television and which has recently become available on DVDs,

\footnotetext{
${ }^{219}$ See generally Vern Countryman, The Organized Musicians: I, 16 U. CHI. L. REV. 56 (1948) (examining the history and activities of the American Federation of Musicians and the competition to its objective of obtaining higher wages and employment for its members from, i.e., military bands, foreign musicians, and amateur performers); Vern Countryman, The Organized Musicians: II, 16 U. CHI. L. REV. 239 (1949) (detailing the American Federation of Musicians' battles against the technological competition of motion pictures, phonographs, radios, jukeboxes, and television); Robert A. Gorman, The Recording Musician and Union Power: A Case Study of the American Federation of Musicians, 37 Sw. L.J. 697 (1983); and Milazzo, supra note 200 (highlighting the unique threat to musicians posed by synthesizers and digital audio tape).

${ }^{220}$ See, e.g., Donald G. McNeil Jr., New Show Is First Not to Have to Pay Idle Musicians, N.Y. Times, Feb. 8, 1995, at C13. See also Milazzo, supra note 200, at 566 n.77, 580 (noting the use of taped music on Broadway and countering the argument that enjoyment of live performances ensures that musicians will not be replaced by unlimited technology by asserting that on Broadway "the musicians are not the main attraction").
} 
both the sound and visual quality of visual recordings will receive a substantial boost. Even ordinary analogue broadcast television compares favorably with live theater in terms of visual and audio clarity. Audiences at live performances must contend with distant seats and sometimes experience difficulty with seeing or hearing the details of the performance. Movies and television use telescopic lenses to provide the visual details that distant viewers could never perceive, and boosting volume controls usually solves any problems with inaudible soundtracks (and besides, DVDs come with subtitles). Surround sound and other computer controlled acoustic programs can also approximate much better seats than the typical theater fan can afford. Attending theaters requires making reservations, purchasing tickets, transportation, parking, and often arranging child care for young children. We can play movies and television program recordings on an increasing number of inexpensive and portable devices, some small enough to carry in a pocket and take anywhere, offering a larger measure of convenience. Live performances struggle to compete with recorded ones.

While theater actors get paid (weekly) for each ephemeral performance, ${ }^{221}$ recorded dramas, as with music recordings, force performers, and the other creative workers who collaborate in their production, to compete with the accumulated past history of all recorded dramas (or music) including their own previous recorded performances. Provoked by this prospect in the 1950s, when the movie studios began the transfer of theatrical motion pictures to commercial television, the unions and guilds ${ }^{222}$ representing certain performers and professionals responded by negotiating collective bargaining agreements providing for the payment of

${ }^{221}$ See Actors' Equity Ass'n R. 63 (I), http://www.actorsequity.org/docs/rulebooks/Production_Rulebook_League 04-08.pdf. See also Actors' Equity Ass'n, Standard Minimum Production Contract § 4. Simensky, Slez, BuRnETt, Lind \& Palmer, EnTERTAinMENT LAW: DOCUMENT SUPPLEMENT (2d ed. 1999) (Form 45).

${ }^{222}$ The unions and guilds involved were the American Federation of Musicians (AFM), the American Federation of Television and Radio Artists (AFTRA), the Directors Guild of America (DGA), the Screen Actors Guild (SAG), and the Writers Guild of America (WGA). See Paul \& Kleingartner, supra note 124, at 665. 
residuals. ${ }^{223}$ The unions and guilds were concerned that this transfer would provide an alternative to the production of new material and reduce future employment opportunities. ${ }^{224}$ For a small and elite group of actors and other creative professionals, individually negotiated personal service contracts require payment of additional contingent compensation, often far in excess of minimums established through collective bargaining, but most collaborators in the production of recorded dramas can rely only on their residual rights in recorded performances derived from collective bargaining agreements negotiated by their unions. ${ }^{225}$ For some actors, residuals can be substantial. Data from the Screen Actors Guild suggests "an inverse relationship between an actor's total income and the proportion of that total contributed by residuals."226 Outside of the film and television industries where powerful unions have developed compensation structures that still reward performers when recordings of their performances substitute for additional new live performances, performers must otherwise recoup all economic benefit from their performances with their "first sale." It is as though copyright did not even exist, since, unless they are also authors, i.e., copyright owners, it effectively does not.

Computer animation threatens to make the livelihoods of actors even more precarious. Not only must they compete against recordings, but with animation they, like the mythic John Henry, must compete against machines, whose ever increasing speed and power threaten to dispense with their services entirely. Already, video games have become serious competition for

\footnotetext{
${ }^{223}$ See id. at 669 . "Residuals ... are additional payments to workers for the exhibition of an entertainment product in media other than the one for which it was originally created, or for its reuse within the same medium subsequent to the initial exhibition." Id.

${ }^{224} \mathrm{Id}$.

${ }^{225} \mathrm{Id}$. at 668 .

${ }^{226} \mathrm{Id}$. at 672. "Among feature film actors (nearly all of whom are highly paid under personal services contracts) the ratio of initial compensation to residuals is about 6 to 1 . Among television actors (who work under a mix of personal service contracts and minimum wage guarantees), initial compensation is about twice as large as residual income. In television commercials, nearly all of whose actors receive minimum scale, residual compensation is four times as great as initial session fees. ... [T] he total residual compensation from all markets is approximately equal to total initial compensation.” Id.
} 
the motion picture and music industries. ${ }^{227}$ Since consumers have only so much time and money, all the entertainment industries compete for the same dollar. Video games can dispense with live actors entirely, although many use live actors to record dialogue for the audio portions of the games. ${ }^{228}$ As animation technology improves and personal computers become more powerful, the richness of detail of game characters will approach that of the images of real actors. At present, however, facial animation creates a significant stumbling block. ${ }^{229}$ We humans attune so unconsciously to such fine gradations of facial expressions that we cannot accept animated faces that closely approximate real ones, even though we readily accept the physical gyrations of animated bodies as real. ${ }^{230}$ When faces can be realistically animated, live actors will become obsolete even for major studio productions of conventional scripts. ${ }^{231}$ Perhaps a few celebrity actors with an active fan following will retain economic viability as a kind of brand or trademark identity. Movie and television executives might still want to use their recognizable facial features in their productions, but a single digital photograph will suffice for sufficient "real" raw material for their digital manipulations. Movie makers will no longer

\footnotetext{
${ }^{227}$ In 2008 U.S. computer and video game sales rose to $\$ 11.7$ billion; movie box office revenues rose to $\$ 9.8$ billion (domestic); and record sales fell to \$8.5 billion. MOTION PICTURE Ass’N OF AM., supra note 124; RIAA, supra note 135; http://www.theesa,com/facts/salesandgenre.asp.

${ }^{228}$ See Seth Schiesel, A Video Game Star and His Less-Than-Stellar Pay, N.Y. TimES, May 21,2008, available at http://www.nytimes.com/2008/05/21/arts/television/21gta.html? r=2\&sq=niko\&st=nyt\&scp=1\&pagewanted=print \&oref=slogin\&oref=slogin (reporting the complaint of actor, Michael Hollick, whose voice acting and motioncapture work provided the voice and movement for the star character in Grand Theft Auto IV). Mr. Hollick received $\$ 100,000$ for 15 months work and receives no royalties or residuals. The game generated $\$ 600$ million in sales in the first 3 weeks of its release. In justifying why the compensation structure of video games differs from that of the motion picture and television industries the reporter explained that "games almost never highlight the people behind the digital characters, and almost no one buys a game based on which actors are in it.” Id.

${ }^{229}$ FRÉDÉRIC PIGHIN ET AL., INT’L CONFERENCE ON COMPUTER GRAPHICS \& INTERACTIVE TECHNIQUES, SYNTHESIZING REALISTIC FACIAL EXPRESSIONS FROM PHOTOGRAPHS (2006), available at http://research.microsoft.com/pubs/68336/Pighin-SG98.pdf); YuENCHENG LEE, DEMETRI TERzOPOULOS \& KeITH WALTERS, REALISTIC MODELING FOR FACIAL ANIMATION 55-62 (1995), available at 10.1145/218380.218407 (proceedings of the 22nd annual conference on Computer graphics and interactive techniques).

${ }^{230}$ PIGHIN ET AL., supra note 229, at 1. ${ }^{231} I d$.
} 
require such actors to actually perform. ${ }^{232}$

Book authors have confronted competition from past authors ever since writing became

the first technology of recording. Before printing they faced this competition more in theory

than in fact. Large library collections were rare, expensive, and inaccessible. ${ }^{233}$ Until little more

than a century ago, the author's public reading of his books was an important source of income.

At the mid-nineteenth century, the lecture circuit, a type of live performance, provided the bulk

of the income for book authors:

The centrality of the lecture in the formation of American culture has yet to gain the appropriate attention of scholars, despite the fact that writers, no matter their field, were able to gain more cash from lecturing than from book publication and often, like Mark Twain, viewed the former as a way of achieving the latter. ${ }^{234}$

The unity of author and performer limited competition to whatever authors were alive and

present in the locality. But today, in the era of the Internet, Amazon.com, Federal Express, and

Google Books Library Project (Google Book Search), ${ }^{235}$ that competition against the cumulative

${ }^{232}$ Animation is also a two-edged sword. While it allows producers to dispense with live actors, it also allows authors to escape the economic demands of those same actors as well as the constraints of physical reality. It would allow movie authors to dispense with the large scale production organizations required to produce a feature film. It would restore to primacy the movie author, who may in the future have the capacity to create a movie solely with the aid of computers and without other participants, just as authors need no one else to create novels.

233 See generally JAMES WESTFALL THOMPSON, THE MEDIEVAL LIBRARY (1939). Although certain historical events such as the "decay of the monasteries" changed the nature of libraries, it was not until the invention of the printing press that this change took shape on a grand scale. Id. at 372. As Thompson exudes:

[T] he printing press . . . was invented for the production of books on a scale never dreamed of and never possible in the scriptorium. The political historian cites great events like the capture of Constantinople by the Turks in 1453, the discovery of America in 1492, and the French invasion of Italy in 1494 as "key" events which terminated the Middle Ages, and, like hinges, swung Europe into the arc of modern times. But to the student of culture no event was so significant and so fraught with importance as the invention of movable type.

Id.

${ }^{234}$ Buckley, supra note 160, at 1611, 1622.

${ }^{235}$ Google is in the process of creating a global book repository by digitizing every book that has ever been published through the help of libraries and publishers. Several major libraries have agreements with Google so that their collections are searchable online. Works still in copyright may display only a few sentences of text surrounding search terms, but for works whose protection has expired, the entire text is available. See MICHAEL Miller, Googlepedia: The Ultimate Google Resource 475-88 (2007). See also Robin Jeweler, The GoOgle BoOK SEARCh Project: Is OnLINe IndeXING A FAIR UsE Under Copyright LAw? (Cong. Research Serv., CRS Report for Congress Order Code RS 22356, Dec. 28, 2005), available at 
past has arrived at the fingertips (poised over a keyboard) of anyone with an Internet connection. All modes of expression have begun to resemble the circumstances of books in the Internet age. We should rethink the exclusive bundle of rights granted by copyright to restore the social experience to copyright.

\section{E. Restructuring Copyright for a Social Species}

Since 1909 technological innovation has given us convenient and inexpensive access to almost the entire recorded history of the world's cultures, a not unmitigated blessing. But perhaps copyright policy should deliberately resist this trend because technological innovation it has also helped eliminate the social context in which we once experienced our culture.

Conceivably this elimination might be a good thing, but we know too little about ourselves or the functions expressive culture serves to blithely accept it as an unexamined consequence of technological innovation. We are fundamentally a social species and recognition of this aspect of ourselves should rightly inform copyright policy.

Restructuring copyright to make it more suitable for a social species implies a reduction in the scope of its monopoly. Does this risk a decline in innovation? Does this risk the potential future of our cultural heritage? Too much has been made of the incentive granted by an ever expanding monopoly. The United States achieved world dominance in expressive culture, much to the annoyance of the rest of the world, with the hyper technical 1909 Act, which granted much weaker property rights than either those granted in Europe or by our own 1976 Act. Even with the current greatly expanded scope of protection, innovation has continued to occur outside of the copyright system. So cutting back a few of these expanded grants risks little or no innovation, and might well reduce constraints on innovation, while at the same time creating a 
legal environment more compatible with our social nature as a species.

A subsequent section will consider sources of creative innovation outside the copyright system and will address concerns about cultural vitality if we restrict the scope of copyright. The section immediately following assesses the creative process in order to identify which of the six exclusive rights granted by copyright have the most significance for the social creation and consumption of expressive culture. In succeeding sections the analysis will suggest how constraints on the scope of the copyright monopoly might align copyright policies more with the needs of our social species. To achieve this realignment, I propose reducing the exclusivity of only two of these rights. Why should all six exclusive rights granted by copyright have the same term and scope of protection? Some rights have far more significance for the social experience and creation of expressive culture than others. Shortening the term of the derivative work right and restricting the scope of the public performance right in musical works would achieve the necessary policy objectives. The other rights can retain their current (unreasonably) lengthy terms.

\section{Limiting the Public Performance Right of Musical Works. - The current public} performance right applies whenever the performance is public. ${ }^{236}$ The statute makes no differentiation among the various types of possible public performances. ${ }^{237}$ A live performer

${ }^{236} 17$ U.S.C. § 101 (2006):

To perform or display a work "publicly" means-

(1) to perform or display it at a place open to the public or at any place where a substantial number of persons outside of a normal circle of a family and its social acquaintances is gathered; or

(2) to transmit or otherwise communicate a performance or display of the work to a place specified by clause (1) or to the public, by means of any device or process, whether the members of the public capable of receiving the performance or display receive it in the same place or in separate places and at the same time or at different times.

${ }^{237}$ The statute does distinguish among the types of work involved, as this proposal does. The current statute grants no public performance rights to sound recordings (as distinct from the underlying musical work) unless the performance is by digital audio transmission, thus exempting analogue radio broadcasts. See id. § 106(6). 
before a live audience implicates the same right as merely playing a recording for the same audience. The same right applies even if the listening audience is not gathered together in one place but is dispersed in place or time. If the social experience of public performance works animated copyright policy, then this uniform treatment would change, because it neglects the widely divergent experiences of these variant “audiences.”

Performance rights should vary by the nature of the audience's experience. To enhance audience experience, copyright policy should seek to reduce the competitive cost advantage of recordings over live performance in order to encourage more live performance. Unless it is being recorded, a live public performance of a musical work should fall outside the scope of the public performance right. Making such performances royalty free encourages live performances, offering the potential of creative interaction between performers and audience. ${ }^{238}$ Eliminating monetary payment provides an obvious benefit, but the more significant benefit might well prove to be the elimination of the transaction costs (time, legal, and administrative efforts to obtain licenses for particular works or venues), which would allow both spontaneous selection of material, a critical factor in the creative process, and opportunistic use of performance venues.

The immediate audience response provides uniquely valuable criticism that recording studios and music industry executives cannot provide. A live performer with a live congregated audience is immersed in the social interaction of the audience response, which probably approximates the evolutionary milieu which generated our need to make musical works.

Favoring the social experience of works is not totally alien to the Copyright Act. Even

\footnotetext{
${ }^{238}$ Currently, § 110(4) exempts live amateur and free performances of nondramatic literary works or musical works. See id. § 110(4). Prior to the invention of recording technologies, amateur performance offered the predominant way to experience much of our expressive culture. Amateur musical groups performed for themselves or an audience drawn from their immediate community or social networks, and book groups engaged in public readings of the leading works of their day. The existing exemption encourages social consumption of our expressive culture. Such performances are artifacts from a vanished era, but with certain modifications, we could create more effective incentives to encourage such performances.
} 
the 1976 Act contains some limited incentives for social consumption. Two of the limited exemptions from infringement liability in $§ 110$, teaching ${ }^{239}$ and religious worship, ${ }^{240}$ can be justified as recognition of the social context in which works are experienced during these activities. The teaching exemption applies only to performances or displays in "face-to-face teaching activities" and the religious exemption covers only performances or displays "in the course of services at a place of worship or other religious assembly.” In the exempt context participants must socially interact, and the resulting benefits they receive reflect both this interaction as well as the consumption of the copyrighted work. The benefits derived from these dual sources could be deemed to outweigh the economic loss to copyright owners created by the exemptions. In a teaching environment the learning experience depends upon the conflicts, contrasts, and comparisons that derive from the competing and disparate perceptions, understandings, and interpretations of the work experienced by the learning group. In the religious context the communal shared experience of participatory worship is largely the point of the experience. Participants do not experience the expressive work for its own sake, but as an instrument to achieve their educational or religious purposes. In some respects these exemptions are analogous to fair use exemptions. The contributions of the participants to their experience of the works create social benefits ${ }^{241}$ above and beyond the unmediated value of the work alone.

Changing the public performance right as proposed above would reverse more than a century of music practice, but it would not venture into alien policy territory. Only with the

\footnotetext{
${ }^{239}$ See id. § 110(1)-(2).

${ }^{240}$ See id. § 110(3).

${ }^{241}$ Other $\S 110$ exemptions benefit nonprofit or voluntary groups by indirectly subsidizing their charitable activities, and if these promote social cohesion, then the exemptions support this effort too. Section 110(10) exempts performances of nondramatic literary or musical works in the course of social functions organized and promoted by nonprofit veterans organizations or nonprofit fraternal organizations to which the general public is not invited, if the proceeds are used exclusively for charitable purposes and not for financial gain. Id. § 110(10). Section 110(6) exempts performance of nondramatic musical works by a governmental body or nonprofit agricultural or horticultural organization in the course of an annual fair or exhibition. Id. § 110(6).
} 
1897 amendments did the public performance of musical works come within the exclusive copyright grant. ${ }^{242}$ It took a further two decades for the courts to establish that the "for profit" requirement did not necessitate a separate admission charge for music to find infringement. ${ }^{243}$ Constraining the public performance right in this way would return copyright restrictions on music to an era that still managed to birth ragtime, the blues, rhythm and blues, rock, and jazz. This change would have little effect on the incomes of composers, since the public performance of recordings generates most of their incomes from the public performance right. As in the era before recordings, they would still receive royalties from the (increased) sales of sheet music necessary for live performers to learn their music. This seems a small price to pay to adapt copyright to our social species.

2. Requiring Fixation to Infringe the Derivative Work Right. - A second and even more modest reform effecting even less change to existing doctrine, requiring little more than a clarification, would require fixation ${ }^{244}$ to infringe the derivative work ${ }^{245}$ right. An unfixed derivative work can rarely substitute for or supplant demand for the underlying work. Successful and free experimentation with a variety of underlying source materials for derivative works might well lead to a subsequent fixed derivative work for which royalties would later become due. The derivative work might be all the better for the period of royalty free experimentation in unfixed forms, which would allow authors to incorporate improvements and refinements derived from live audience responses. Investments in licenses for fixed derivative works might increase

\footnotetext{
${ }^{242}$ See Act of Jan. 6, 1897, ch. 4, § 4966, 29 Stat. 481, 481-82 (current version at 17 U.S.C. § 106(4) (2006)).

${ }^{243}$ See Herbert v. Shanley Co., 242 U.S. 591, 593-95 (1917).

244 "A work is 'fixed' ... when . . . [it] is sufficiently permanent or stable to permit it to be perceived, reproduced, or otherwise communicated for a period of more than transitory duration.” 17 U.S.C. § 101 (2006).

${ }^{245}$ A 'derivative work' is a work based upon one or more preexisting works, such as a translation, musical arrangement, dramatization, fictionalization, motion picture version, sound recording, art reproduction, abridgement, condensation, or any other form in which a work may be recast, transformed, or adapted. A work consisting of editorial revisions, annotations, elaborations, or other modifications which, as a whole, represent an original work of authorship, is a 'derivative work.'”
} 
because the royalty free period of experimentation and development with unfixed derivative works would reduce the uncertainty of audience demand for the work, allowing more accurate estimates of commercial value. The current system requires obtaining a license (advisedly) before creating even unfixed derivative works, forcing the choice of the underlying work and the amount of monetary commitment before actually using the work and gauging its potential artistic or commercial success from the response of a live audience. These proposed changes would free the live performance of music and other categories of works to draw upon the entire body of existing works as source material so long as the newly created derivative works remained unfixed. $^{246}$

We need only clarify existing doctrine to eliminate liability for unfixed derivative works, since considerable authority already exists for the interpretation that unfixed derivative works do not infringe. Doctrinal ambiguity arises because “[a] work is 'created' when it is fixed in a copy ....,247 Since "[a] 'derivative work' is a work,"248 the statutory definition strongly implies that to infringe the derivative work right the infringing work must be fixed. ${ }^{249}$ Unfortunately, the legislative history of the 1976 Act explicitly contradicts this implication by stating that no fixation is required to infringe the derivative work right. ${ }^{250}$ The courts have failed to resolve

\footnotetext{
${ }^{246}$ Live broadcasts of performances with a live studio audience would in theory be permitted, but these have become rare in contemporary broadcasting practice. Because of time zones, very few broadcasts are likely to be completely unfixed, since the economics of broadcast schedules create strong incentives for repeated broadcasts so that the same time schedules can be maintained in different time zones.

24717 U.S.C. § 101 (2006).

${ }^{248}$ Id. (emphasis added).

${ }^{249}$ See 2 NiMMER ON COPYRIGHT, supra note 164, § 8.09[A] (2006).

${ }^{250}$ See H.R. REP. No. 94-1476, at 62 (1976), as reprinted in 1976 U.S.C.C.A.N. 5659, 5675 and S. REP. No. 94-473, at 58 (1975) (emphasis added):

Preparation of derivative works. - The exclusive right to prepare derivative works, specified separately in clause (2) of section 106, overlaps the exclusive right of reproduction to some extent. It is broader than that right, however, in the sense that reproduction requires fixation in copies or phonorecords, whereas the preparation of a derivative work, such as a ballet, pantomime, or improvised performance, may be an infringement even though nothing is ever fixed in tangible form.
} 
these conflicting possibilities. In dictum ${ }^{251}$ in Lewis Galoob Toys, Inc. v. Nintendo of America, Inc. ${ }^{252}$ the court pronounced that "[a] derivative work must be fixed to be protected under the Act, but not to infringe." It then proceeded to muddy this treatment of the fixation issue by declaring that "[a] derivative work [that infringes] must incorporate a protected work in some concrete or permanent form.”253 The statute, however, is unambiguous in its § 101 language, defining the moment a work is "created" as when it is "fixed," and a derivative work is necessarily a "work." Thus to infringe the derivative work right requires fixation of the infringing derivative work. Given this lack of ambiguity, one could resort to the well established interpretative rule that reference to legislative history for purposes of statutory interpretation is justified only when statutory language is ambiguous, ${ }^{254}$ and in the $\S 101$ definitions, there is no ambiguity to resolve.

Of course an unfixed derivative work could still infringe other exclusive rights. The public performance of an unfixed derivative work of an underlying musical work ${ }^{255}$ would still infringe the public performance right of the underlying work (assuming the derivative work is substantially similar to the underlying work), and to infringe the public performance right requires no fixation. To avoid this infringement, I argued in the previous subsection that the public performance right should exempt live performances before live audiences.

3. Shortening the Copyright Term for the Derivative Work Right. - Our culture and society changes rapidly, driven by the frenetic pace of technological innovation. In less than one

\footnotetext{
${ }^{251}$ It was dictum because the court ultimately concluded that the purported infringing work did not constitute a derivative work because it did not recast the plaintiff's work.

${ }^{252} 964$ F.2d 965, 968 (9th Cir. 1992), cert. denied, 507 U.S. 985 (1993).

${ }^{253} \mathrm{Id}$. at 969.

254 "Given the straightforward statutory command, 'there is no reason to resort to legislative history." United States v. Gonzales, 520 U.S. 1, 6 (1997). See also United States v. Fisher, 6 U.S. (2 Cranch) 358, 399 (1805).

${ }^{255}$ Fair use could rebut allegations of infringing the public performance right. If the unfixed derivative work varied substantially from the underlying work, the ephemeral nature of the unfixed work could be an additional (optional) factor in addition to the mandatory four factor $\S 107$ analysis that would weigh in favor of fair use.
} 
hundred fifty years our society has evolved from rural patterns of settlement and an agrarian economy, through urbanization and industrialization, to the current exurban sprawl and information services based economy. Expressive works undoubtedly play a role in enabling both individuals and society to adapt to the rapidity of technological and cultural change. In earlier eras change proceeded much more slowly, and in our prehistoric past—-the great bulk of time during which evolution has molded the human animal—change occurred at a glacial pace. Rapid change would seem to increase our reliance on culture and expressive works to help mediate the psychological stresses and social tensions created by such speedy transitions. The increasing pace of technological and cultural change implies a shorter term of copyright, not the ever lengthening one of present circumstances. ${ }^{256}$

Historically the arts have served as key interpreters of the human experience, helping us make sense of our lives, our environment, and our social relationships. For authors to create the works that fill this role, they need access to the immediate past and not just the distant past (roughly one hundred years and counting) for them to help make sense of our rapidly evolving contemporary experience. ${ }^{257}$ The cultural meaning of works created only a few decades ago now escapes contemporary audiences. The rigid political and sexual mores of Hollywood that constrained its subject matter throughout its heyday are incomprehensible to contemporary audiences. The current revival of interest in African-American music forms, from jazz to blues to do-wop, involves audiences listening to this music without hearing the racial caste divisions out of which this music grew and which often fueled its expression. ${ }^{258}$ Lengthy copyright terms

\footnotetext{
256

${ }^{257}$ Shortening the term of copyright would reduce the problem of orphan works.

${ }^{258}$ One of Billie Holiday's most famous and controversial songs was Strange Fruit, written by Abel Meeropol under the pseudonym Lewis Allan:

Southern trees bear a strange fruit,
} 
reduce the relevance of many works by the time they eventually enter the public domain and become freely available raw materials for subsequent authors. In an era of such rapid change, the less relevant the public domain becomes, the less value it has as raw material for subsequent authors. For copyright to play its proper cultural role, it must free more current raw material for use by contemporary creators.

Authors need access to our recent cultural past to help us make sense of our rapid cultural transitions. This factor argues for a short term of copyright so long as the otherwise protected material is used for a new work, a derivative work. How short? A range of ten to fifteen years would prove adequate. Very few works have commercial lives of greater length, ${ }^{259}$ and the rapid pace of cultural change warrants making as much as possible of our recent history available to future authors.

Shortening the term of the derivative work right might make senses as a policy matter. The difficulty lies in accomplishing this result as a doctrinal matter. The essential problem is

(Blood on the leaves and blood at the root,) Black body swinging in the southern breeze, Strange fruit hanging from the poplar trees.

Pastoral scene of the gallant South, (The bulging eyes and the twisted mouth,) Scent of magnolia, sweet and fresh, (And the sudden smell of burning flesh.)

Here is a fruit for the crows to pluck, For the rain to gather, for the wind to suck, For the sun to rot, for a tree to drop, Here is a strange and bitter crop. See, e.g., Howard Zinn \& Anthony Arnove, Voices of a People’s History of the United States 326-27 (2004).

259 "Even allowing for the optimism and self-confidence necessary in these creative and risky fields, the wildest dreams of artists and producers probably extend no farther than 'smash hit' status for their works for a year or two, and healthy sales for five or ten.” EDWARD RAPPAPORT, COPYRIGHT TERM EXTENSION: ESTIMATING THE ECONOMIC VALUES 4-5 (Cong. Research Serv., May 11, 1998). The same study found that only about $1 \%$ of book copyrights were renewed after their initial 28 year term. Id. at 6 . Given the compliance with onerous formalities necessary to secure federal copyrights during the period examined, a far lower proportion of protected works would have enduring value in the current copyright era of automatic protection upon fixation. 
that existing copyright doctrine fails to adequately distinguish the derivative work right from the reproduction right. Both require "substantial similarity" for infringement and the contours of the derivative work right are sufficiently vague that (for example) an unauthorized movie sequel could easily infringe both rights. The statutory definition speaks in general terms of a recasting, transformation or adaptation, but these terms provide no precise delineation of the parameters of the concept. In the abstract differentiating the two rights is probably not possible, but if we ask what purposes each right serves in the light of the social nature of our species, a basis for distinction may develop. Such an inquiry is beyond the scope of this current article and will be the subject of a subsequent paper.

\section{F. Implications for the Copyright Industries}

The current statute's very long term creates too great an incentive for the large entertainment conglomerates to seek out and rely upon potential blockbuster properties that can generate revenues from various derivative works for many decades. The dominant business model has led to the aggregation of a large number of specialized entertainment or media firms into a few giant entertainment conglomerates. ${ }^{260}$ Their common strategy relies upon exploiting

\footnotetext{
${ }^{260}$ The Columbia Journalism Review, founded in 1961 under the auspices of Columbia University's Graduate School of Journalism, operates an interactive website at http://www.cjr.org/resources/index.php?c=disney, which when a particular media company is selected, lists what it owns. The web address in the previous sentence provides an example for the Walt Disney Company.

"Time Warner is a leading media and entertainment company, whose major businesses encompass an array of the most respected and successful media brands. Among the Company's brands are HBO, TNT, CNN, AOL, People, Sports Illustrated, Time and Time Warner Cable. The Company produces and distributes films through Warner Bros. and New Line Cinema, including The Dark Knight, Sex and the City: The Movie, Get Smart, Journey to the Center of the Earth and the Harry Potter films, as well as television series, including Two and a Half Men, Without a Trace, Cold Case, The Closer and ER. During 2008, the Company generated revenues of $\$ 46.984$ billion (up 1\% from $\$ 46.482$ billion in 2007), Operating Loss of $\$ 15.957$ billion (compared to Operating Income of $\$ 8.949$ billion in 2007), Net Loss of $\$ 13.402$ billion (compared to Net Income of $\$ 4.387$ billion in 2007) and Cash Provided by Operations of $\$ 10.332$ billion (up $22 \%$ from $\$ 8.475$ billion in 2007).” Time Warner, Inc. Annual Report on Form 10-K, at 73 (2009), available at http://www.sec.gov/Archives/edgar/data/1105705/000095014409001481/g17605e10vk.htm.
} 
derivative works of particular copyright properties in a large number of mediums. ${ }^{261}$ For instance, an entertainment conglomerate can take a bestselling novel marketed by its publishing arm, use it to develop a screen play for a motion picture, with background music recorded by its record division, to be produced and distributed theatrically by its movie studio, create and exploit sequels and prequels, and then distribute all these works through its cable division and later broadcast them on its television network affiliate. ${ }^{262}$ Subsequently it might further develop the property for a broadcast or cable television series or a Broadway musical, or derive a video game from it and evolve the game into an on-line interactive gaming experience accessed through the portal website of its Internet division.

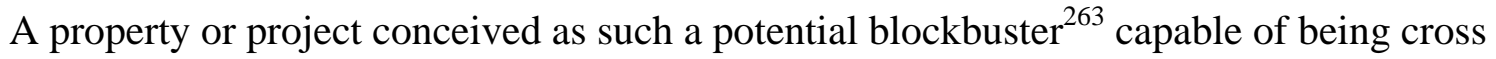
sold into many different markets through many different mediums must inevitably be formulated to appeal to the broadest possible audience. A broad appeal often translates into bland and formulaic projects, which to compensate often involve magnificent (and very costly) production values. This in turn leads to the neglect of projects whose initial appeal might appear far more limited. As currently structured, entertainment conglomerates can be risk adverse. They need not explore risky opportunities in new works or genres (truly risky ones as opposed to ones merely marketed as risky or "edgy”). With their large libraries of existing works, they can instead safely rely on profits from works created decades ago; they can revive Broadway

\footnotetext{
${ }^{261}$ Johnnie L. Roberts, Big Media, R.I.P., NEWSWEEK WEB EXCLUSIVE, May 5, 2009, http://www.newsweek.com/id/195961.

262 “[A]lthough there are many examples of musical 'assets' being used successfully in synergies with other cultural products, there is considerable pressure within media conglomerates to use them in relation to the conglomerate's other internal media assets, as if to justify the existence of the conglomerate, rather than to use them in combination with other cultural products that might be more appropriate but which lie outside the company in question ....” Leyshon et al., supra note 207, at 184.

${ }^{263}$ In 2008 the movie industry released 610 feature films in the domestic market. The top 20 grossing films accounted for $39 \%$ of total domestic box office revenues. Motion PicturE Ass’N OF AM., supra note 124, at 2, 6, 7.
} 
musicals as movie musicals, remake classic films or recordings, make prequels and sequels, өr digitize analogue works, or colorize black and white films. Creating movie franchises through the development of sequels and prequels to previous hit movies has proven to be an enormously successful financially. The Star Wars saga has produced six movies grossing $\$ 4.2$ billion; twenty-one James Bond films have generated $\$ 3.9$ billion; three Lord of the Rings motion pictures have produced \$2.9 billion; and so far the Harry Potter trilogy has generated \$2.6 billion in earnings. ${ }^{264}$ Drastically shortening the term of copyright for the derivative work right would force the copyright industries to seek out, support, and develop currently producing creators, whose newly created works would still come within copyright.

With a drastically shortened term for derivative works, copyright owners could still create sequels and derivative works and cross sell these into other markets, but their derivative works would face competition relatively soon from the derivative works of other creators with access to the same properties after the expiration of the newly abbreviated term of the derivative work right. Two competitive effects would result. First, many different interpretations of the same underlying work would compete for the public's attention—a healthy development.

Second, new technologies would create pressure on content owners to reissue old nuggets from their vaults in the new formats or watch competitors issue their own and reap the rewards of first comers. ${ }^{265}$ Depending upon the industry and technology involved, and taking the music industry as an illustrative example, owners of the underlying work, i.e, the master analogue recording,

\footnotetext{
${ }^{264}$ Ronald Grover, The Lion, the Witch, and the Franchise: Disney Is Counting on Narnia to Reel in an Audience of Kids, Gamers, and Christians, Bus. WK., Nov. 7, 2005, at 62, 64.

${ }^{265}$ This pressure would only arise if digitizing an analogue work were the kind of "transformation" which comes within the derivative work right. I propose to argue in a subsequent article that we should conceive the boundaries of the derivative work right to serve a larger purpose of copyright, the social experience of our expressive culture. In doing so, one candidate purpose might be to increase competition among media firms for new creative talent.
} 
would still have the ability to create the highest fidelity digitized derivative work. ${ }^{266}$ Digitizing a master recording should cost no more than one of lesser fidelity made from the music as commercially released, so master tape owners could offer the best fidelity for the same price as others. Since original producers have long since written off or amortized the initial production costs, any new revenues represent "found" money for the original producers, and price competition should not eliminate all incentives for digitization and distribution. But if, like many owners of analogue recordings and current owners of mammoth film libraries, these owners lag in converting and distributing their works in the new formats made possible by new technologies, then these laggards will lose to more nimble competitors issuing digitized works as derivative works, and these might be anyone with a lawful copy of the work in an existing format. Consumers will benefit from the chance to acquire works in new formats from firms that digitize old analogue works, even if the fidelity is somewhat less. ${ }^{267}$ Something similar already exists with respect to the mechanical license provision under the current Act. ${ }^{268}$ Using the compulsory license provision under this section, cell phone ringtone providers have distributed digitized snippets of musical works as ringtones and created a multibillion dollar industry. ${ }^{269}$ If consumers had had to wait for the major record labels or music publishing houses to recognize and enter this market, it might never have developed.

\footnotetext{
${ }^{266}$ Digital master recordings would provide less advantage to the record labels that typically own them.

${ }^{267}$ Illustrating the potency of consumer demand for established analogue works in new digital formats, a digitized Beatles reissue recording climbed to the number one position on the Billboard charts more than three decades after the group’s dissolution. See Keith Spera, Meet the Beatles! To Baby Boomers and Backstreet Boys Fans Alike, the Former Fab Four is the Hot "New" Boy Band, New Orleans Times Picayune, Mar. 10, 2001, at 1. The copyright owners could have further delayed reissues for many more decades under the current copyright regime. Between 1991 and 1998 the Disney Corporation generated more than \$360 million in revenues from the video format version of the movie Fantasia, initially released in 1940. See Boosey \& Hawkes Music Publishers, Ltd. v. Walt Disney Co., 145 F.3d 481, 485 (2d Cir. 1998).

${ }^{268}$ See 17 U.S.C. § 115(a) (2006). Ever since its enactment in the 1909 Act, this provision has fostered competition between different recorded versions of the same musical composition.

${ }^{269}$ See Mechanical and Digital Phonorecord Delivery Rate Adjustment Proceeding, 71 Fed. Reg. 64,303 (Nov. 1, 2006) ("The Register of Copyrights ... stat[ed], with certain caveats, that the statutory license applies to ringtones.").
} 
The use of a compulsory license provision introduced competition into a market niche previously barred by the copyright monopoly, and innovation resulted. Shortening the term of the derivative work right would introduce competition across the entire breadth of the copyright monopoly and fuel innovation throughout the content industries.

\section{G. Implications for Authors}

If copyright policy is to explicitly recognize our human sociability, then authors must forego some currently compensable uses of their works. Authors on average already fare poorly in our market economy. ${ }^{270}$ In the present system a very lucky few win the copyright tournaments and become well rewarded stars. All the rest must eke out modest livings at best or subsidize their creative work with more mundane employment, often giving up creative pursuits in discouragement when mortgages and children impose superseding priorities on their lives. We cannot determine in advance whether the proposed policy changes will burden or benefit authors. While royalty incomes from live performances by others of their musical works might decline for the most successful composers, a far more numerous group of performers would escape the obligatory license fees that live performance of another composer's works requires. More than a redistribution of incomes from composer to performer might result. While copyright benefits authors once they have created works, it burdens them initially by restricting their choices of raw material. Shortening the term of the derivative work right, recalibrates the benefit/burden equation for authors of each prospective work. More and better creations based upon richer and

${ }^{270}$ From 2000-2003 rates of unemployment "for artists were almost twice as high as unemployment rates for all professional workers.” BonNIE NiCHOLS, NAT'L ENDOWMENT FOR THE ARTS, Note No. 87, ARTIST EMPLOYMENT IN 2003, at 2 (2004). " [T] he multiple jobholding rate for artists was more than twice the rate measured for all civilian workers.” Id. at 3 . Artists are less likely than other workers to have full time employment and their incomes are about 83\% of the incomes of professional workers generally. NAT'L ENDOWMENT FOR THE ARTS, REPORT NO. 48, ARTISTS IN THE WORKFORCE 1990-2005, at 19-20 (2008), available at http://www.arts.gov/research/ArtistsInWorkforce.pdf [hereinafter ARTISTS IN THE WORKFORCE]. 
more current sources might revitalize creative culture, leading more consumers to spend a greater share of their incomes on the social experience of copyrighted works, increasing both royalty and live performance incomes. Reforming copyright policy is not necessarily a zero sum game.

Given the marketing, public relations, and lobbying budgets of the copyright industries, it is difficult to maintain a clear distinction in the public debate between the economic health of the copyright industries and that of artists and authors. In an epoch often called the Information Age, when the copyright industries claim a large share of GDP, ${ }^{271}$ the lot of ordinary artists and authors has shown no dramatic improvement. ${ }^{272}$ When the stereotype of the artist starving in a Parisian garret entered our culture, many if not most people experienced real hunger at some point in their lives. In contemporary society this stereotype for artists remains accurate despite our economy's production of a superabundance of material wealth. Despite the explosive growth of the information and entertainment industries and the increasing prominence of the copyright industries, artists still starve while everyone else worries about obesity. ${ }^{273}$

The copyright system is broken, because in an era when the content industries generate a very large share of GDP, artists and authors struggle more than ever. With the exception of the fortunate few whose works enjoy widespread or enduring appeal, the existing system benefits those who reproduce and distribute, not those who create.

\footnotetext{
${ }^{271}$ Core copyright industries (defined as industries whose primary purpose is to exploit copyrighted materials) comprised $6.44 \%$ of U.S. GDP in 2007. Total copyright industries which includes the value-added to related industries by copyright eligible content amounts to 11\% of GDP. Stephen E. Siwek, Economists Inc., Copyright Industries in the U.S. Economy, the 2003-2007 Report 9, 10 (prepared for the Int'l Intellectual Property Alliance (IIPA), 2009), available at www.iipa.com.

${ }^{272}$ Although, artists have higher education levels than the labor force as a whole, they are less likely than other workers to report full-year, full-time employment. Their median income from all sources in 1999 was \$30,000, higher than the median income for all workers of \$25, 300, but lower than the \$36,000 for all professionals. ARTISTS IN THE WORKFORCE, supra note 270, at 19-20.

${ }^{273}$ The health of the general economy may be independent of the condition of the creative community. During the Great Depression when unemployment reached 33 percent and GDP fell by more than 25 percent, the Works Progress Administration's government funded support for the arts gave individual artists secure employment and they reciprocated with a rich artistic legacy that continues to enrich our culture.
} 


\section{The Economics of a Shortened Term for the Derivative Work Right. - If authors}

always must compete against the best of the cumulative past (including their own), then the more of that cultural past that becomes freely available as raw material for future creations, then the better their competitive position with respect to distributors of existing copyrighted content. Authors will have more and better "works" to offer, and distributors will no longer have such an extensive monopoly on derivative works as well.

Extending the full benefit to consumers of a shortened derivative work right depends upon an expansive definition of that right, and as a corollary, a restrictive definition of the reproduction right. ${ }^{274}$ When technological advances create the potential for new formats for existing works, and if new formats fall within the derivative work right, then these become available for distribution by anyone as potential new derivative works. No longer would consumers wait impatiently for content distributors to realize the potential value of their inventory sequestered and forgotten in storage vaults.

Price competition might make it difficult for those creating new derivative works through digitizing existing analogue works to recoup the costs of digitization. Without copyright protection, prices for these works would fall to the marginal costs of reproduction and distribution, which for digital works approaches zero, but since digitalization would support a new copyright, it would consequently become a market barrier for second comers. ${ }^{275}$ Of more concern would be recouping the costs of marketing used to identify new markets or new

\footnotetext{
${ }^{274}$ Compare Lee v. A.R.T. Co., 125 F.3d 580 (7th Cir. 1997) (holding that decorative ceramic tiles created by bonding copyrighted notecard designs onto ceramic slabs without permission are not an infringing derivative work), with Mirage Editions, Inc. v. Albuquerque A.R.T. Co., 856 F.2d 1341 (9th Cir. 1988) (holding that decorative ceramic tiles created by adhering copyrighted art images onto ceramic slabs without permission are an infringing derivative work).

${ }^{275}$ Examples include digitalization of analogue music recordings or film. Whether or not such reformatting should give rise to a new copyright, it could be much shorter than the current term, typically ninety-five years if a work for hire.
} 
distribution techniques, which allow vendors to identify which works have special value to particular buyers (price discrimination is the goal). Once a distributor incurs these marketing costs and identifies a new market, a second competing firm can enter to serve that market without incurring those costs. These same barriers exist for all products unprotected by monopoly grants, and our economy still produces an amazingly wide range of goods. In circumstances when margins are too thin to permit recouping marketing costs, then the reproduction and distribution of such works will be predominantly a noncommercial enterprise, ${ }^{276}$ as with the Google initiative in which it has joined forces with major libraries to make the public domain portions of these libraries' collection available for free over the Internet. ${ }^{277}$ The public gets the works for free through a distribution network that allows the distributor to recoup distribution costs from advertising revenues generated from the medium of distribution, the Internet. The same business model might work for newly available derivative works created by digitizing analogue works after shortening the term of the exclusive right for derivative works.

\section{H. International Consequences}

From the U.S. perspective a drastically shortened term of copyright protection for the derivative work right and a more limited public performance right would place the United States

\footnotetext{
${ }^{276}$ With regard to the Google Book Search, "[t]he Library Project has the potential to be a great boon to scholarship, research, and the public in general. It is, nevertheless, commercial in nature because Google anticipates that it will enhance its service's utilization by the public and concomitantly increase advertising fees.” JEWELER, supra note 235, at 4.

${ }^{277}$ Publishers of works still within copyright have the option of joining this project. See Katie Hafner, Libraries Shun Deals to Place Books on Web, N.Y. TimES, Oct. 22, 2007, at A1 (describing the Open Content Alliance project, which Microsoft and Yahoo joined at its inception in 2005). But see Miguel Helft, Microsoft to Stop Scanning Books, N.Y. TIMES, May 24, 2008, at C8. This project is distinct from the Google Books Library Project, which asserts the right to scan the entire collections of participating libraries, including still protected works, unless the copyright owners affirmatively opt out. See, e.g., MiLLER, supra note 235, at 485-86.
} 
at odds with the rest of the world. The copyright industries contend that American cultural products comprise one of our economy's strongest export sectors, and deviation from their goal of ever strengthening and enlarging the scope of copyright threatens that success. ${ }^{278}$ The 1976 Copyright Act and the 1988 Berne-Implementation Amendments to that Act finally brought the United States largely into conformity with Europe. ${ }^{279}$ At first blush, returning to the outlier status that marked our copyright regime during the previous one hundred years might appear foolish, but if we examine this proposition seriously, it appears far less questionable.

For many decades prior to the enactment of the 1976 Act most of the rest of the developed world required no formalities to obtain copyright protection, and the term of protection for all works extended for the life of the author plus fifty years. ${ }^{280}$ At the time the United States first enacted copyright protection, it produced little in the way of copyrighted works that were of interest to the rest of the world. ${ }^{281}$ For that reason we refused to protect the works of foreign authors, and with few exceptions they were not even eligible for copyright protection. ${ }^{282}$ We relentlessly pirated the works of Charles Dickens and many others. ${ }^{283}$ Until 1978 the works of American authors could only achieve copyright protection under the 1909 Copyright Act, which required publication with copyright notice. Works did not automatically receive protection, and failure to strictly comply with the form, placement, and content of the

\footnotetext{
${ }^{278}$ Foreign sales and exports for the sound recording, motion picture, computer software, and non-software publishing industries rose between 2003 and 2007 from $\$ 95.23$ to 125.6 billion. Siwek, supra note 271, at 16. Of the $\$ 30$ billion in growth, software accounted for $\$ 25$ billion. Industry data substantially exceeds the data of U.S. Bureau of the Census; for motion pictures industry data releases exceed government figures by $40 \%$. Id. at 16 .

${ }^{279}$ The Berne Convention Implementation Act of 1988, Pub. L. No. 100-568, 102 Stat. 2853 (1988).

${ }^{280}$ PAUl GOLDSTEIN, InTERNATIONAL COPYRIGHT 21 (2001).

281، [I]n 1802, there was little ground to anticipate the publication of American works abroad. As late as 1820 Sydney Smith, in the Edinburgh Review, made his famous exclamation, 'In the four quarters of the globe, who reads an American book?’” United Dictionary Co. v. Merriam Co., 208 U.S. 260, 264 (1908).

${ }^{282}$ International Copyright Act of 1891, 26 Stat. 1106; 1909 Copyright Act $\S 9$.

${ }^{283}$ Matthew Pearl, Dickens V America (Apr. 3, 2009), http://moreintelligentlife.com/print/1523 (website of the Economist Magazine). Dickens found his second American lecture tour so lucrative that he made 38,000 pounds from 76 public readings. When "he died a year and a half later, more than $20 \%$ of his estate's assets had come from this American tour.” Id.
} 
copyright notice would irretrievably place the work in the public domain. ${ }^{284}$ After an initial term of twenty-eight years, copyright could be renewed for a further term of twenty-eight years by the filing of a renewal registration, but about eighty-five percent of works initially copyrighted did not have their term renewed. ${ }^{285}$ The average length of copyright protection is estimated to have been about thirty-two years. ${ }^{286}$ Contrast this with automatic protection in Europe, available during that same period, and a term of life plus fifty years. ${ }^{287}$ Yet by 1978 when we conformed to the European system, we had become the copyright superpower of the world. ${ }^{288}$ Our popular culture had swamped the rest of the world. This occurred despite the much higher levels of public spending on the arts found in countries with European cultures. ${ }^{289}$ So, after winning the copyright wars, the U.S. turned around and adopted the system of the vanquished.

But this victory obscures what ought to be the real goal of copyright policy. It is not about comparing gross revenues. There is more than an economic dimension. From the perspective of the rest of the world, especially nations whose copyright industries have yet to entrench themselves as powerful special interests and that have yet to become large exporters of cultural products (films, records, books, etc.), there is no obvious reason to adopt the present U.S. system. That system is principally designed to further augment the revenues of the U.S. copyright industries. Less developed societies should at worst sustain their own nascent

\footnotetext{
${ }^{284}$ NiMMER ON COPYRIGHT, supra note 164, § 7.14[A].

${ }^{285}$ H. COMM., 89TH CONG., SUPPLEMENTARY REGISTER’s REPORT ON THE GENERAL REVISION OF THE U.S. COPYRIGHT LAW 55 (Comm. Print 1965).

${ }^{286}$ See LESSIG, supra note 14, at 24 ("From 1790 until 1978, the average copyright term was never more than thirtytwo years ....”).

${ }^{287}$ The current term is life plus seventy years. Eldred v. Ashcroft, 537 U.S. 186, 193 (2003).

${ }^{288}$ In 2007 the U.S. motion picture and television industry earned \$15 billion from exports of audiovisual services, generating an industry trade surplus of \$13.6 billion. The industry now derives nearly one-half its revenue from outside the U.S. Motion Picture Ass’n of Am., The ECONOMiC IMPACT OF the Motion PiCTURE \& TELEVISION INDUSTRY ON THE UNITED STATES 7 (2009), available at http://www.mpaa.org/EconReportLo.pdf.

${ }^{289}$ In the mid-1990s Germany spent $\$ 85$ per capita while the U.S. spent only \$6. The U.K and France spent \$26 and $\$ 57$ respectively, and Canada spent \$46. NAT’L ENDOWMENT FOR THE ARTS, Note No. 74, INTERNATIONAL DATA ON GOVERNMENT SPENDING ON THE ARTS tbl.1 (2000).
} 
copyright firms, but they would be even better served by designing a system that nourishes and encourages social bonds and the creativity of their authors and artists.

\section{Creation Outside of Copyright}

Advocates of stronger copyright often claim that to create sufficient incentives for innovation, copyright requires a very long term and broad scope, but the historical record contains scant support for this claim. Neither new technologies that create new categories of expressive works, nor the creative revolutions that birth new genres within existing categories, have historically relied upon the copyright monopoly. Innovations have typically originated outside of copyright and developed for some period with an uncertain copyright status before their assimilation within its doctrinal structure. Either the technology innovations did not fit unambiguously within the doctrinal language of copyright, ${ }^{290}$ or the groups or individuals responsible for the innovative genres were too marginal to society to have the resources or sophistication to engage the services of copyright lawyers. ${ }^{291}$ The current expansion of the scope and term of copyright chills creative interaction in public spaces. ${ }^{292}$ Rather than expanding the scope and term of copyright protection, successful incentives for copyright innovation should instead seek to facilitate group social interaction in creative and public environments.

Social groups appear pivotal not just in our subjective enjoyment of expression but also in spurring the creation of new forms of expression. Most, if not all, new forms of American music have emerged from outside the copyright system, evolving out of the hothouse and ferment of intensely collaborative groups akin to minor social movements. ${ }^{293}$ No examples come

\footnotetext{
${ }^{290}$ See discussion infra Part II.J.

${ }^{291}$ See pp. 87-92.

${ }^{292}$ See discussion supra Part II.E. on limiting the public performance and derivative work right.

${ }^{293}$ Social creation is important for technological innovation as well. One disadvantage of universities augmenting
} 
to mind of new musical forms originating from individual geniuses, operating in splendid isolation and sustained by support from major firms in the copyright industries. Instead, a kind of outlaw innovation occurs in socially marginal groups ${ }^{294}$ knit by fluid and dynamic relationships but lacking in hierarchical structure or institutional resources. Innovative artists in these groups use live performance to generate their incomes, often without the benefit of copyright at all.

Some of the most unique and vital contributions to American music have come from the innovations of African Americans operating outside the copyright system. Nearly all the forms of African American music_-spirituals, ragtime, blues, jazz, rhythm and blues, gospel, and hip hop - originated without the benefit of statutory copyright. ${ }^{295}$ Pre-1978, much was never published with notice, a condition of federal protection under the 1909 Act, and much was never even fixed, the essential requirement for protection after $1978 .^{296}$

Blues, spirituals, and even traditional jazz, which originated in New Orleans in the first decades of the twentieth century, developed without the benefit of copyright because many compositions were never notated as sheet music and published with the requisite notice. ${ }^{297}$ Unknown authors crafted many works, and others resulted from collaborative efforts developed over time. Few would or could have been published with notice in the ante bellum South or the

their funding by patenting and licensing research discoveries is the chilling effect that seeking to protect potentially valuable property rights has on communication and collaboration in the scientific community. A similar concern drives the Open Source Software movement, which seeks to dedicate to the public domain and communal collaboration software that would otherwise be fully protected by patents and copyright. See Jacobsen v. Katzer, 535 F.3d 1373 (Fed. Cir. 2008).

${ }^{294}$ Marginality may be due to age, race, ethnicity, poverty, geographic isolation, and social norms and/or practices. ${ }^{295} 1909$ Copyright Act $\S 10$.

29617 U.S.C. §102(a) (2006).

${ }^{297}$ See KenNEY, supra note 108, at 1, 43-44 ("The year 1916 was a good year for the pianist and bandleader [Fate Marable].... [H]is first and only published composition appeared that year.”). 
post Reconstruction era of the Black Codes. ${ }^{298}$ The development of the older music forms, the blues and spirituals, occurred before the 1897 amendment, which added public performance rights to the bundle of property rights comprising copyright. ${ }^{299}$ Many musicians in these early genres lacked much beyond the rudiments of formal training, and their appreciative publics probably had even less. Since prior to recording technology and the grant of public performance rights to musical works, sales of sheet music were the only lucrative form of commercial exploitation of copyrighted music, there was little incentive to even pursue copyright. Live performance generated income for these musical artists. (Ragtime was the exception. Sheet music sales were important to ragtime’s creators, and its major innovators were relatively well schooled. ${ }^{300}$ )

The critical core of jazz has always been improvisation. Improvised music, as an unnotated musical performance, could not satisfy the requirements of the 1909 Act. Even the 1976 Act’s fixation requirement for copyright protection would have necessitated the recording of improvised performances to achieve copyright protection, and recording live performances was considerably more expensive and technically challenging in the days before the transistor led to the progressive miniaturization of the essential equipment. ${ }^{301}$ The birth of bebop, which transformed jazz from the dominant popular dance music (“swing”) to a less popular and more cerebral “art” music, occurred during World War II when a recording strike by musicians and a wartime shortage of the material used to produce records created a two year hiatus in the

\footnotetext{
${ }^{298}$ See GunNar Myrdal, The AMERICAN Dilemma 128-29 (1944).

${ }^{299}$ See Act of Jan. 6, 1897, ch. 4, § 4966, 29 Stat. 481, 481-82 (current version at 17 U.S.C. § 106(4) (2006)).

300 "Although ragtime was primarily a written genre ....” NEW GROVE DiCTIONARY OF JAZZ 1013 (Barry Kernfeld ed., 1994) (defining "ragtime”); “composed and notated,” id. at 1014.

${ }^{301}$ The most common source of nonstudio recorded jazz recordings are "air checks," acetate recordings made of jazz groups performing live radio broadcasts. These were not limited to the three to four minutes of recording time imposed by the $78 \mathrm{rpm}$ format. "In the 1930s and 1940s broadcast transcriptions were recorded on 16-inch discs that played at 33 1/3 r.p.m., allowing up to 15 minutes of playing time ....” NEW Grove DictionARY OF JAzZ, supra note 300, at 1215 (defining “Transcription”(iii)).
} 
recorded evidence of jazz. ${ }^{302}$ The resulting dearth of transitional material creates the impression of almost instantaneous change, with bebop seemingly emerging almost in its mature form. Relying only on the evidence of recordings, "swing" dominated the musical charts going into the war, but immediately following the war's end, a newer form, bebop, with its more complex rhythms and chromatic harmonies, eclipsed it. ${ }^{303}$ Bebop actually developed less discontinuously than the evidence found in recorded sources, but it did develop outside the copyright system.

During the war time hiatus in recording, bebop developed in jam sessions at after-hours clubs in New York City and in the experiments in sections of touring swing bands led by the more adventurous leaders, most notably Billy Eckstine. ${ }^{304}$ In Harlem a legitimate night club, Minton's Playhouse, played a seminal role. ${ }^{305}$ Jam sessions, first popularized during the swing era, often consisted of improvised performances of both original and standard popular song compositions. ${ }^{306}$ These performances would have required licenses from performing rights organizations (PROs) if considered public performances for profit. ${ }^{307}$ Since after hours clubs operated illegally - after the closing times established by local ordinances - so they were not completely open to the public, but they were also not open to just those customers within the

\footnotetext{
302 See Scott DeVeaux, The Birth of Bebop: A Social AND Musical History 15, 239-40, 295-99 (1997).

${ }^{303}$ See id. at 318-19.

${ }^{304}$ See id. at 201; see also id. at 318-63 (detailing the Billy Eckstine band's "peculiar position in the genesis of bebop"). Many of the key innovators toured as part of the Billy Eckstine band. When in New York they frequented these afterhours haunts. Some of the most noteworthy innovators were Charlie Parker, Dizzy Gillespie, Thelonius Monk, Max Roach, Kenny Clarke, and Bud Powell. See id.

${ }^{305}$ See id. at 201, 219-20. See also NeW Grove DictionARY OF JAZZ, supra note 300, at 898 (entry for “Minton's Playhouse"). "Minton's Playhouse 210 West $118^{\text {th }}$ Street. It was opened in 1938 by the tenor saxophonist Henry Minton. In 1940 the club’s management was taken over by the former bandleader Teddy Hill . .., who concentrated much of his energy on the regular Monday-night jam sessions, in which visiting musicians took part; among the guest performers who played there often were Dizzy Gillespie, Hot Lips Page, Roy Eldridge, Charlie Christian, and Don Byas. The resident musicians included Thelonious Monk (from 1939), Kenny Clarke, Joe Guy (who led the house band), and Rudy Williams (1945). The weekly jam session and after-hours playing at Minton's provided an opportunity for musicians such as Gillespie and Monk to explore new ideas together, and their experiments played an important part in the development of bop ....”

306 “Jam. To improvise, usually in a group, whence to take part in a Jam Session.” NEW Grove DictionARY OF JAzZ, supra note 300, at 575 (defining “Jam”).

3071909 Act $\S 1$ e.
} 
normal circle of a family and its social acquaintances. ${ }^{308}$ Assuming these performances were public and therefore infringing public performances, one might question whether operators of illegal after-hours clubs would have bothered obtaining the requisite performance licenses to comply with the Copyright Act. The same could be said of the many speakeasies operated during Prohibition during the heyday of traditional jazz. Even with performance licenses, improvisation at least arguably creates unauthorized derivative works (assuming such works need not be fixed), ${ }^{309}$ and these creations would lie outside the scope of public performance licenses granted by PROs. ${ }^{310}$

Jazz in all its many forms — traditional, swing, bebop, and the "new thing”- -has evolved in unpredictable paths without central guidance or any concern for the regime of copyright. Individual contributions have been so amorphous that no one individual can claim sole responsibility for any particular school or genre of American music. To be sure, creative giants made seminal contributions, but at the inception of each innovation copyright played an insignificant role. Innovators themselves did much of the work of bringing new forms to mass audiences through constant touring throughout the country. ${ }^{311}$ For original jazz compositions, published as sheet music with appropriate notice, copyright protected the musical work. But for the much larger number of recordings of jazz performance based upon "standards” initially written for Broadway, Tin Pan Alley, or the “Pop” market, federal copyright protected only the underlying musical work, which typically comprised only a small portion of the recorded

\footnotetext{
${ }^{308}$ See supra note 236 and accompanying text.

${ }^{309}$ See supra notes 247-253 and accompanying text.

${ }^{310}$ Given the murky boundaries surrounding the derivative work right, jazz improvisation, which is unpredictable in its range and scope, presents an analytical problem for the system of performance licensing developed by the PROs. Provided all concerned treat unfixed derivative works as within the public performance license under current law, the practical significance of this problem can be overlooked.

${ }^{311}$ For the story of Riverboat jazz' role in the evolution of traditional jazz, see generally KENNEY, supra note 108. See also DEVEAUX, supra note 302.
} 
performance, often well below fifteen percent. ${ }^{312}$ Even in the subsequent reproduction and distribution of the best selling sound recording by major record labels, federal copyright played a diminished role prior to 1972. Under the 1909 Act, sound recordings published (via distribution) with the appropriate notice came within its compass only with the 1971 enactment of the Sound Recording Act. ${ }^{313}$ Prior to that time they were protected, if at all, by state common law. ${ }^{314}$

The contemporary situation regarding innovation differs little. Copyright still plays an insignificant role in innovation, as the evolution of hip hop demonstrates. The overwhelming use of digital samples by this genre presented a thorny legal and business problem from its inception. Performers embedded short snippets of earlier recordings, looped them (repeated replays), and sometimes electronically manipulated them (often obscuring their origin). ${ }^{315}$ Whether this practice constituted fair use or infringing appropriation has yet to be definitively resolved. ${ }^{316}$ At least one circuit court of appeals has foreclosed any de minimus use of samples and rejected the substantial similarity test, effectively barring any unlicensed sampling from a sound recording. ${ }^{317}$ Despite its questionable legal status, the practice of sampling has in the last decade evolved sufficient licensing arrangements to permit this peculiar method of music production to thrive. ${ }^{318}$ In an ironic twist, hip hop, a music form that limits the participation of live instrumental musicians in much of its creation and relies instead on electronic manipulation of usually brief

\footnotetext{
${ }^{312}$ For a theoretical computation reaching fourteen percent, and a specific example (by no means extreme) in which the recognizable theme of the composition comprised only sixty-four seconds of an eleven minute, thirty-one second performance, see Note, Jazz Has Got Copyright Law and That Ain't Good, 118 HARV. L. REV. 1940, 1943-44 (2005).

${ }^{313}$ Act of Oct. 15, 1971, Pub. L. No. 92-140, 85 Stat. 391 (codified as amended in scattered sections of 17 U.S.C.).

${ }^{314}$ See 1 NiMMER ON COPYRIGHT, supra note 164, § 4.06[B] (2006).

${ }^{315}$ M. William KRASILOVSKY \& SYdney Shelmel, This BusinesS OF Music 197-98 (9th ed. 2003).

${ }^{316}$ NIMMER ON COPYRIGHT, supra note 164, § 13.03[A][2][b].

${ }^{317}$ Bridgeport Music, Inc. v. Dimension Films, 410 F.3d 792, 800-02 (6th Cir. 2005) ("If you cannot pirate the whole sound recording, can you 'lift' or 'sample' something less than the whole. Our answer to that question is in the negative." (citation omitted)).

${ }^{318}$ KRASILOVSKY \& SHELMEL, supra note 315, at 197-200.
} 
excerpts from existing recordings for its source material, (and earlier in the analogue era on physical manipulation of turntables by disc jockeys) has restored some of the audience performer interaction. ${ }^{319}$ Only in this instance the disc jockey has become the performer. Ordinary (nonhip hop) DJs in dance clubs select and play recorded music to match or manipulate the mood of dancers (or entice wallflowers onto the floor), a functional role that poorly substitutes for the interaction between dancers and live musicians that existed when live music was the only music. When a disc jockey merely plays recordings, his actions fall within the nonexclusive license granted by performing rights organizations for the public performance of their catalogue of musical works. ${ }^{320}$ The hip hop disc jockey goes beyond mere selection and instead "plays” turntables (called "scratching”) ${ }^{321}$ almost as if they were musical instruments. He (or she) uses manual or electronic manipulation of his turntable (or CD player) to repeat various sections of music or introduce extraneous or additional sounds or musical segments by using a second turntable (or CD player), while simultaneously “rapping” over the sounds created. ${ }^{322}$ This development of the creative manipulation of turntables—scratching —into another medium of expression restores some of the live performer audience interaction that disappeared when recordings replaced live bands.

This innovation also developed outside of copyright. The practice itself, even if not outside the scope of the public performance license, would infringe the derivative work right provided courts held that such infringement would not require fixation of the derivative work, a

\footnotetext{
319 See generally Yes Yes Y’All, The ExPERIEnCE Music Project Oral History Of Hip-Hop’s First DeCADE 69-133 (2002). "The MCs [master of ceremonies/rapper] begin to involve the whole audience in the party.” Id. at 69.

${ }_{321}^{320}$ NIMMER ON COPYRIGHT, supra note 164, § 8.19[A].

322
} 
contentious issue. ${ }^{323}$ If it does infringe, but nonetheless goes undetected or unsanctioned, then no copyright protection exists for the new work, because for a work employing preexisting material in which copyright subsists, no copyright protection extends "to any part of the work in which such material has been used unlawfully. ${ }^{\text {324 }}$ Alternatively, if it does not infringe because the derivative work remains unfixed, then the new potential derivative work remains ineligible for copyright protection, because fixation is an essential prerequisite for protection. ${ }^{325}$

By the time the genre had progressed to the stage that these turntable manipulations of "samples" and rapping were recorded, copyright doctrine still could not easily assimilate the musical result. Hip-hop, with its unconstrained sampling, challenged copyright's conceptions not only of derivative works, but of fair use and substantial similarity as well. How small a sample would still infringe the reproduction right because it is "substantially similar?" How recognizable must it be? When would the manipulation of a sample be a fair use of the original material? These questions remain largely unanswered. ${ }^{326}$

Popular music genres are not the only forms of entertainment and culture to develop outside of copyright. Stand up comedy has grown over the last several decades, especially as a form of live entertainment. ${ }^{327}$ Jokes performed by stand up comedians have never been part of the copyright system:

Although there is very little authority on the question, it would seem that jokes, "gags" and other forms of "stage business" may claim copyright protection. This assumes originality, which in the case of jokes or "gags" will often be a most doubtful element. Such protection is, of course, limited to the "expression" and not the mere "idea." As the value of a joke, etc.,

323

32417 U.S.C. $\S 103(\mathrm{a})(2006)$.

325 See id. § 102(a).

${ }^{326}$ But see Bridgeport Music, Inc. v. Dimension Films, 410 F.3d 792, 796, 800-02 (6th Cir. 2005), which held even a thoroughly manipulated, two second excerpt infringing. This decision has been heavily criticized by copyright scholars. See, e.g., 4 NiMMER ON COPYRIGHT, supra note 164, § 13.03[A][2][b] (2008). 
often lies in its idea rather than its particular expression, this serves to severely limit the value of such copyright. ${ }^{328}$

All comedians steal from each other. The timing, delivery, vocal nuances, and stage persona of comics combine with the idea to create the comedy more than the particular words chosen to convey the jokes or humorous observation. The comic ideas are beyond the scope of copyright protection. ${ }^{329}$ And the expression must be tailored to the particular personality and comic style of individual performers, so the role of copyright is necessarily limited. Yet stand up comedy is thriving in all our major cities.

Just like the innovations of African American musicians, whose recordings, as reproduced and distributed by the major record labels, generate enormous revenues (protected by copyright) for the major record labels, these stand-up comedians have provided the raw material and personnel for many of the most lucrative television shows of our era; and copyright protects these shows. From Jack Benny and Jackie Gleason, and Redd Fox to Bill Cosby, Jerry Seinfeld, and Raymond Romano, the performers originate and develop their routines in live comedy outside the copyright economy and support themselves from the revenues produced by live performances in which interaction with a live audience is a critical part of both their development as performers and their comedy. The late, great Johnny Carson was never so funny as when he ad libbed to play off the (apparent) flop of a joke with the studio audience.

Social dancing is another significant cultural and expressive activity to develop outside

\footnotetext{
${ }^{328} 1$ NimMER ON COPYRIGHT, supra note 164, § 2.13 (2008) (citations omitted). See also Allen D. Madison, The Uncopyrightability of Jokes, 35 SAN DiEGo L. REV. 111 (1998); Gayle Herman, Note, The Copyrightability of Jokes: “Take My Registration Deposit . . Please!”, 6 CommENT L.J. 391 (1983).

${ }^{329}$ See 17 U.S.C. § 102(b) (2006). Compare Guedes v. Martinez, 131 F. Supp. 2 d 272 (D.P.R. 2001) (holding analogue broadcast of comedian's copyrighted compact disc does not infringe copyright in sound recording of comedic routine absent any copyright in the underlying compositions (jokes) because there is no exclusive right to public performance of sound recordings except by digital audio transmission), with Foxworthy v. Custom Tees, Inc., 879 F. Supp. 1200 (N.D. Ga. 1995) (granting preliminary injunctive relief to comedian on copyright protection claim for jokes that "were not only his own ideas, but his own expression," which defendant had replicated and sold on t-shirts).
} 
the copyright system. Unlike ballet and other choreographed dance forms, which are explicitly within the scope of copyright protection, ${ }^{330}$ the legislative history of the 1976 Act states that ““choreographic works’ do not include social dance steps and simple routines.”331 Thus popular dance forms from the Charleston and Lindsey, to the jitterbug, the twist, break dancing, and now krumping, ${ }^{332}$ arose outside of copyright. Social dancing has lost much significance, perhaps because of the decline of live music performance. In the first decades of the last century in Chicago, social dancing involved nearly 90,000 people attending dance halls every evening, more than any other form of recreation. ${ }^{333}$

Other examples of creative activities include entire industries outside the scope of copyright, some of which have long and continuous records of creative innovation. These include fashion, food preparation, hair styling, perfumes, ${ }^{334}$ and open source software. As Raustiala and Sprigman point out, the fashion industry is far "larger than those for movies, books, music, and most scientific innovations ....”335 The fashion industry in particular involves very large investments, and aside from occasional attempts to control piracy, it has not made a concerted or persistent effort to obtain legislative amendments extending copyright protection to fashion designs. ${ }^{336}$ These scholars also make the stronger claim that the absence of

\footnotetext{
${ }^{330} 17$ U.S.C. § 102(a)(4) (2006) (“Copyright protection subsists . . . in original works of authorship fixed in any tangible medium of expression .... Works of authorship include ... pantomimes and choreographic works ....”). See also id. § 106(4).

${ }^{331}$ H.R. REP. No. 94-1476, at 54 (1976), as reprinted in 1976 U.S.C.C.A.N. 5659, 5667. See also 1 NIMMER ON COPYRIGHT, supra note 164, § 2.07[B] (1998).

${ }^{332}$ See, e.g., Krumping, http://en.wikipedia.org/wiki/Krumping (last visited Aug. 29, 2008).

${ }^{333}$ See supra note 107 and accompanying text.

${ }^{334}$ But see Thomas G. Field, Jr., Copyright Protection for Perfumes, 45 IDEA 19 (2004) (examining the Dutch Appeals Court's opinion upholding copyright protection in perfume compositions).

${ }^{335}$ Kal Raustiala \& Christopher Sprigman, The Piracy Paradox: Innovation and Intellectual Property in Fashion Design, 92 VA. L. REV. 1687, 1689 (2006) (citations omitted).

${ }^{336}$ In the 2007 legislative session as in the previous one, bills were introduced to extend design protection to fashion designs. See, e.g., Design Piracy Prohibition Act, S. 1957, 110th Cong. (2007).
} 
copyright protection, rather than destroying innovation, may actually have promoted it. ${ }^{337}$

While the availability of copyright protection plays little role in creative innovation, copyright does provide significant incentives for the reproduction and distribution of innovative works, even those produced outside of its system. But the twin recent developments of the Internet and digitalization have greatly diminished the role played by copyright protection. These twin developments have reduced to nearly nothing the costs of reproduction and distribution for digital works. For such works only marketing costs continue to justify copyright's burdensome monopoly grant.

While nearly eliminating the economic resources needed to reproduce and distribute digital works, digitalization and the Internet have also dramatically increased the importance of marketing. With the entire world's contemporary and historic culture at our fingertips, we risk burial in a blizzard of information and choices. Astute marketing, conceived as something beyond merely manipulating consumer tastes to create blockbuster hits, would provide an invaluable service if it helped us make rewarding selections from the nearly infinite choices the Internet makes available. This alone would justify at least some monopoly burden. But marketing that cynically overwhelms our consciousness with ubiquitous messages intended to crowd out other choices creates too few benefits to offset the burden of the monopoly grant.

\section{J. New Outlaw Technologies of Creation}

Authors have used many new technologies to create works with dubious copyright status. Neither the motion picture nor the radio industry developed under the protective umbrella of the copyright monopoly. Both arose after the passage of the 1909 Act, which contemplated

337 See Raustiala \& Sprigman, supra note 335, at 1732-34, 1775-77. 
neither. ${ }^{338}$ At that time copyright required publication of copies with the appropriate notice for federal copyright to vest, ${ }^{339}$ and neither innovation fit within existing frameworks. Theatrical exhibition of motion pictures was not clearly publication with notice, and live radio broadcasts produced no copies. Radio music broadcasts, whether of live bands or of recordings, was not clearly within the copyright monopoly. Not until successful litigation sponsored by ASCAP was it established that radio broadcasts of recordings infringed the public performance right in the underlying musical compositions. ${ }^{340}$ At the time, commercial bands considered airplay, which often intensified for particular bands upon their imminent arrival in a locality, as valuable advertising designed to generate audiences for their live performances. ${ }^{341}$

Even television, a technological advance developed in part by firms with substantial presences in radio broadcasting (although at a later time when copyright had comfortably encompassed radio), began outside of copyright. ${ }^{342}$ Initially television broadcast its original content live. (It also broadcast preexisting content, consisting of old movies or cartoons, but these had been previously copyrighted.) Live broadcasts produced no copies (unlike movie distribution) and were thus outside the scope of federal copyright. Cable television began as a subscription service, providing customers the passive reception of marginal broadcast signals for remote communities often in mountainous regions, and only later evolved as a source of original content. ${ }^{343}$ Only then did its operations come to depend upon revenues generated by the copyright monopoly.

\footnotetext{
${ }^{338}$ LITMAN, supra note 14 , at 48.

${ }^{339} 1909$ Copyright Act $\S 10$.

340 Jerome H. Remick \& Co. v. Am. Auto. Accessories Co., 5 F.2d 411 (6th Cir. 1925), cert. denied, 269 U.S. 556 (1925); M. Witmark \& Sons v. L. Bamberger \& Co., 291 F. 776 (D.N.J. 1923).

${ }^{341}$ See DeVeauX, supra note 302, at 366.

${ }^{342}$ See Litman, supra note 176, at 305 (describing the history of the revision effort for the 1909 Act as based upon criticism of an "outmoded" act that "had, after all, been drawn to accommodate the requirements of particular media before the advent of radio, jukeboxes, sound motion pictures, Muzak ${ }^{\circledR}$, and now television”).

${ }^{343}$ See the fact pattern in Fortnightly Corp. v. United Artists Television, Inc., 392 U.S. 390 (1968).
} 
Casual photocopying remains outside of copyright as a practical matter except to the extent it is viewed as a mechanism of systematic infringement by commercial firms. ${ }^{344}$ Computer software, originally developed as proprietary to particular hardware, was tied to the purchase of, and would only run on, computers manufactured by particular firms. ${ }^{345}$ Until the Copyright Act was amended, it was contested whether computer programs were even within the scope of copyright, given their functional elements. ${ }^{346}$ Even now the commercial life of computer software is only a few years, while the term of protection lasts nearly a century, ${ }^{347}$ hardly a justifiable result.

We have more than historical examples to guide us. Current innovations, from blogging and search engines to YouTube, have developed as significant businesses, and only after these phenomena reached a certain level of maturity did their operators settle on business models and sources of revenues (advertising). ${ }^{348}$ Exactly how copyright interfaces with these innovations have generated vigorous debates within the legal community and the courts have yet to resolve a myriad of issues.

The history of innovation in expressive works does not justify the extreme length and breadth of the modern copyright statute. Reducing its length or breadth poses no catastrophic risks to our cultural life. But failing to respond to the changes technology has created in the ways we experience works poses potentially unacceptable risks.

\footnotetext{
${ }^{344}$ Williams \& Wilkins Co. v. United States, 487 F.2d 1345 (Ct. Claims 1973), aff'd by an equally divided court, 420 U.S. 376 (1975) (construing the 1909 Act); Princeton Univ. Press v. Mich. Document Servs., Inc., 99 F.3d 1381 (6th Cir. 1996) (en banc), cert. denied, 520 U.S. 1156 (1997).

${ }^{345}$ Final Report of the National Commission on New Technological Uses of Copyrighted Works (1978).

${ }^{346}$ GORMAN \& GinSBURG, supra note 14, at 181 (Copyright Office “Rule of Doubt”); H. ReP. to 1976 Act § 102.

${ }^{347}$ For works for hire the term of protection is the shorter of 95 years from first publication or 120 years from creation. 17 U.S.C. § 302(c) (2006).

${ }^{348}$ Social networking and user generated content sites are typical examples.
} 


\section{CONCLUSION}

The current rapid pace of social and technological change has no precedent in our evolutionary history. To the extent that expressive culture helps us cope with change by enhancing social bonds, we need it now more than ever, yet the ever increasing term and scope of copyright protection limits more and more our access to this vital social resource as material with which to reinterpret our experiences and perspectives. Technology and the Copyright Act have combined to fundamentally change the way we experience expressive culture, changing it from a communal and social experience to an individual and atomistic one. Given the possible evolutionary purposes served by this expressive culture, such a transition may pose significant if unknown challenges to our species. We would be well advised to reexamine the need and consequences of such drastic changes to a cultural phenomenon whose pervasive presence in all human societies and throughout our entire history suggests it plays a vital role in our societies and the ties that bind us.

The proposed revisions to the Copyright Act in Part II would work the fundamental change of restoring some of the social experience to our expressive culture. They would also partially return us to the historic norm of more immediate access to our cultural past. We currently view our copyright polices as a subset of economic policies, but expressive culture is not primarily an economic phenomenon. It is a social one. Reforming copyright policy to reflect this major reorientation would not entail a wholesale revision of the statute. Instead, rather modest changes would reverse our headlong but unthinking pursuit of an increasingly atomized and isolated experience of our culture. Exempting live performance of musical works from the public performance right, shortening the term of copyright for the derivative work right, and requiring fixation to infringe the derivative work right would accomplish much in restoring 
social aspects to our consumption and creation of expressive culture.

These revisions would significantly change the copyright industries. Presently, current authors must compete against our entire culture's recorded past, including their own previous work. And nothing produced by others within their lifetimes is freely available to serve as raw material for their new creations. ${ }^{349}$ The proposed changes in the Act would enhance the competitive position of current authors vis a vis the distributors of content and counteract the "winner take all” nature of copyright markets. By enabling the social creation of expressive works, these changes would also allow the kind of creative interchange the existing statute prohibits.

The proposed reorientation of copyright policy toward facilitating the social experience and creation of expressive culture also creates a touchstone for judicial interpretation of the Act. The continuing emergence of new technologies and business models strains the doctrinal concepts and technologically based exemptions of the Act. As others have demonstrated, the 1976 Act resulted from a series of interrelated compromises among the major interests in the copyright industries. ${ }^{350}$ It achieved this compromise by expanding the copyright pie—ensuring that all participants would receive more-by, for the first time, expressing the scope of copyright's exclusive grants in unqualified and all inclusive terms. ${ }^{351}$ It also coupled those broad grants with narrow and technologically specific exemptions and privileges ${ }^{352}$ which, as technology develops, have rapidly become obsolete. Since, aside from the desire to enact the negotiated web of compromises between and among the affected copyright industries, no general

\footnotetext{
${ }^{349}$ Any works produced since 1964 under the 1909 Act remain protected by copyright for a term of 95 years because the 1992 amendments provided for automatic renewal of 1909 Act works, preventing works for which no timely renewal application was filed from entering the public domain. 17 U.S.C. § 304(a)(2)(A) (2006).

${ }^{350}$ See, e.g., Litman, supra note 176, at 281, 311-32.

${ }^{351}$ See id. at 281, 317-23.

${ }^{352} \mathrm{Id}$.
} 
statutory purpose animated the Act, courts have had no reference points to guide them when called upon to interpret ambiguous language. ${ }^{353}$ Identifying a purpose outside the economic interests of affected industries provides, in some small measure, such guidance.

Once we meet the minimums of food and shelter the quality of our social relationships determines the quality of our lives. A loving family and good friends provide contentment to nearly anyone, as well as measurable health benefits. Immense wealth and power without anyone to care about brings little satisfaction. Expressive culture probably exists because of the role it plays in forming or cementing social ties. Our current statute has been tailored for the rational economic man, but it seems wiser to reconsider this standard and instead reorient the Copyright Act to facilitate the social lives of a social species.

${ }^{353}$ See id. at 315-16. 